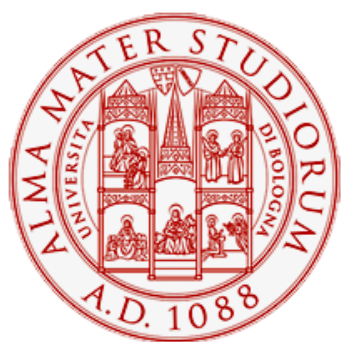

Alma Mater Studiorum - Università di Bologna DEPARTMENT OF ECONOMICS

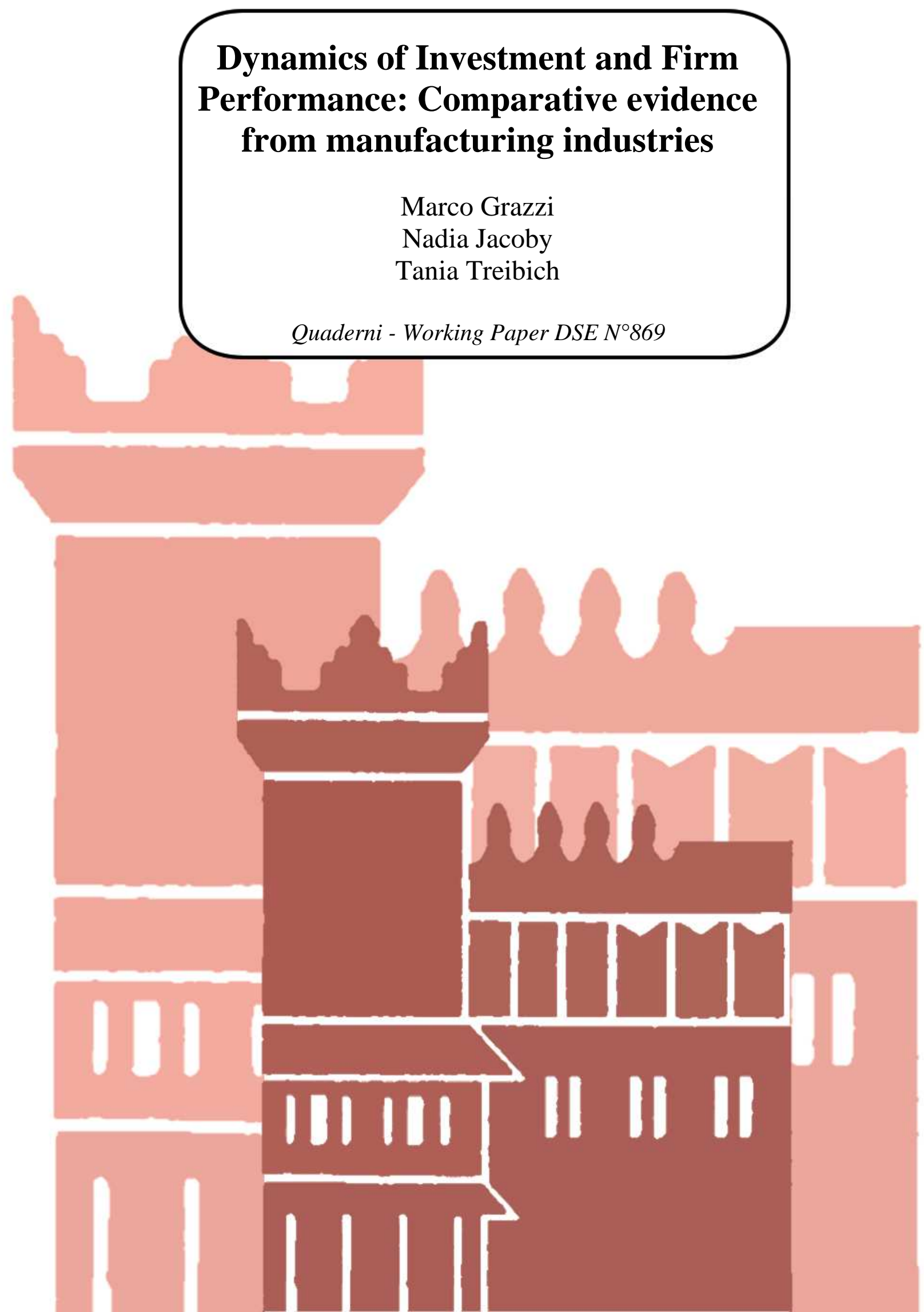




\title{
Dynamics of Investment and Firm Performance: Comparative evidence from manufacturing industries*
}

\author{
Marco Grazzi ${ }^{\dagger}$ \\ University of Bologna - Department of Economics
}

Nadia Jacoby ${ }^{\ddagger}$

University of Paris 1 Panthéon-Sorbonne-Centre d'Économie de la Sorbonne

\author{
Tania Treibich ${ }^{\S}$ \\ OFCE/DRIC; GREDEG, University of Nice-Sophia Antipolis, Nice, France and SKEMA \\ Business School
}

February 12, 2013

\begin{abstract}
If the relation between investment and economic growth is well established in the macroeconomic literature, the existence of a similar link at the level of the firm has been challenged by empirical work. This paper investigates the channels linking investment and firm performance in the French and Italian manufacturing industries. It does so by putting forth a novel methodology to identify investment spikes that corrects for size dependence. While maintaining the desired properties of a spike measure, our chosen proxy retrieves the expected relation between investment and firm performance. Ex-ante, more efficient and fast growing firms display a higher probability to invest; in turn, after an investment spike has taken place the group of investing firms shows further gains in performance. Finally, expansionary investment episodes, as proxied by the opening of new plants, have a negative effect on profitability while they are associated with higher sales and employment levels.
\end{abstract}

JEL codes: C14, D22, D24, D92, E22, L11, L23, L60

Keywords: Firm heterogeneity, investment spike, industrial dynamics, corporate performance, capital accumulation, technical change.

\footnotetext{
${ }^{*}$ We thank Giulio Bottazzi, Giovanni Dosi, Angelo Secchi and Federico Tamagni for many useful discussions and comments at various stages of this work. We benefited from the comments of several participants in the conferences EARIE 2011, Stockholm, SIE 2011 Rome, CAED 2012 Nuremberg, University of Nice-Sophia Antipolis and University of Paris. The statistical exercises which follow would not have been possible without the valuable help of the Italian Statistical Office (ISTAT), in particular of Roberto Monducci, and of the French Statistical Office (INSEE). Authors acknowledge financial support from the European Commission 7th Framework Programme (FP7/2007-2013) under Socioeconomic Sciences and Humanities, FINNOV grant agreement n. 217466 and from the Institute for New Economic Thinking, INET inaugural grant 220. The usual disclaimer applies.

${ }^{\dagger}$ Department of Economics, Piazza Scaravilli 2, 40126 Bologna, Italy. tel: +39-051-2098130, email: marco.grazzi@unibo.it

${ }^{\ddagger}$ CES - Centre d'économie de la Sorbonne Maison des Sciences Économiques 106-112 Boulevard de l’hôpital F-75647 Paris cedex 13 tel: +: +33-1-44078145, email: jacoby@univ-paris1.fr

${ }^{\S}$ GREDEG, 250 rue Albert Einstein - Bat.2, 06560 Valbonne, France, tel: +33-4-93954230, email: tania.treibich@gmail.com
} 


\section{Introduction}

In this paper we investigate the relation between firms' investment in tangible assets and corporate performance. If at the macroeconomic level equipment investment is associated with economic growth (De Long and Summers, 1991), the idiosyncratic impact of firms' investment on their ability to grow or to increase their efficiency has not been asserted. Moreover, firms' decisions to pursue large investment projects and their timing are also related to managers' expectations of future business opportunities and to the phases of the cycle. In this respect, Gourio and Kashyap (2007) have indeed shown that the bulk of variation in aggregate investment is explained by changes in the number of establishments undergoing investment episodes (the "extensive margin"). ${ }^{1}$ It is then apparent that in order to interpret changes in aggregate investment, as well as how those changes relate to economic growth, it is much relevant to gain a thorough understanding of the heterogeneous behavior occurring at the firm level. It will be on the latter that the paper will focus upon.

Assessing the impact of investment at the level of the firm has not always been a viable research question. For long, the impossibility to access observed investment data has hindered empirical research on the issue. It was indeed only in recent years that scholars have started to document the nature of the investment behavior of firms. Among the first attempts in this direction is the contribution by Doms and Dunne (1998) with data on U.S. plants and firms. Inspired by this seminal paper a growing body of literature has expanded reporting similar results for other countries and industries. ${ }^{2}$ A common finding shared by these studies is the lumpy nature of firm-level investment: years of inactivity or repair and maintenance are followed by year(s) in which investments are large both with respect to the firm and the industry as a whole. As for instance shown in Carlsson and Laséen (2005) non-convex adjustment cost models provide a more appropriate framework for explaining investment decisions, thus rejecting the ones which assume a smooth pattern of capital accumulation. More generally, investment irreversibility due to the idiosyncratic nature of the capital purchase as well as the indivisibility of physical capital also explain the observed lumpiness of investment rates both at the plant and at the firm level.

As a rather straightforward consequence, carrying out unusually large investment projects requires a corresponding effort in terms of financial commitment. If the internally generated resources do not suffice, the firm has to rely also on external finance to realize its investment projects. In this framework, two possible outcomes are associated with such dependence on external financing. First, investment activity might be limited if firms are financially constrained, see among the others Schiantarelli (1996); Audretsch and Elston (2002); Whited (2006). That is, the desired level of investment for a firm is curbed (set to zero) because of the insufficient (complete lack of) access to external finance. Second, to the extent that investments are associated with firm growth, ${ }^{3}$ the existence of financial constraints would also preclude firms the possibility to exploit growth opportunities. If this were the case, the limited access to external finance would constrain firm growth through the channel of insufficient investment. In this respect, the present study also contributes to the literature on financial constraints to firm growth (see, among the others Oliveira and Fortunato, 2006; Whited, 2006; Angelini and Generale, 2008; Bottazzi et al., forthcoming).

A growing stream of literature has indeed started to investigate the relationship between capital adjustment episodes and firm level (performance) characteristics, such as productivity ${ }^{4}$ and its growth rate (Power, 1998; Bessen, 1999; Huggett and Ospina, 2001; Nilsen et al., 2009; Shima, 2010), employment growth (Asphjell et al., 2010), sales growth (Licandro et al., 2004) or other factors of production (Sakellaris, 2004; Nilsen et al., 2009). In particular, investment should affect productivity in the long run, as new capital embodies the latest technology (Jensen et al., 2001). "Learning by doing" models anticipate that it should take some time for workers to learn using the new technology, therefore after

\footnotetext{
${ }^{1}$ The authors indeed focus on investment "spikes": as we extensively discuss below, significantly large investment episodes are rare at the firm level.

${ }^{2}$ Among the papers using a comparable methodology to Doms and Dunne (1998), the reader might refer to Duhautois and Jamet (2001) for France, Nilsen and Schiantarelli (2003) and Nilsen et al. (2009) for Norway and Carlsson and Laséen (2005) for Sweden.

${ }^{3}$ Firm growth being considered either in terms of sales or employment.

${ }^{4}$ Either labor productivity or total factor productivity is considered. The former was used by Power (1998), Bessen (1999), and Nilsen et al. (2009), as we do here, while the latter by Huggett and Ospina (2001) as well as Shima (2010).
} 
an investment episode labor productivity might follow a $U$ shape curve, initially dropping and then gradually rising to a higher level. Most of the empirical literature on the subject (Power, 1998; Huggett and Ospina, 2001; Sakellaris, 2004; Shima, 2010) reports that the effect of investment spikes on productivity growth is indeed negative in the short run. If the initial cost has been uncovered by most of these studies, none of them report a positive relation between investment lumps and productivity growth, even in the long run. ${ }^{5}$ The lack of a positive relation between investment in tangible assets and productivity growth has appeared robust enough that some authors, such as Power (1998), have also inferred policy implications from such findings: "I find little evidence of a robust, economically meaningful correlation between high productivity and high recent investment. This cautions against the efficacy of fiscal policy that is based on the premise that investment causes high productivity" (p. 311). Quite obviously, the absence of a positive relation between investment and productivity represents a big puzzle both to the theory and to the empirics: why investing in tangible assets if there is no apparent benefit? In this paper, we show for France and Italy that an improved methodology that enables to identify large and meaningful investment events allows to recover the expected relation.

Further, also the type of investment is likely to affect the outcome of the process of investment at the firm level. The replacement of obsolete machinery and equipment with newer ones that embed more recent technologies is more likely to induce an increase in productivity than a pure "expansionary" event of investment that does not involve a technological upgrade, as for instance, the setting up of a new plant to increase production capacity. What is probably less intuitive is that even the sheer expansion of the firm by means of replication of already existing activities, might incur in difficulties that are related to the impediments of transfer of knowledge, also within the same organization (Szulanski, 1996). The French database enables us to investigate this issue, as it is possible to observe the increase in the firms' number of plants.

A few other studies before have addressed similar research questions on French or Italian firms. However, either they had to resort to surveys to access actual investment data, thus much limiting the scale of the analysis (Parisi et al., 2006 for Italy) or, in another stream of literature, they had to compute investment as the (adjusted) difference of capital stock over two consecutive years (Bontempi et al., 2004; Del Boca, Galeotti, Himmelberg and Rota, 2008; Del Boca, Galeotti and Rota, 2008 for Italy and Mairesse et al., 1999; Hall et al., 1999; Bond et al., 2003 for France). In this respect, this is the first work to present a large scale study of the patterns of firm level investment and its relation to firm performance for Italy and France. ${ }^{6}$

In this paper, we focus on the heterogeneity in investment patterns across firms as well as within the firms' time series. The former will indicate which characteristics differentiate investing from noninvesting firms, while the latter will help us understand the factors impacting the timing of such decision. We will focus upon those relevant episodes of firm level investment that are not related to the routinary activity of repair and maintenance yearly conducted by manufacturing firms. As a result, a great deal of attention is devoted to contribute to the methodology for identifying these exceptional episodes of investment, often referred to as spikes in this stream of literature. We then investigate which characteristics make it more likely for a company to undertake an investment project, and relatedly, how the episode of investment impacts on firm performance in the following periods.

The rest of the paper is organized as follows. In Section 2 we describe the database for France and Italy. After documenting the lumpy nature of firm-level investment, in Section 3 we consider and compare different measures of investment spikes in order to account for large capital purchases, and we also introduce our own measure. In Section 4, first we analyze the determinants of the probability to observe a spike, and then we study the effects of such events on firm performance. Section 5 concludes.

\footnotetext{
${ }^{5}$ Licandro et al. (2004) find a positive effect on productivity but which is limited to the sub-group of innovative firms only.

${ }^{6}$ Duhautois and Jamet (2001) used observed investment from the French tax dataset (fichier des Bénéfices réels normaux, INSEE), however they do not investigate the relation between investment spikes and firm performance.
} 


\section{$2 \quad$ Data and Descriptive Statistics}

The present paper draws upon two similar firm-level databases, the Enquête Annuelle d'Entreprise (EAE) and Micro.3, respectively for France and Italy. ${ }^{7}$ A unique feature of the two databases is that they report, besides standard accounting information, the value of the acquisition of tangible and intangible assets in each year.

The EAE databank is collected by the statistical department of the French Ministry of Industry (SESSI) and provided by the French Statistical Office (INSEE). The EAE contains longitudinal data on a virtually exhaustive panel of French manufacturing firms located on the national territory with 20 employees or more, over the period 1989-2007.

Micro.3 is based on the census of Italian firms yearly conducted by the Italian Statistical Office (ISTAT) for the period 1989-2006. It contains information on firms above 20 employees.

In both samples firms are classified according to their sector of principal activity. Our study focuses on the manufacturing industry i.e. sector 171 to 361 in the NACE rev 1.1 classification. Both the Micro. 3 and the French database are quite representative of the two economies, and, more in particular, they account for a large share of their respective manufacturing industries: $40 \%$ in terms of employees and around 60\% when considering value added, see Grazzi et al. (2009).

Furthermore, both databases underwent a change in the data collection process over the years. The criteria for inclusion have changed over time as well as the definition of variables. The latter change in particular reflects the necessary assimilation of the European Union's directives and regulations. ${ }^{8}$ More precisely, some variables such as the capital stock were not available for the whole French sample before $1996 .{ }^{9}$ Instead in the Italian database after 1997 the census of the whole population of firms only concerns companies with more than 100 employees, while in the range of employment 20-99, ISTAT directly monitors a "rotating sample" which varies every five years. In order to increase the coverage of firms in that range Micro.3 resorts, from 1998 onward, to data from the financial statement that limited liability firms have to disclose, in accordance with Italian law. ${ }^{10}$ However, standard data from company accounts do not include observed investment, hence this work does not benefit from the increased number of observations that is available from this other source. As a result, and in view of having a more homogeneous cross-country database we drop the first years from respectively Micro.3 and EAE and focus on the period 1996-2006 (2007 for France). Further, given our interest in tracking the performance of firms over time, we consider only firms reporting data for more than three years. ${ }^{11}$

For what concerns the definition of the variables employed in the empirical analysis, the investment rate (Inv. rate) is the ratio of investment (flow variable) over tangible fixed assets (stock variable), in particular we consider investment in year $t$ over the stock of tangible assets at the end of the previous year, $\left(I_{t} / K_{t-1}\right)$. As a proxy for firm level investment we employ the acquisition of tangible fixed assets, as reported by the firm. ${ }^{12}$ Due to small differences in variable definitions, the Italian database reports the value of acquisitions of machineries and equipment only, whether for France it also includes land and property. Note, however, that over the period 1989-1995 the investment variable for the French dataset is broken down into its main components and in those years the share of land and property

\footnotetext{
${ }^{7}$ Both databanks have been made available to the authors under the mandatory condition of censorship of any individual information. Micro.3 database has been developed through a collaboration between the Italian Statistical Office (ISTAT) and members of the Laboratory of Economics and Management of Scuola Superiore Sant'Anna, Pisa. More detailed information on development of the database Micro.3 are in Grazzi et al. (2009).

${ }^{8}$ Over the last thirty years the process of harmonization of accounting standards has brought about relevant changes to the national legislation: 78/660/EEC on the annual accounts of certain types of companies, 83/349/EEC on consolidated accounts, 86/635/EEC on the annual accounts and consolidated accounts of banks and other financial institutions and 91/674/EEC. More recently the Directive 2006/46/EC of the European Parliament has amended the above sources.

${ }^{9}$ This is because before 1996, firms between 20 and 99 employees were surveyed with a simplified questionnaire.

${ }^{10}$ Limited liability companies (società di capitali) have to provide a copy of their financial statement to the Register of Firms at the local Chamber of Commerce.

${ }^{11}$ For the descriptive analyses that concern the variable investment alone, i.e. Figure 2 and 3 , we employ the whole span of the available sample period, 1989-2007 (2006 for Italy).

${ }^{12}$ We also tested whether adding leased capital in the definition of the investment variable affected the results. As it does not, we do not consider leased capital. The decision to exclude leased capital is also motivated by accounting differences between the two countries. Indeed, the variable is reported as the yearly cost of rents in the French database whereas in the Italian one it is the total indebtment in the year of the investment.
} 
Table 1: Size distribution of firms by size class.

\begin{tabular}{|c|c|c|c|c|c|c|c|c|}
\hline \multirow[t]{2}{*}{ Size Class } & \multicolumn{4}{|c|}{ France } & \multicolumn{4}{|c|}{ Italy } \\
\hline & 1999 & 2002 & 2006 & Pooled & 1999 & 2002 & 2006 & Pooled \\
\hline 20-49 employess & $55.42 \%$ & $54.34 \%$ & $52.59 \%$ & $54.40 \%$ & $31.87 \%$ & $28.94 \%$ & $29.27 \%$ & $30.62 \%$ \\
\hline 50-250 employees & $35.95 \%$ & $36.57 \%$ & $37.95 \%$ & $36.51 \%$ & $56.15 \%$ & $57.89 \%$ & $57.82 \%$ & $56.72 \%$ \\
\hline$\geq 250$ employees & $8.62 \%$ & $9.08 \%$ & $9.46 \%$ & $9.08 \%$ & $11.97 \%$ & $13.17 \%$ & $12.96 \%$ & $12.65 \%$ \\
\hline $\begin{array}{l}\text { Number of obs } \\
\text { Number of firms }\end{array}$ & 18,559 & 18,425 & 15,433 & $\begin{array}{r}207,368 \\
23,474\end{array}$ & 9,053 & 9,265 & 8,428 & $\begin{array}{r}93,137 \\
9,808\end{array}$ \\
\hline
\end{tabular}

Table 2: Means and medians (in brackets) for the sample used in the regressions.

\begin{tabular}{|c|c|c|c|c|c|c|}
\hline & \multicolumn{3}{|c|}{ France } & \multicolumn{3}{|c|}{ Italy } \\
\hline & 1999 & 2002 & 2006 & 1999 & 2002 & 2006 \\
\hline Empl & $116.8(46)$ & $125.6(46)$ & $133.7(48)$ & $170.6(75)$ & $171.7(82)$ & $172.9(84)$ \\
\hline Sales & $20602(5030)$ & $24238(5502)$ & $32905(6590)$ & $44406(12741)$ & $43930(14405)$ & 49614 (15638) \\
\hline LabProd & $48.10(39.87)$ & $48.80(40.57)$ & $55.99(44.03)$ & $53.38(46.38)$ & $54.04(47.28)$ & $54.69(47.85)$ \\
\hline RoS & $0.066(0.065)$ & $0.057(0.060)$ & $0.057(0.057)$ & $0.110(0.099)$ & $0.098(0.091)$ & $0.086(0.080)$ \\
\hline Inv rate & $0.160(0.085)$ & $0.136(0.069)$ & $0.117(0.059)$ & $0.159(0.084)$ & $0.158(0.064)$ & $0.137(0.050)$ \\
\hline
\end{tabular}

Note: Sales and Labor Productivity are in thousands of euro and deflated according to the production price index.

over total investment is in between $14 \%$ and $18 \%$. Further, the two investment variables for Italy and France, although bearing such slight differences in the definition, display comparable statistical properties and trend over time as shown in Figure 1 below.

In addition to the value of investment and capital stock, the French dataset also includes information on the number of plants making up the firm. We employ this variable to enrich the empirical analyses as the setting up of a new plant allows to identify episodes of investment that are associated with expansion and capacity building rather than replacement investment.

Other variables employed in the empirical analysis are the number of employees (Empl.), labor productivity (Prod), computed as value added per worker, total sales (Sales) and return on sales (RoS) as a proxy for profitability. RoS is defined as Gross Operative Margin ${ }^{13}$ over total sales. In particular, this definition of profitability has been chosen because it is not heavily influenced by accounting interferences. We also take into consideration the growth rates, as logarithmic differences, of these variables.

Tables 1 and 2 report some descriptive statistics for the sample employed in the econometric analysis. In particular, Table 1 shows that for Italy, the rotating sample in the range of employment 20-99 generates a firm size distribution that weights relatively more bigger firms as compared to France. Relatedly, this is associated with a smaller number of observations for Italy with respect to France. Those differences in the firm size distribution between the two countries also generate bigger averages (and medians) for some of the variables of interest, see Table 2.

The econometric analysis that follows is performed both on the pooled sample of industries as well as by sector. In this respect, we are interested in accounting for how differnt technological regimes across sectors might affect the link between investment and firm performance. To this end, firms are grouped according to the Pavitt taxonomy that accounts for the diverse sources of technology,

\footnotetext{
${ }^{13}$ Gross Operative Margin is valued added minus wages, salaries, and social insurances paid by the firm.
} 
Figure 1: Histograms of investment rates in 1999, 2002 and 2006. France (left) and Italy (right).
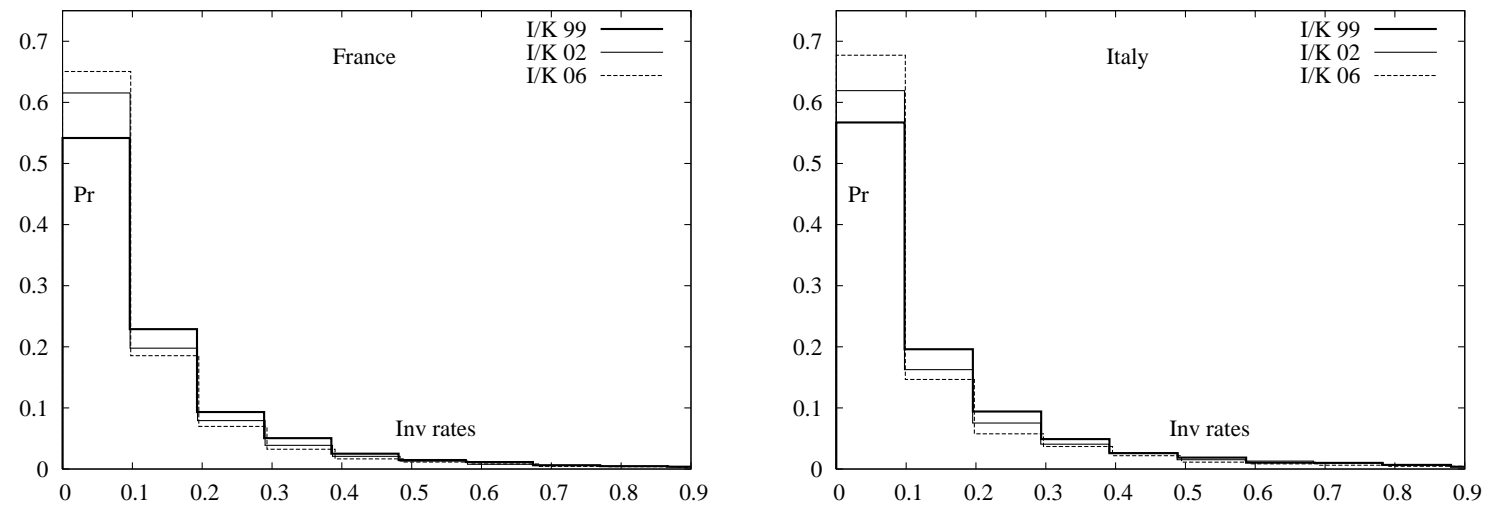

requirements of the users, and intellectual property regimes ${ }^{14}$ (Pavitt, 1984). As the Pavitt taxonomy is a typology based on sectoral innovation processes it appears relevant also for the categorization of firms according to their investment patterns. Indeed, investment opportunities, the scale of production, the technology and capital intensity, the need to buy technology from a supplier versus the possibility of producing it internally are all features much related to the investment decision at the firm level.

\section{$3 \quad$ Investment lumpiness and spike measures}

This section investigates the patterns of firm-level investment in the French and Italian manufacturing industries. We first provide evidence of lumps in investment behavior, then we compare the different methodologies put forward in the literature to identify those spikes and we finally introduce our own contribution to the methodology for identifying "abnormal" events of investment at the firm level.

Figure 1 shows the histograms of investment rates for France (left) and Italy (right) in selected years. Notice that the shape of the distribution does not change over time. From the plot it is apparent that for most firms the investment rate is very low: in 1999, 55\% of firms in France and 57\% in Italy reported an investment rate of $10 \%$ or lower. At the same time, $5 \%$ of French firms (6\% in Italy) display an investment rate of $50 \%$ or more. That of course, points to relevant differences in capital adjustment patterns across firms.

There is, however, at least one more dimension in which the lumpy nature of investment gets revealed and this has to do, within any one firm, with how firms decide to allocate investment over a certain period of time. If we were to observe that, on average, the profile of annual firm-level investment is rather flat, that would support the conjecture of a smooth process of capital adjustment at the firm level. The opposite would be true if we were to observe spikes in such firm level patterns, as they would suggest that firms tend to concentrate investments in few periods. In order to provide evidence on investment lumpiness at the firm level, in Figure 2 we rank for each company the investment carried out in each year from the highest to the lowest and we report the mean and the median investment shares for each rank. ${ }^{15}$ The highest investment share on average accounts for more than $20 \%$ of total

\footnotetext{
${ }^{14} 3$ digit NACE sectors are matched, following the correspondence table in Dosi et al. (2008), with the four Pavitt sectors. Namely, the "supplier-dominated" sector, where technology is acquired through the purchase of new intermediate inputs and which includes the textile, clothing and metal products sectors. The "scale-intensive" sector is characterized by industries for whom economies of scale make it important to acquire a large production capacity, such as for chemicals, agricultural products or motor vehicles. The "specialized suppliers" sector comprises for example the machine-tools and electrical equipment sectors; and the "science-based" includes sectors in which science and research and development play a key role, as for pharmaceuticals, electronics and computer producers.

${ }^{15}$ Notice that in order to compute mean and median over the same number of observations per firms, i.e. 19 years for France and 18 for Italian firms, one has to restrict to a balanced panel. In Figure 2 we are not considering the ratio of two nominal variables (i.e. investment over tangible assets), hence it is needed to deflate investments with the corresponding price index at the 2 digit level of industry disaggregation.
} 
Figure 2: Investment shares by rank in France (left; from 1989 to 2007); and in Italy (right; from 1989 to 2006). Investment shares on the vertical axis; ranks on the horizontal one.
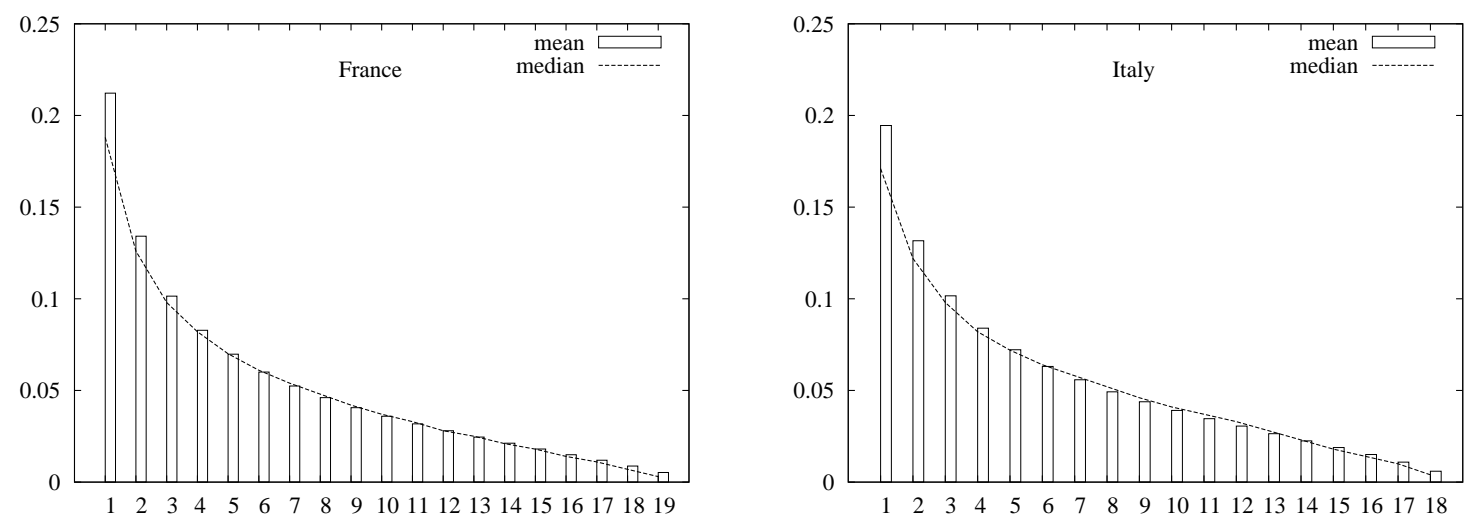

Note: The time period for Italy is 1989-2006, 18 years only.

Figure 3: GDP growth rate and frequency of firm spikes in France and in Italy.
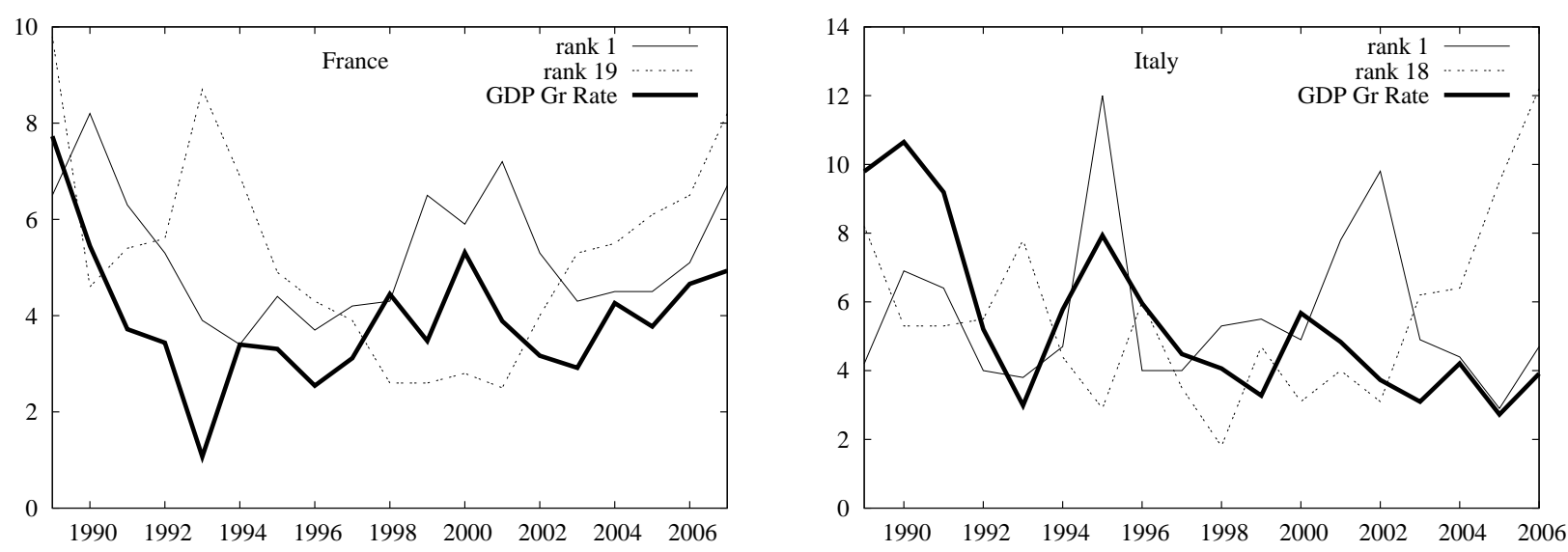

Note: rank 1 is the highest investment episode by firm, rank 19 is the lowest (18 for Italy).

investment. Further, firms concentrate half of the total investment in three years, while investment shares are significantly lower in other years, revealing the lumpy characteristic of the investment variable. Among the possible explanations to account for such lumpiness is the indivisible nature of capital equipment. Notice also that the evidence we report is much similar for both Italy and France, as well as to the findings in Doms and Dunne (1998).

The decision of managers to pursue large investment projects is of course much related to expectations about future business opportunities. As such, a bird-eye view on investment patterns would not be complete without considering the links between this micro-behavior of firms and the business cycle. In Figure 3 we plot the frequency of highest and lowest ranks occurring in every year, and compare them with the evolution of the GDP growth rate in France and in Italy. Figure 3 shows that the growth rate of GDP is positively correlated with the frequency of investment spikes, and negatively correlated with the frequency of lowest values, in both countries. Firms are rather synchronous in their investment decisions and in reacting to aggregate shocks: they invest more frequently during expansion than in periods of contraction. This confirms similar findings in Doyle and Whited (2001) and Gourio and Kashyap (2007). ${ }^{16}$

The descriptive analysis confirms the lumpy nature of investment at both levels of investigation:

\footnotetext{
${ }^{16}$ In the latter article the authors also show that the relative importance of idiosyncratic vs aggregate shocks on firms' investment decisions much depends on the industry under investigation.
} 
within each firm the volume of investment is concentrated in a few episodes accounting for a large share of firm's total investment. And, at the same time, at the industry level, there is a pervasive heterogeneity in the investment rates across firms. Most firms are involved in marginal capital adjustments, which cannot be distinguished from repair and maintenance, whether few firms report high rates of investment, or spikes, that are associated with large investment projects. If one is interested in studying the effects of investment on corporate performance, it is on the latter category of investment episodes that he needs to focus upon.

In the remaining part of the section, we briefly review those measures that have been proposed to identify investment spikes and we finally introduce our own measure that is purported at controlling the relationship between firm size and investment rate.

Power (1998) had already emphasized the difficulties related to identify an appropriate measure that would capture investment spikes: "Since an 'investment spike' is a theoretical rather than a numeric or algebraic concept, and lacks an unambiguous real-world analogue, there is some risk of measurement error, whichever definition of investment spike is employed." (p 303). There exist however some criteria that inform the identification of a spike measure. As put forth in Nilsen et al. (2009) the investment must be large both respect to the history of the firm and to the cross section of the industry. Further, it has to be a rare event, and the definition of the spike must be able to account for a relevant share of total industry investment. Nilsen et al. (2009) also hint at the necessity to account for the relationship that might exist between the investment rate and the capital stock.

We present below four alternative methodologies to identify investment spikes, namely the Absolute rule, the Relative rule, the Linear rule and finally the Kernel rule. The first three are taken from the literature, respectively from Cooper et al. (1999), Power (1998) and Nilsen et al. (2009). The last one is our own contribution to the identification of investment spike, and it allows to overcome some of the shortcomings of the other measures.

The first proxy for investment spike that we consider classifies as lumps investment rates above a threshold that is fixed across firms and industries, hence we label it the absolute rule. To enhance the comparability of results with previous studies we pick $20 \%$ as the threshold value as in Cooper et al. (1999) and other works. This threshold is set with the purpose of eliminating routine maintenance expenditures.

As opposed to the absolute rule, another possibility is to consider spikes as large investment events relative to each firm's investment behavior, as proposed by Power (1998). According to this rule one classifies as a spike all investment events that are larger than a multiple $\alpha$ of the firm's median investment rate over the period of interest, $\tau$ :

$$
I_{i, t} / K_{i, t-1}>\alpha \underset{\tau}{\operatorname{median}}\left(I_{i, \tau} / K_{i, \tau-1}\right)
$$

Power (1998) considers different values of $\alpha$ and finally chooses the value of $1.75,{ }^{17}$ we also pick this value for $\alpha$. This methodology presents the problem that half of the observations classified as spikes according to the relative rule correspond to investment rates below 0.20 . In fact, for firms having a very low median investment rate, spikes would not correspond to a much active investment behavior. Thus, we impose a threshold on the minimum value of the investment rate ${ }^{18}$. As a result, the spike dummy $S_{i, t}$ is identified according to the following rule:

$$
S_{i, t}=\left\{\begin{array}{l}
1 \text { if } I_{t} / K_{i, t-1}>\max \left[\alpha \underset{\tau}{\operatorname{median}}\left(I_{i, \tau} / K_{i, \tau-1}\right), 0.20\right] \\
0 \text { otherwise }
\end{array}\right.
$$

In what follows we will refer to this spike measure as the relative rule.

As already acknowledged by Nilsen et al. (2009), there exists a problem with traditional spike measures which concerns the relation between firm size and investment rate. In order to correct for the excessive volatility of investment of smaller firms, Nilsen et al. (2009) propose a rule that, instead

\footnotetext{
${ }^{17}$ Power (1998) reports that results do not change much with the threshold, as such the author picks the value for which the number of investment episodes to be discarded is the lowest.

${ }^{18}$ Such rule combining the threshold of Power (1998) and Cooper et al. (1999) has also been used by Licandro et al. (2004).
} 
Figure 4: Linear and kernel fit of the relation between size and investment rates for France (left) and Italy (right) in 2003
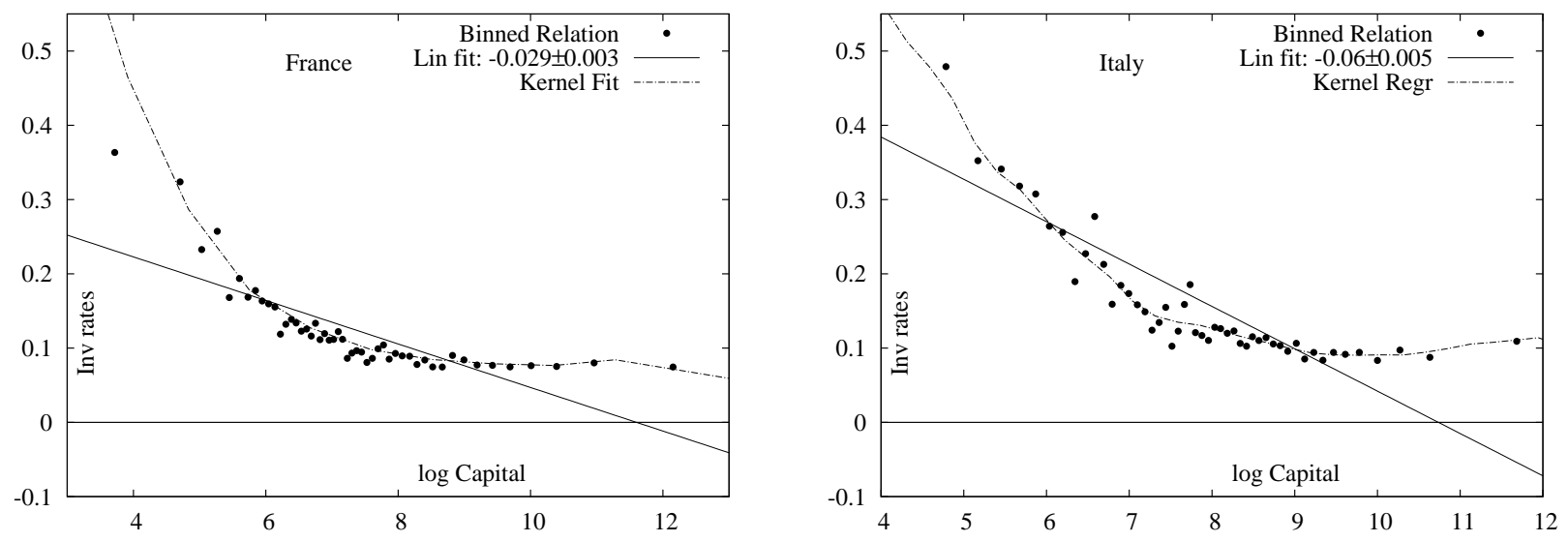

Note: The observations are binned into 50 groups and the mean of each bin is represented on the plot - they are shown as "Binned Relation" on the plot.

of imposing a homogeneous threshold to all firms, conditions the threshold value on the size of the firm. More in particular, Nilsen et al. (2009) show that there exists a negative relation between the firm's capital stock and its investment rate, and characterize such relation with a linear model. ${ }^{19}$ Accordingly, spikes are identified by the following rule:

$$
S_{i, t}=\left\{\begin{array}{l}
1 \text { if } I_{t} / K_{i, t-1}>\max \left[\alpha E\left[\left(I_{i, t} / K_{i, t-1}\right) \mid K_{i, t-1}\right], 0.20\right] \\
0 \text { otherwise }
\end{array}\right.
$$

where $\alpha$ also takes value 1.75. The estimated value can be negative, hence Nilsen et al. (2009) need to define the spike as a maximum between the expected value and a minimum threshold of 0.20. As shown for Italian and French data in Figure 4 the occurrence of negative values arises because the linear fit constantly underestimates investment rates for large values of capital. In what follows we will refer to this spike measure as the linear rule.

Figures 4 and 5 show the dependency of investment rate on firm size for the first and second moments, respectively. Smaller firms, in terms of capital stock, on average tend to display higher investment rates (Figure 4) and also exhibit higher variability (Figure 5) than bigger firms. The negative relation of firm size and investment rates hints at a violation of Gibrat's law when one is considering capital as the proxy for firm size. ${ }^{20}$ A higher variability of investment rates for smaller firms is much coherent with the literature that finds analogous evidence for the relationship between firm size, in terms of sales or number of employees, and growth rates (Stanley et al., 1996).

As it is apparent from Figure 4 there exists a non-linear relationship between the capital stock and investment rates both in the French and Italian databases. In particular, the plot emphasizes that the linear fit provides an accurate description of the relationship only for firms around the median of the firm size distribution. Smaller firms have systematically higher investment rates than predicted by the linear relation, and the same is true for larger firms. In order to account for such non-linearity we employ a non-parametric kernel fit. ${ }^{21}$ The non parametric kernel regression is chosen to avoid imposing an ad hoc structure on the data, also given the absence of a widely accepted theory explaining the relationship between capital and its growth rate.

\footnotetext{
${ }^{19}$ They estimate the following linear relation between observed investment rates and the log of capital: $I_{i, t} / K_{i, t-1}=$ $\gamma_{0}+\gamma_{1} \ln K_{i, t-1}+e_{i, t}$. They then use the estimated value of the investment rate $E\left[\left(I_{i, t} / K_{i, t-1} \mid K_{i, t-1}\right]\right.$ to identify the spikes.

${ }^{20}$ The Gibrat law (refer to Gibrat, 1931 for the original contribution, as well as to Sutton, 1997 for a review) states that firm growth is independent of its size. As such it is also referred to as the "law of proportionate effects". Considering investment rates as growth rates of capital one would therefore expect them to be independent of firm size.

${ }^{21}$ Moments are computed on 15 equispaced points, Epanenchnikov kernel is used (Silverman, 1986).
} 
Figure 5: Log of the standard deviation of investment rates as a function of (log of) capital in 2003.
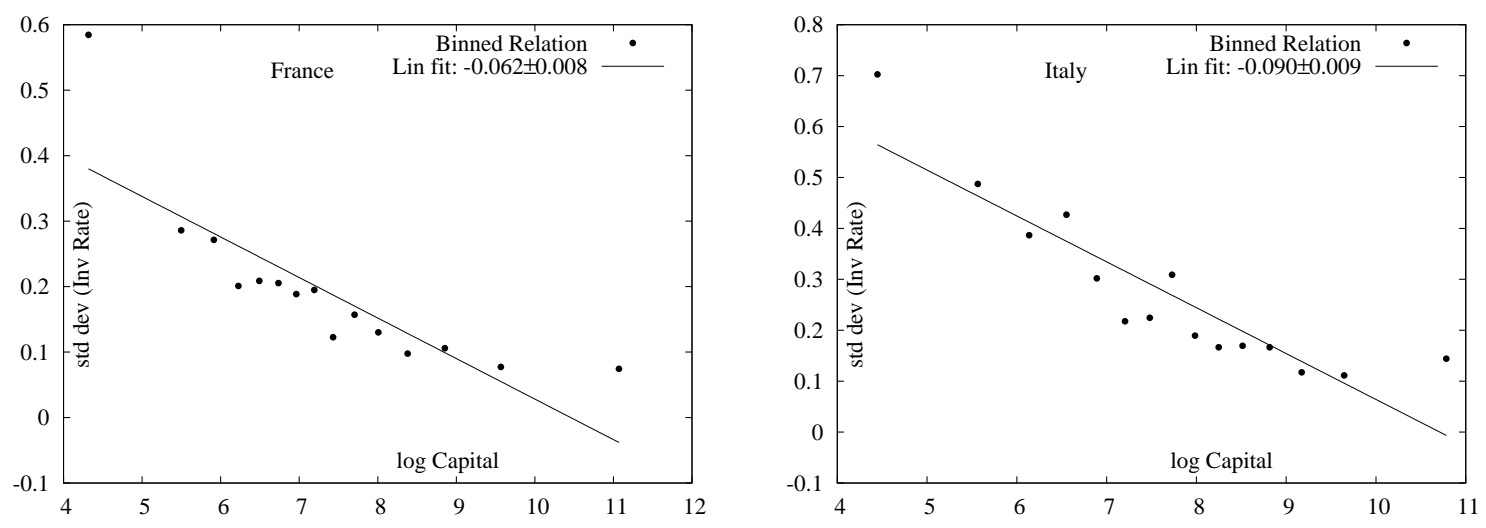

Table 3: Descriptive statistics for different definitions of spikes, 1996-2007

\begin{tabular}{lccccc} 
& $\begin{array}{c}\text { Absolute } \\
\text { rule }\end{array}$ & $\begin{array}{c}\text { Relative } \\
\text { rule }\end{array}$ & $\begin{array}{c}\text { Linear } \\
\text { rule }\end{array}$ & $\begin{array}{c}\text { Kernel } \\
\text { rule }\end{array}$ & $\begin{array}{c}\text { All } \\
\text { Sample }\end{array}$ \\
\hline France & & & & & \\
& & & & & \\
Mean investment rate & 0.47 & 0.54 & 0.60 & 0.53 & 0.14 \\
\% of spikes in nb of obs. & 18.28 & 13.18 & 11.58 & 13.45 & \\
\% of total investment & 28.36 & 20.69 & 27.07 & 34.67 & \\
accounted by spikes & & & & & \\
\hline & & & & & \\
Italy & & & & & \\
& 0.53 & 0.58 & 0.59 & 0.53 & 0.12 \\
Mean investment rate & 15.07 & 11.89 & 12.39 & 13.14 & \\
\% of spikes in nb of obs. & 36.56 & 31.20 & 35.70 & 41.50 & \\
\% of total investment & & & & & \\
accounted by spikes & & & &
\end{tabular}

The kernel spike dummy is identified according to the following rule:

$$
S_{i, t}=\left\{\begin{array}{l}
1 \text { if } I_{t} / K_{i, t-1}>\alpha E\left[\left(I_{i, t} / K_{i, t-1}\right) \mid K_{i, t-1}\right] \\
0 \text { otherwise }
\end{array}\right.
$$

where $\alpha$ is set to 1.75 and the expected value is obtained through kernel estimation within each Pavitt sector. Note that contrary to the relative or linear rules, there is no need set a minimum threshold value to define the kernel spike dummy since the values of the kernel estimation never get negative. In what follows we will refer to this spike measure as the kernel rule.

Table 3 provides a comparison of the performance of the different spike measures. As stated above, any meaningful spike measure should select episodes of investment that are larger than the unconditional investment rates. In this respect, notice that for any of the chosen definitions, the average investment rate conditional on observing a spike exceeds 0.40 which is much larger than the average over the entire sample, which is 0.14 for France and 0.12 for Italy. Another criterion for selection among spike rules concerns their parsimoniousness, that is, their ability to capture a large share of total industry investment with a relative small number of observations. According to this criterion the kernel rule is the best measure. In France (Italy) $13.45 \%$ (13.14\%) of observations are classified as spikes and they account for $34.67 \%$ (41.50\%) percent of total investment.

The main reason for introducing the kernel rule was to appropriately control for the non-linear relation that exists between size and investment rates, as shown by Figure 4. As a final check, Table 4 compares how, and to what extent, the spike measures proposed in the literature and the 
Table 4: Share of observations per size class across different spike measures, 1996-2007.

\begin{tabular}{lccccc} 
Size class & $\begin{array}{c}\text { All } \\
\text { sample }\end{array}$ & $\begin{array}{c}\text { Absolute } \\
\text { rule }\end{array}$ & $\begin{array}{c}\text { Relative } \\
\text { rule }\end{array}$ & $\begin{array}{c}\text { Linear } \\
\text { rule }\end{array}$ & $\begin{array}{c}\text { Kernel } \\
\text { rule }\end{array}$ \\
\hline France & & & & & \\
& & & & & \\
Small & 17.51 & 32.33 & 31.52 & 25.15 & 18.35 \\
Medium & 67.78 & 60.81 & 61.85 & 64.11 & 67.64 \\
Large & 14.71 & 6.86 & 6.63 & 10.73 & 14.01 \\
\hline & & & & & \\
Italy & & & & & \\
& & & & & \\
Small & 8.56 & 13.5 & 13.77 & 11.05 & 6.20 \\
Medium & 65.53 & 69.2 & 68.90 & 68.24 & 65.00 \\
Large & 25.09 & 17.2 & 17.33 & 20.71 & 28.00 \\
\hline
\end{tabular}

Note: "Small" $\ln K<6$, "Medium" $6 \leq \ln K<9$ and "Large" $\ln K \geq 9$.

kernel rule suffer such dependency on size. The table reports how the observations identified as spikes according to the four definitions are distributed among three size classes, and how this compares to the distribution of the whole dataset. It is apparent that both the absolute and relative rules display a size bias: observations classified as a spike according to such rules over-represent small firms, as compared to the whole population, whether larger firms are underrepresented. The linear rule provides a slight improvement on such bias, but it is apparent that the kernel measure is the one that mostly reduces the size bias.

The evidence presented above suggests that spikes identified according to the kernel rule are less biased by size dependency, and yet they possess all desirable characteristics of a spike measure, i.e. they represent a rare and large event of investment for the firm. Further, at the aggregate level, these spikes account for a large share of total investment. As a result, in the empirical analysis that follows, we will focus on spikes as defined by the kernel rule.

\section{Investment and firm performance}

Most of previous works on the topic jointly assessed the relation between firm variables before and after an investment spike, see for instance Sakellaris (2004), Licandro et al. (2004) and Nilsen et al. (2009). In order to reduce potential endogeneity issues related to the joint specification, we run two separate analyses; first we investigate the effects of firm characteristics on the probability to observe a spike, and later we focus on the effects that such spikes produce on firm performance after the investment episode has taken place. The econometric strategy is intended to disentangle those before and after spike elements without imposing ex ante a structure to the relation between investment and firm performance. The objectives are twofold: first, to characterize the features which increase a firm's probability to invest, features which differentiate the group of investing firms from the group of non investing ones; and second to assess the impact of the shock associated with an investment spike on firm performance, in the short as well as the longer term.

Figure 6 presents for France and Italy a simple visualization of the evolution of our target variables around a spike. The plot on the top left of Figure 6 shows, for France and Italy, the evolution of the mean investment rate of single-spiked firms before $(t-2 ; t-1)$, during $(t)$ and after (from $t+1$ to $t+4)$ their investment spike. ${ }^{22}$ The plot confirms that the pattern of investment at the firm level is lumpy: investment rates in the year of the event are five times larger as compared to the adjacent (before and after) years.

The other plots in Figure 6 show the evolution of productivity growth, sales growth and employment growth around an investment spike. Investing firms report (on average) a positive rate of

\footnotetext{
${ }^{22}$ Notice that the plot displays results for firms that reported only one investment spike over the observation period. The econometric analysis that follows is designed to properly account also for multi-spiked firms.
} 
Figure 6: Average firm characteristics around an investment spike. France and Italy, single-spiked firms only.
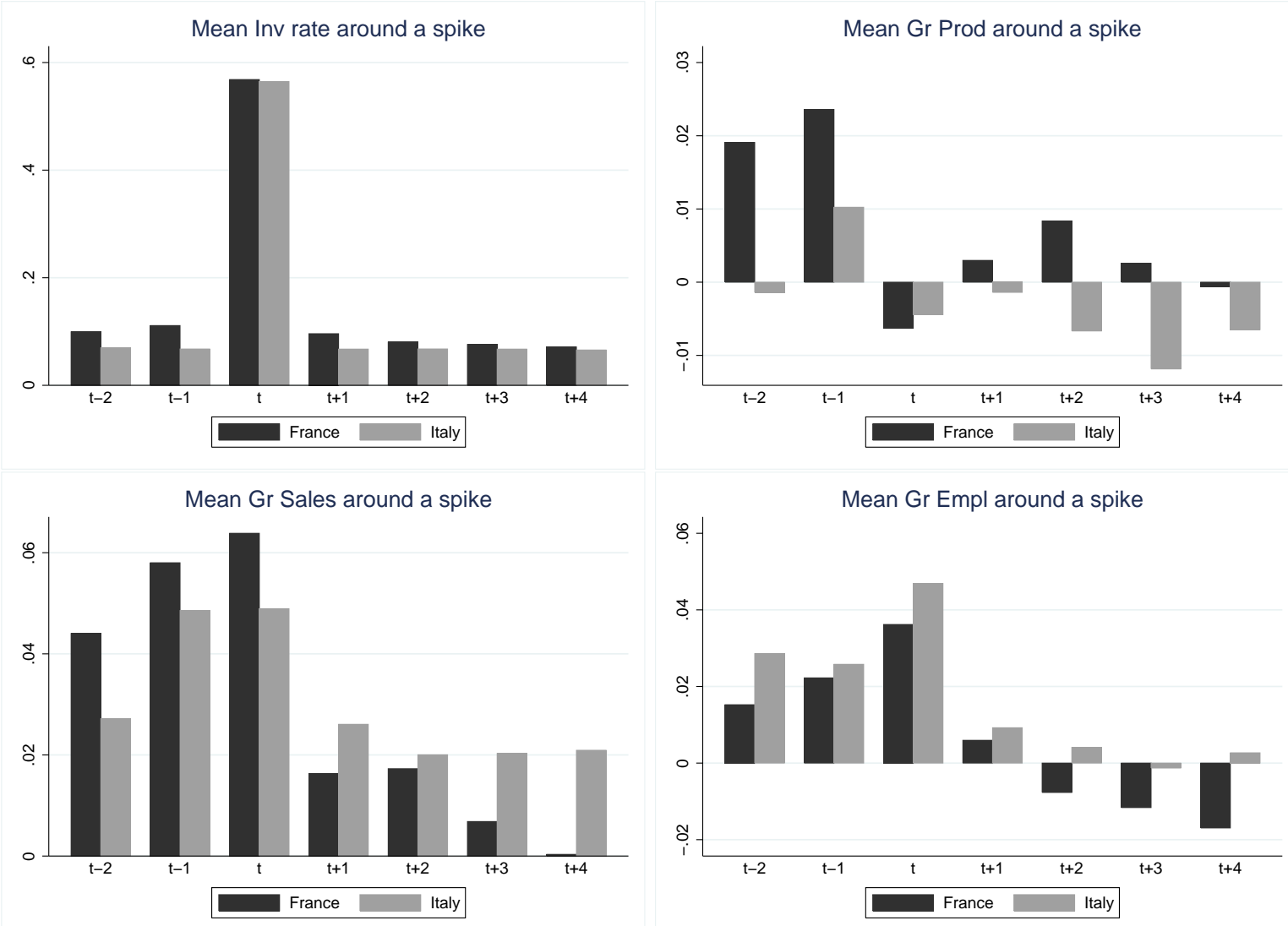

productivity growth in $t-2$ and $t-1$, but undergo a severe shock at time $t$, at which productivity growth is negative. Positive rates are recovered after the investment, but for France only. Growth of sales of investing firms is always positive, it reaches its peaks in year $t-1$ and $t$ and then declines. Employment growth is maximum in year $t$, then declines and eventually gets negative for France.

This first visual investigation suggests an important variability in performance around the investment spike. However it does not allow to contemplate the existence of multi-spiked firms and, more importantly, it does not enable to assess the possible differences existing between the category of investing $v s$ non investing firms. Similarly it cannot control for time or sectoral effects. The econometric analysis presented below intends to address these issues as well as to disentangle the determinants and effects of the relation between investment and firm performance.

\subsection{Determinants of investment spikes}

As put forward by the theory and some earlier empirical works, firm size, financial conditions and growth opportunities are expected to be relevant in explaining firms' investment decisions (Smolny, 2003; Nilsen and Schiantarelli, 2003; Bigsten et al., 2005; Bokpin and Onumah, 2009). Moreover, Sakellaris (2004) finds that employment and investment spikes are synchronized, while Asphjell et al. (2010) specify that employment increases before an investment spike. Another important feature of investment determinants is related to the dynamics of investment across periods. The investigation of the shape of investment spikes hazard functions (defined as the probability of having a new spike as a function of the time since the last spike) provides contrasting evidence (see Cooper et al., 1999; Bigsten et al., 2005; Whited, 2006). The first two works report a negative duration dependence (the likelihood of having a new spike decreases with the time since the last spike), while the latter reveals an increasing hazard function. 
The aim of the present analysis is to enhance the understanding of the conditions under which firms decide to invest. In order to do so, we estimate the effect of firm characteristics on the probability that a firm invests (i.e an investment spike is observed). We thus use a binary dependent variable $S P I K E_{i, t}$ that takes value 1 if there is a spike and 0 if not, and we estimate the following model,

$$
\operatorname{SPIKE}_{i, t}=\beta X_{i, t-1}+\gamma D_{i, t}+v_{i}+u_{i, t}
$$

where $X_{i, t-1}$ is a vector of exogenous variables observed the year before the spike, and $D_{i, t}$ is a vector of duration dummies capturing the time elapsed since last spike. In particular, $D_{1}$ takes value 1 if there is a spike in year $t-1$. $D_{2}$ takes value 1 if there is a spike in $t-2$ but not in $t-1$, and analogously $D_{3}$ takes value 1 if there was a spike in $t-3$ but not in $t-2$ or $t-1$. As such, these dummy variables capture the effect of having had a spike in previous years, on the probability to have a spike in year $t$ (for a similar approach refer to Cooper et al., 1999; Bigsten et al., 2005). $v_{i}$ is a firm-specific unobserved random-effect and $u_{i, t}$ is a serially uncorrelated logistic disturbance term. Time (year) and sectoral (2-digit) dummies are also included in the regressions. The effect of the independent variables on the probability to observe a spike is estimated using a random effects logistic regression..$^{23}$

We run a series of specifications in which the dependent variable is defined with the kernel spike rule. $^{24}$ Table 5 reports results for France and Italy. Firm performance variables include firm size, labor productivity in levels and return on sales (RoS). As proxies for firm size we use the log of the number of employees (Empl.) for both countries and, for France only, the number of plants (Plant). Contrary to some of the previous specifications put forward in the literature (Whited, 1992, 2006), we use profitability computed as the RoS rather than the cash flow ratio as a proxy for access to internal finance. ${ }^{25}$ In a second set of specifications, columns (iii), (iv) and (vi), we consider an additional set of variables that include the growth rate of labor productivity (Prod.Growth), sales (Sales.Growth) and employment (Empl.Growth). We also control for the export status of the firm at time $t-1$ with a dummy. Indeed, as extensively shown in much of the recent trade literature, the status of exporter is a prominent signal of heterogeneity for firms within the same sector (see among others Melitz, 2003; Bernard et al., 2003). Hence being an exporter could also affect the probability of undergoing investment spikes, and, in the absence of firm fixed effects, an export dummy allows to account for such possibility.

We also control for the influence of the macroeconomic environment on firms' investment decision by means of time dummies. As indeed shown in Figure 3 and in several other studies (Federer, 1993; Doms and Dunne, 1998; Chatelain et al., 2003; Gourio and Kashyap, 2007), investment decisions are largely determined by the business cycle due to changes in demand, monetary policy and uncertainty over the cycle.

We first run our set of regressions on the whole sample of observations for France and Italy, controlling for sectoral characteristics using 2-digit sectoral dummies. This represents a much effective way to report results for many sectors condensed in few tables, however this choice also presents the inconvenience of imposing a common structure on the data, as it constrains the coefficients we are mostly interested in not to vary across sectors. In the attempt to reconcile for sectoral variability and preventing the number of tables from growing too much, we chose to aggregate 3 digit industries into Pavitt sectors (refer to Pavitt 1984 for the original contribution and to Dosi et al. 2008 for a correspondence table between Pavitt sectors and 3 digit NACE industries). Therefore we run the

\footnotetext{
${ }^{23}$ The fixed effect estimator is not much appropriate in our analysis given how dummies $D_{i, t}$ are constructed. These dummies capture the time since the last investment spike also controlling for other conditions that depend on the timing of the spike. In particular the firm-level average would differ for firms with the same number of spikes, but with a different distribution of those spikes over the years. As such the within transformation of these firm level dummies would be misleading. The Generalized Method of Moments, which identifies the parameters by minimizing the weighted average of deviations from a group of moment conditions, is therefore also discarded.

${ }^{24}$ As a robustness check, we also run the regressions using the investment rate as a dependent variable, which allows to test whether our spike definition indeed allows to clear out routinary investment events as well as the size bias as described in section 3. Results are not shown here but they confirm such proposition.

${ }^{25}$ This is due to comparability issue, indeed both the French and Italian databases provide with the same set of variables to compute RoS, while the cash flow measure is computed differently in the two countries. However, in both samples, the cash flow and RoS variables are much correlated as suggested by a Spearman's rho coefficient around 0.9 .
} 
Table 5: Determinants of firm level investment for France and Italy

\begin{tabular}{|c|c|c|c|c|c|c|}
\hline & \multicolumn{4}{|c|}{ France } & \multicolumn{2}{|c|}{ Italy } \\
\hline & (i) & (ii) & (iii) & (iv) & $(\mathrm{v})$ & (vi) \\
\hline Empl & $\begin{array}{c}0.014^{* * *} \\
(0.001)\end{array}$ & & $\begin{array}{c}0.011 * * * \\
(0.001)\end{array}$ & & $\begin{array}{c}0.019 * * * \\
(0.003)\end{array}$ & $\begin{array}{c}0.017^{* * *} \\
(0.003)\end{array}$ \\
\hline Plant & & $\begin{array}{c}0.011^{* * * *} \\
(0.002)\end{array}$ & & $\begin{array}{c}0.009^{* * *} \\
(0.002)\end{array}$ & & \\
\hline RoS & $\begin{array}{c}0.225^{* * *} \\
(0.013)\end{array}$ & $\begin{array}{c}0.232^{* * * *} \\
(0.013)\end{array}$ & $\begin{array}{c}0.187 * * * \\
(0.013)\end{array}$ & $\begin{array}{c}0.192^{* * *} \\
(0.013)\end{array}$ & $\begin{array}{c}0.126^{* * *} \\
(0.041)\end{array}$ & $\begin{array}{c}0.150^{* * *} \\
(0.042)\end{array}$ \\
\hline Prod & $\begin{array}{c}0.007^{* * *} \\
(0.003)\end{array}$ & $\begin{array}{l}0.005^{*} \\
(0.003)\end{array}$ & $\begin{array}{c}0.010^{* * *} \\
(0.002)\end{array}$ & $\begin{array}{c}0.009^{* * *} * \\
(0.003)\end{array}$ & $\begin{array}{c}0.028^{* * *} \\
(0.008)\end{array}$ & $\begin{array}{c}0.024^{* * *} \\
(0.009)\end{array}$ \\
\hline Export & $\begin{array}{c}0.002 \\
(0.002)\end{array}$ & $\begin{array}{c}0.007^{* *} \\
(0.002)\end{array}$ & $\begin{array}{c}0.002 \\
(0.002)\end{array}$ & $\begin{array}{c}0.004^{* *} \\
(0.002)\end{array}$ & $\begin{array}{r}-0.002 \\
(0.009)\end{array}$ & $\begin{array}{c}0.006 \\
(0.010)\end{array}$ \\
\hline D1 & $\begin{array}{c}0.127^{* * *} \\
(0.003)\end{array}$ & $\begin{array}{c}0.126^{* * *} \\
(0.003)\end{array}$ & $\begin{array}{c}0.118^{* * *} \\
(0.003)\end{array}$ & $\begin{array}{c}0.117^{* * *} * \\
(0.002)\end{array}$ & $\begin{array}{c}0.127^{* * *} \\
(0.008)\end{array}$ & $\begin{array}{c}0.121^{* * *} \\
(0.008)\end{array}$ \\
\hline D2 & $\begin{array}{c}0.060^{* * *} \\
(0.003)\end{array}$ & $\begin{array}{c}0.059^{* * *} \\
(0.003)\end{array}$ & $\begin{array}{c}0.058^{* * *} \\
(0.003)\end{array}$ & $\begin{array}{c}0.058^{* * *} \\
(0.003)\end{array}$ & $\begin{array}{c}0.076^{* * *} \\
(0.008)\end{array}$ & $\begin{array}{c}0.072^{* * *} \\
(0.008)\end{array}$ \\
\hline D3 & $\begin{array}{c}0.046^{* * *} \\
(0.003)\end{array}$ & $\begin{array}{c}0.046^{* * *} \\
(0.002)\end{array}$ & $\begin{array}{c}0.045^{* * *} \\
(0.003)\end{array}$ & $\begin{array}{c}0.045^{* * * *} \\
(0.003)\end{array}$ & $\begin{array}{c}0.056^{* * *} \\
(0.010)\end{array}$ & $\begin{array}{c}0.053^{* * *} \\
(0.010)\end{array}$ \\
\hline Prod. Gr & & & $\begin{array}{c}0.004 \\
(0.004)\end{array}$ & $\begin{array}{c}0.003 \\
(0.004)\end{array}$ & & $\begin{array}{r}-0.010 \\
(0.012)\end{array}$ \\
\hline Sales Gr & & & $\begin{array}{c}0.040 * * * \\
(0.005)\end{array}$ & $\begin{array}{c}0.040^{* * *} \\
(0.005)\end{array}$ & & $\begin{array}{c}0.052^{* *} \\
(0.016)\end{array}$ \\
\hline Empl. Growth & & & $\begin{array}{c}0.074^{* * *} \\
(0.007)\end{array}$ & $\begin{array}{c}0.077^{* * * *} \\
(0.007)\end{array}$ & & $\begin{array}{l}-0.001 \\
(0.021)\end{array}$ \\
\hline Year dummies & Yes & Yes & Yes & Yes & Yes & Yes \\
\hline Sector dummies & Yes & Yes & Yes & Yes & Yes & Yes \\
\hline Observations & 133794 & 133745 & 129107 & 129066 & 19809 & 18896 \\
\hline Brier score & 0.1083 & 0.1087 & 0.1040 & 0.1042 & 0.1364 & 0.1336 \\
\hline
\end{tabular}

Notes: Table reports random effects logistic regression of noted firm characteristics on the probability to observe an investment spike. Marginal effects at means are reported, standard errors in parentheses. Asterisks denote significance levels (***: p <1\%; **: $\mathrm{p}<\% 5 \%$; $: \mathrm{p}<10 \%$ ).

same specifications on the four macro industrial sectors according to the Pavitt taxonomy. Finally, we evaluate the accuracy of the different specifications by means of the Brier Score (Brier, 1950) which measures the average squared deviation between the predicted probabilities to observe a spike given the estimated coefficients and the actual data. ${ }^{26}$ Thus a lower score provides evidence of a better performance of the model.

Results are reported in Table 5. Further, Figure 7 displays the marginal effects for profitability and productivity, computed at the deciles of the respective distributions, on the probability to observe an investment spike. Columns (i) and (v) of Table 5 employ the number of employees as proxy for firm size and suggest that in both countries higher employment in $t-1$ has a positive effect on the probability of having a spike in year $t$. This represents a residual effect of size given that our spike measure already accounts for differences in terms of firms' capital stock. As captured by RoS, a higher profit rate in year $t-1$ increases the probability of having a spike the following year. In this work we do not rely on a direct measure of financial constraints, however profitability, which is our measure for the capacity of the firm to self-finance, turns out to be relevant in increasing the probability of carrying out investment projects. The probability of a (French or Italian) firm to invest is sensitive to changes in the ability to self-finance, suggesting that internal and external sources of finance are not perfectly

\footnotetext{
${ }^{26}$ More precisely, for each firm $i$, the score is given by $\frac{1}{N} \sum_{i=1}^{N}\left(Y_{i}-P_{i}\right)^{2}$, where $N$ is the number of firms, $Y_{i}$ is the observed event $\left(Y_{i}=1\right.$ if there is a spike and $Y_{i}=0$ if not), and $P_{i}$ is the probability that firm $i$ experiences a spike given the estimated coefficients of the dynamic logit regression.
} 
Figure 7: Marginal effects for Profitability and Productivity (computed at distributions deciles) on the probability of having an investment spike. Error bars represent one standard error.
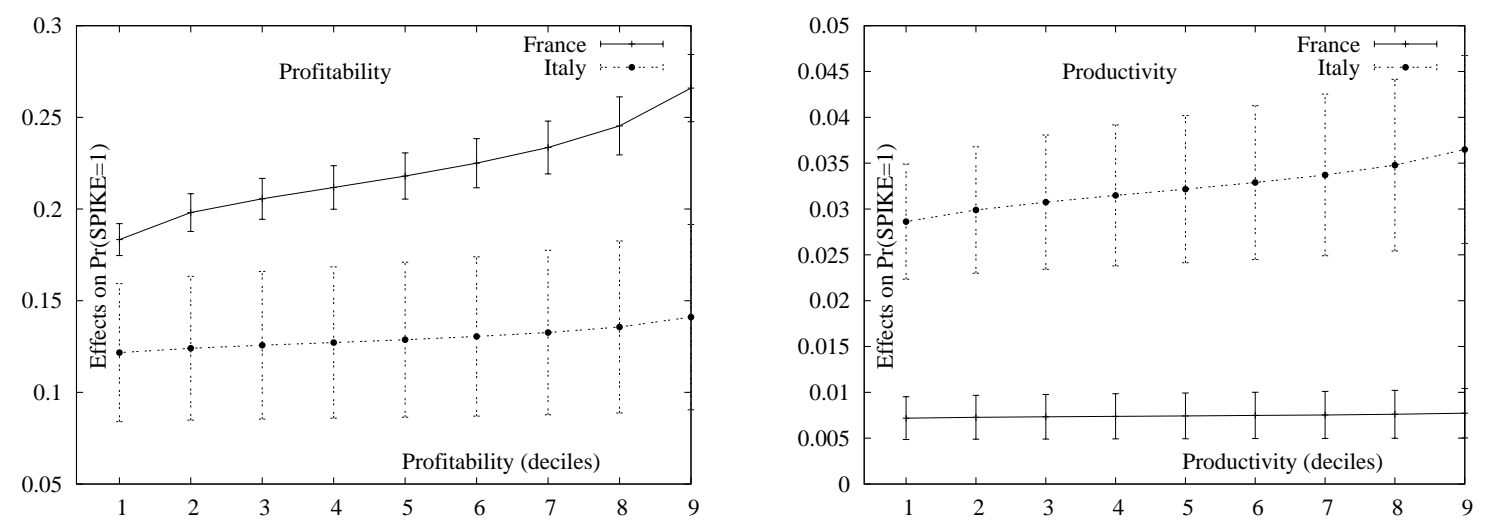

substitutable, which in turn is evidence of the existence of financial constraints to investment. Such result is consistent with previous findings on the subject (Schiantarelli, 1996; Audretsch and Elston, 2002; Whited, 2006). ${ }^{27}$ The graph on the left of Figure 7 plots, for Italy and France, the effects on the probability to observe a spike for an hypothetical firm at the means of independent variables and whose profitability varies, taking values at each distribution decile. It appears that the marginal effect of profitability on the probability to have a spike is increasing in the value of the variable for France (plain line) but not for Italy (dashed line).

Columns (i) and (v) of Table 5 also reveal that higher labor productivity is related to a higher probability of observing a firm level spike. Analogously, the graph on the right of Figure 7 plots, for Italy and France, the effects on the probability to observe a spike for an hypothetical firm at the means of independent variables and whose productivity takes values at the distribution deciles. As far as productivity is concerned, there is not much evidence of different responses when computing the effects at each decile.

Quite surprisingly, the coefficient accounting for the export status does not turn out to be relevant in explaining the investment decision. To date, the only evidence on this relation reports an increase in investment for firms preparing to export (López, 2009) however nothing was said about different patterns of investment for firms already having the status of exporters.

Regression results also suggest that having had an investment spike in the previous years increases the probability of having a spike in year $t$. These patterns, which hold both for France and Italy, suggest that large investment projects are likely to span over more than one fiscal year. Such "multiyear spikes" are quite frequent in the data, representing nearly $44 \%$ and $33 \%$ of spikes in the French and Italian datasets, respectively. As a robustness check we have also run the same regressions without the multi-year spike observations. Results, which are not shown here, do not change in a relevant manner. Also notice that in both countries the effect of past spikes is always positive and significant, however its magnitude decreases over time: having had a spike three years ago is around one third as important in explaining today's spike as compared to having had a spike in the past year.

Overall, regression results are much coherent for France and Italy, conferring a wider breadth to our findings.

As mentioned earlier, for the French database the number of plants per firms is also available, and we use it as an alternative proxy for the size of the firm in columns (iii) and (iv) of Table $5 .{ }^{28}$ This second model specification shows that results are robust to the inclusion of this alternative size proxy. The only noticeable difference concerns the effect of firms' export status that becomes positive and

\footnotetext{
${ }^{27}$ The interpretation of a positive relation between past profitability and investment as proof for the presence of financial constraints is further confirmed by a test on the interaction effect between profitability and firm size, on the probability to invest. Results, not shown here, reveal that the sensitivity of investment to profitability is even greater for the category of small firms, defined as those firms with a number of employee below the median.

${ }^{28}$ Notice that the variable "plant" reports a few more missing observations than the other variables.
} 
significant when considering the number of plants as a proxy for firm size. Notice however that the specification employing the number of employees as the proxy for size performs relatively better in terms of Brier Scores.

Columns (iii) (iv) and (vi) of Table 5 also include the first differences of sales, employment and productivity. As expected, the inclusion of more explanatory variables improves the accuracy of the model in predicting the investment spike, as suggested by a lower Brier Score. The magnitude of the coefficients of variables in levels is almost unchanged, whether some interesting patterns emerge in the role of growth rates. A growth of sales in the previous year has a positive effect on the probability of realizing a large investment in year $t$, both in France and Italy. This is coherent, for instance, with the need of the firm to expand its capacity as sales are growing. Moreover a positive effect of past sales growth lends support to the conjecture that internal finance is much relevant for the decision of investing at the firm level.

The trend in productivity growth, on the contrary, does not appear to influence that decision: an increase in productivity the previous year is not likely to affect the investment decision this year. Results on growth of employment, although only significant for France, are much interesting for the perspective they provide in terms of timing of the decision of hiring and investing: an increase in employment anticipates capital adjustment episodes. This finding is coherent with the results in Sakellaris (2004) and Asphjell et al. (2010).

In the Appendix, Tables 11 and 12 report the results of all the specifications of Table 5 on four macro industrial sectors, identified according to the Pavitt taxonomy (Pavitt, 1984). Results of the analyses at the sectoral level are much coherent with those on the entire sample. As shown in Table 11, when significant, size, return on sales, productivity and past spikes all have a positive effect on the occurrence of investment spikes as found on the entire sample, Table 5 columns (i), (ii) and (iv). Still, we find a certain heterogeneity in the strength of these impacts across sectors. For example return on sales (RoS) has a weaker impact in the French science-based sector and is not significant at all in the Italian supplier-dominated and science-based sectors. This points to differences in the reliance on self-financing across sectors. Table 12 confirms the results at the aggregate level also when including variables in first differences, with a few exceptions. Still, if productivity growth had no significant impact in the French database as a whole, a negative relation emerges for the science-based sector, Table 12. Besides, in this particular French sector, the probability to invest is strongly associated with a past increase in sales (with a coefficient that is much higher than for other sectors), but not with an increase in the number of employees. Finally, although the export dummy turns out not to be significant in explaining investment spikes, the sectoral analysis uncovers some differences in the French dataset as the export dummy is significant and positive in the scale-intensive sector, but significant and negative in the supplier-dominated sector.

To sum up, the analysis of the determinants of investment spike suggests a high degree of similarity for the two countries. Fast growing, profitable and productive firms display a higher probability to invest, while past productivity growth has almost no impact. Further, the export status is not systematically associated with a higher probability to invest. Finally, the hazard function is decreasing over time.

\subsection{Effects of investment spikes on firm performance}

The second broad research question that we address in this work regards the effects of investment spikes on firm performance. Several reasons might lead firms to invest in tangible assets, such as satisfying an increasing demand, as revealed by the above analysis. Besides the capacity expansion motive, a firm might also invest in order to buffer technological obsolescence by replacing existing machinery and equipment, or prepare the launch of new series of products, which requires new machinery. Therefore it is expected that investment spikes should be positively correlated with firm size, firm growth as well as firm efficiency.

A number of papers have investigated the link between investment and productivity, as well as its growth rate. Starting with the seminal work of Power (1998) that could resort on a rich set of US plant level data, many scholars have begun to investigate the relation between investment and firm performance. Among these works, we refer to Bessen (1999), Huggett and Ospina (2001), Sakellaris 
(2004), Licandro et al. (2004), Nilsen et al. (2009) and Shima (2010). More in particular, Power (1998) finds almost no evidence of a positive correlation between productivity and high levels of recent investment, whether Huggett and Ospina (2001) report a fall in productivity after an investment spike. Still, Bessen (1999) finds that in new plants, labor productivity increases with time, which he attributes to a learning-by-doing process. Power also finds a positive correlation between labor productivity and plant age, and concludes that "selection and learning could be important determinants of the pattern of productivity across plants" (Power, 1998, p. 311). However, and more relevant for the present work, she doesn't find such relation with investment age. Finally, Shima (2010) also reports a negative relation between technical efficiency and machinery age.

Using a different econometric approach, Nilsen et al. (2009) find evidence of a positive and significant effect of contemporaneous (same year) investment on labor productivity, but such positive effect vanishes in the following years. However their analysis also reveals that the group of firms having at least one investment spike over the sample period shows a significantly higher level of productivity than the group with no investment spike. Licandro et al. (2004) matching information on the type of investment and on the innovation process at the firm level try to identify groups of firms that gather investments episodes with similar firm-level characteristics. The underlying hypothesis is that different types of investment are related to different effects on the variables of interests. To this purpose they classify a firm as expansionary when it declares to have increased the number of plants in the sample period; replacement investment is instead proxied by the identification of an innovative firm, which declares process innovations more frequently. Applying this distinction, Licandro et al. (2004) are able to find that expansionary firms reveal a relatively strong increase in their productivity level in the year of the spike, while the impact on innovative firms' productivity is observed after a delay of four years. They explain that the former are able to integrate the productivity gains from the investment instantaneously, while the latter exhibit longer learning curves. In this work, we will also consider the increase in the number of plants as evidence of expansionary investment. Notice however that we define expansionary episodes while Licandro et al. (2004) identified expansionary firms. As previously mentioned, the number of plants is available only in the French dataset.

A thorough assessment of the link between productivity growth and investment spikes, requires to study the dynamics of the interrelation between the adjustment episodes and other firm level variables over time. In order to properly account for such dynamics, it is possible to rely on a methodology proposed by Sakellaris (2004) using US data and employed (with some modifications) also by Nilsen et al. (2009) on Norwegian data and Asphjell et al. (2010) on Dutch data.

Building on such approach, we investigate the impact of investment spikes on seven performance variables. They include total sales ${ }^{29}$ (Sales), the number of employees (Empl) and labor productivity (Prod). We also consider the growth rates of the variables above and finally we also study the effect of the investment spike and its timing on return on sales (RoS). We regress each performance variable on a group of spike dummy variables. For each of the seven regressions, taking $X_{i, t}$ as one of our variables of interest, we estimate the following model:

$$
X_{i, t}=\beta D_{i, t}+\gamma_{1} \text { DBefore }_{i, t}+\gamma_{2} \text { DLeast }_{i}+v_{i}+\epsilon_{i, t}
$$

where $D_{i, t}$ is a vector of duration dummies which is composed of three elements $D_{t 0}, D_{t 1}$ and $D_{t 2}$. Analogously to the previous investigation on the determinants of investments, $D_{t 0}$ takes value 1 if the investment spike is contemporaneous, occurring in year $t ; D_{t 1}$ takes value 1 if the investment took place at $t-1$, but not in $t$ and finally $D_{t 2}$ takes value 1 if the spike occurred at $t-2$, but not in $t-1$

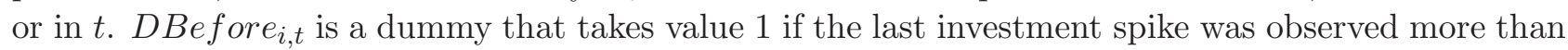
two years before $t$ and zero otherwise. Thus the coefficient $\gamma_{1}$ accounts for the effect of investment spikes on firm performance in the long run. The dummy DLeast $t_{i}$ takes value 1 if firm $i$ had at least one investment spike over the sample period and zero otherwise, hence it represents a sort of fixed effects for the group of firms reporting at least one investment spike. Finally, $v_{i}$ is a firm-specific unobserved random-effect and $\epsilon_{i, t}$ is the error term. Time (year) and sectoral (2-digit) dummies are also included. The same argument as before applies for choosing a random over a fixed effects model, refer also to footnote 23. In addition, it is now possible to appreciate the effects on performance of

\footnotetext{
${ }^{29}$ As before, all variables in levels are taken in logs.
} 
belonging to the group of "investing firms", those with DLeast $=1$, versus the group of firms never reporting an investment spike.

We also consider a further specification of the model that enables to identify the effects of strictly expansionary events from non-expansionary ones. Using the number of plants, available in the French database, we construct a dummy, DPlant ${ }_{i, t}$, which takes value 1 if the firm has increased its number of plants between $t-1$ and $t .^{30}$ Those capture expansionary episodes, and as such they allow to study the effect of setting up a new plant on firm performance. We thus estimate the following model ${ }^{31}$

$$
X_{i, t}=\beta D_{i, t}+\lambda \text { DPlant }_{i, t}+\gamma_{1} \text { DBefore }_{i, t}+\gamma_{2} \text { DLeast }_{i}+v_{i}+\epsilon_{i, t}
$$

Results are presented in Tables 6 to 9 . For each table we report regression results for both specifications presented above: the first set of results refers to the estimation of equation 2 and shows the effect of past investment spikes on firm performance in France (column i) and in Italy (column iii); the second set of results (equation 3) additionally investigates the effect of reporting an increase in the number of plants on French firms' performance (column ii). The comparative approach is also aimed at testing the robustness of the results to changes in the institutional context.

If we have previously shown that investment is determined both in Italy and in France by similar firm characteristics, the analysis of the effects of investment spikes on firm performance reveals significant differences across countries. In general we observe a stronger effect of investment episodes on French firms than on Italian ones. Moreover, complementing the analysis with the impact of the increase in the number of plants per firms discloses further insights on the role played by "pure" expansionary investment. In the following we present results for the whole French and Italian samples, controlling for sectoral effects by means of dummies. In addition, we also perform the same analysis at the Pavitt sectoral level and comment on the additional results to provide a more disaggregated perspective. ${ }^{32}$ Finally, as a robustness check, we perform our analysis removing the multi-year spike events, that is, spikes occurring in adjacent years, as they might bias the analysis of the dynamic effect of investment on performance. Results, not shown here, do not change in a relevant manner except for a small decrease in coefficients $D_{t 0}, D_{t 1}, D_{t 2}$ and a small increase in the DLeast coefficient.

\section{Profitability}

As shown earlier firms tend to invest when their financial conditions, as proxied by the profitability rate, are relatively good. The positive and significant coefficient of the variable DLeast in columns (i) and (ii) of Table 6 captures the effect of belonging to the category of investing firms. It tells us that firms having had at least an investment episode over the sample period are relatively more profitable than non-investing firms in the French sample; yet it is not possible to detect a significant difference between the two groups of firms in Italy.

When considering the timing of those effects on profitability, and after controlling for the fixed effect of being an investor, as proxied by DLeast, columns (i) and (iii) of Table 6 , we find evidence for France of a contemporaneous increase in profitability, $D_{t 0}$, but not for Italy. Indeed, we find no significant relation between past investment and profitability for Italian firms. The contemporaneous increase in profitability, $D t 0$, is 0.01 in France, and it is significant up to period $t-1$. Then the effect of investment on profitability is again positive and significant when considering spikes occurred more than two years before, DBefore.

In addition, if one also considers the differences between the group of firms reporting and not reporting spikes $\left(D_{t 0}+\right.$ DLeast $)$ in the year of the investment the recorded increase in profitability

\footnotetext{
${ }^{30}$ Analogously to equation 2 DPlant $_{t 0}$ takes value 1 if the increase in number of plants is contemporaneous; DPlant $t_{t}$ takes value 1 if it occurred in $t-1$, but not in $t$ and finally DPlant $t_{t 2}$ takes value 1 if the increase in the number of plants was at $t-2$, but not in $t-1$ or in $t$.

${ }^{31}$ Notice that the opening of a new plant does not always overlap with an investment spike, as defined by the kernel, because the starting of a new plant is not always associated with a high investment rate. The average investment rate, conditional on opening a new plant in the same year, is around $20 \%$; the unconditional average is $14 \%$, see Table 3 . The inclusion of an interacted dummy to capture the joint occurrence of investment spike and new plant does not provides additional information as the coefficients are seldomly significant. Hence results for the interacted dummy have not been included, but are available upon request.

${ }^{32}$ Tables of results at the Pavitt sectoral level are shown in the Appendix in Tables 13 to 19.
} 
Table 6: Effect of Investment on Profitability

\begin{tabular}{|c|c|c|c|}
\hline & \multicolumn{2}{|c|}{ France } & \multirow{2}{*}{$\begin{array}{c}\text { Italy } \\
\text { RoS } \\
\text { (iii) }\end{array}$} \\
\hline & $\begin{array}{l}\text { RoS } \\
\text { (i) }\end{array}$ & $\begin{array}{l}\text { RoS } \\
\text { (ii) }\end{array}$ & \\
\hline Dt0 & $\begin{array}{c}0.010^{* * *} \\
(0.002)\end{array}$ & $\begin{array}{c}0.009 * * * \\
(0.001)\end{array}$ & $\begin{array}{c}0.009 \\
(0.027)\end{array}$ \\
\hline Dt1 & $\begin{array}{c}0.007 * * * \\
(0.002)\end{array}$ & $\begin{array}{c}0.007^{* * *} \\
(0.001)\end{array}$ & $\begin{array}{c}0.008 \\
(0.029)\end{array}$ \\
\hline Dt2 & $\begin{array}{l}-0.001 \\
(0.003)\end{array}$ & $\begin{array}{c}0.005^{* * *} \\
(0.001)\end{array}$ & $\begin{array}{c}0.003 \\
(0.031)\end{array}$ \\
\hline DBefore & $\begin{array}{c}0.007 * * * \\
(0.002)\end{array}$ & $\begin{array}{c}0.004^{* * *} \\
(0.001)\end{array}$ & $\begin{array}{c}0.008 \\
(0.025)\end{array}$ \\
\hline DLeast & $\begin{array}{c}0.013^{* * *} \\
(0.005)\end{array}$ & $\begin{array}{c}0.016^{* * *} \\
(0.003)\end{array}$ & $\begin{array}{c}0.041 \\
(0.032)\end{array}$ \\
\hline DPlant t0 & & $\begin{array}{c}-0.008^{* * * *} \\
(0.002)\end{array}$ & \\
\hline DPlant t1 & & $\begin{array}{c}-0.008^{* * *} \\
(0.002)\end{array}$ & \\
\hline DPlant t2 & & $\begin{array}{l}-0.012 \\
(0.002)\end{array}$ & \\
\hline Year dummies & Yes & Yes & Yes \\
\hline Sector Dummies & Yes & Yes & Yes \\
\hline Observations & 148009 & 123559 & 24540 \\
\hline R-squared & 0.004 & 0.012 & 0.001 \\
\hline
\end{tabular}

Notes: Table reports results of regression (random effects) for the impact of investment timing on firm performance, standard errors in parentheses. Asterisks denote significance levels (***: p <1\%; **: p <\% 5\%; * p $<10 \%)$.

becomes substantially larger. Next, coefficients DPlant $_{t 0}$, DPlant $_{t 1}$ and DPlant $t_{2}$ in column (ii) of Table 6 allow to identify the effects of the setting up of a new plant for French firms. Quite interestingly the effect on profitability of starting a new plant is negative and significant, both for the same and one year lag.

This first set of results already emphasizes a relevant difference between the two countries as it underlies a great deal of the difficulties encountered by the Italian manufacturing system over the last fifteen years or so: large investment projects had no appreciable returns to shareholders in the period 1997-2006 (for a complementary analysis refer to Dosi et al., 2012). Results for France show instead a positive effect of investments on return on sales, although the setting-up of a new plant represents a negative shock.

\section{Productivity and productivity growth}

Results in Table 7 show that having reported at least one spike over the observation period, DLeast, is associated with higher productivity both in France and Italy, columns (i), (ii) and (v). Further, there is a positive contemporaneous effect of investment spike on productivity for both countries, $D_{t 0}$. Such positive effect persists also one year after the spike in both countries, $D_{t 1}$, and also at longer lags, $D B e f o r e$. If we add the effect of being an investor (DLeast), then in the year of the spike an investing firm is on average $0.093 \mathrm{log}$ points (10 percent) more productive in France, whether the difference is smaller for Italy, $0.054 \mathrm{log}$ points $(5.5$ percent). The impact of investment on productivity is quite stable in the years after the spike in the French case whether it slightly decreases for Italian firms.

When accounting for the occurrence of expansionary episodes as proxied by the setting up of a new plant, column (ii), the lasting positive effect of investment spikes on productivity is confirmed. However, quite interestingly, it emerges that starting a new plant is not associated with higher productivity, as DPlant ${ }_{t 0}$ is not positive. Overall, results from column (ii) support the conjecture that 
Table 7: Effect of Investment on Productivity and its growth rate

\begin{tabular}{|c|c|c|c|c|c|c|}
\hline & \multicolumn{4}{|c|}{ France } & \multicolumn{2}{|c|}{ Italy } \\
\hline & $\begin{array}{l}\text { Prod } \\
\text { (i) }\end{array}$ & $\begin{array}{l}\text { Prod } \\
\text { (ii) }\end{array}$ & $\begin{array}{c}\text { Gr rate } \\
\text { (iii) }\end{array}$ & $\begin{array}{c}\text { Gr rate } \\
\text { (iv) }\end{array}$ & $\begin{array}{c}\text { Prod } \\
(\mathrm{v})\end{array}$ & $\begin{array}{c}\text { Gr rate } \\
\text { (vi) }\end{array}$ \\
\hline Dt0 & $\begin{array}{c}0.016^{* * *} \\
(0.003)\end{array}$ & $\begin{array}{c}0.013^{* * *} \\
(0.003)\end{array}$ & $\begin{array}{c}-0.013^{* * *} \\
(0.002)\end{array}$ & $\begin{array}{c}-0.015^{* * *} \\
(0.003)\end{array}$ & $\begin{array}{c}0.021^{* * *} * \\
(0.007)\end{array}$ & $\begin{array}{c}0.000 \\
(0.007)\end{array}$ \\
\hline Dt1 & $\begin{array}{c}0.013^{* * *} \\
(0.003)\end{array}$ & $\begin{array}{c}0.013^{* * *} \\
(0.003)\end{array}$ & $\begin{array}{c}0.001 \\
(0.003)\end{array}$ & $\begin{array}{c}0.003 \\
(0.003)\end{array}$ & $\begin{array}{l}0.013^{*} \\
(0.007)\end{array}$ & $\begin{array}{c}0.008 \\
(0.007)\end{array}$ \\
\hline Dt2 & $\begin{array}{c}0.011 * * * \\
(0.003)\end{array}$ & $\begin{array}{c}0.009^{* * *} * \\
(0.003)\end{array}$ & $\begin{array}{c}0.001 \\
(0.003)\end{array}$ & $\begin{array}{l}-0.001 \\
(0.003)\end{array}$ & $\begin{array}{c}0.003 \\
(0.008)\end{array}$ & $\begin{array}{l}-0.003 \\
(0.008)\end{array}$ \\
\hline DBefore & $\begin{array}{c}0.015^{* * *} \\
(0.002)\end{array}$ & $\begin{array}{c}0.017^{* * *} * \\
(0.002)\end{array}$ & $\begin{array}{c}-0.005^{* *} \\
(0.002)\end{array}$ & $\begin{array}{l}-0.003 \\
(0.002)\end{array}$ & $\begin{array}{c}0.014^{* *} \\
(0.006)\end{array}$ & $\begin{array}{l}-0.002 \\
(0.006)\end{array}$ \\
\hline DLeast & $\begin{array}{c}0.077^{* * *} * \\
(0.006)\end{array}$ & $\begin{array}{c}0.080^{* * *} * \\
(0.006)\end{array}$ & $\begin{array}{c}0.011^{* * *} \\
(0.002)\end{array}$ & $\begin{array}{c}0.010^{* * *} \\
(0.003)\end{array}$ & $\begin{array}{c}0.033^{* * *} \\
(0.012)\end{array}$ & $\begin{array}{c}0.001 \\
(0.006)\end{array}$ \\
\hline DPlant t0 & & $\begin{array}{l}-0.001 \\
(0.004)\end{array}$ & & $\begin{array}{c}-0.009^{* *} \\
(0.004)\end{array}$ & & \\
\hline DPlant t1 & & $\begin{array}{l}-0.003 \\
(0.004)\end{array}$ & & $\begin{array}{c}0.004 \\
(0.004)\end{array}$ & & \\
\hline DPlant t2 & & $\begin{array}{c}0.003 \\
(0.004)\end{array}$ & & $\begin{array}{c}0.010^{* *} \\
(0.004)\end{array}$ & & \\
\hline Year dummies & Yes & Yes & Yes & Yes & Yes & Yes \\
\hline Sector dummies & Yes & Yes & Yes & Yes & Yes & Yes \\
\hline Observations & 147451 & 123040 & 147167 & 122822 & 24726 & 24498 \\
\hline R-squared & 0.132 & 0.130 & 0.004 & 0.004 & 0.123 & 0.006 \\
\hline
\end{tabular}

Notes: Table reports results of regression (random effects) for the impact of investment timing on firm performance, standard errors in parentheses. Asterisks denote significance levels (***: p <1\%; **: p <\% 5\%; * p $<10 \%)$.

purely expansionary investment episodes do not spur an increase in the level of productivity.

Columns (iii), (iv) and (vi) of Table 7 consider productivity growth as the dependent variable. In this respect, it is not possible to detect any effect of investment spikes for Italian firms, contrary to what emerges for France. In this case, column (iii), the positive coefficient on the dummy variable DLeast reveals that the group of investing firms has a higher productivity growth than their counterparts. The results on French firms also helps to learn more on the dynamics of productivity growth after an investment episode. The overall contemporaneous effect of spikes on productivity growth $\left(D_{t 0}+\right.$ DLeast) is slightly negative $\left(-0.02 \mathrm{log}\right.$ points) but becomes positive afterwards: $D_{t 1}+$ DLeast, $D_{t 2}+$ DLeast and DBefore + DLeast have respectively values of $0.011,0.011$ and 0.006 log points. This would suggest that spikes represent a negative shock on productivity growth in the same year, but such negative effect quickly vanishes. The same dynamics is confirmed when controlling for expansionary episodes in column (iv). Our results thus reveal that after a contemporaneous negative shock related to the integration of new capital, a learning process allows to fully exploit the benefits of the investment which translates into higher labor productivity growth.

Among the candidates to explain the lack of such effect for Italy is the pervasive stagnation of the economy during the period. Such a pattern is apparent both at the aggregate (OECD, 2008) and, although to a lesser extent, also at the firm level (Dosi et al., 2012). In addition, the low variability of the dependent variable, labor productivity, for Italy over the period makes it more difficult to clearly identify factors that, even if marginally, did contribute to productivity growth in the Italian manufacturing sector over the last twenty years.

\section{Sales and sales growth}

The positive effect of investment spikes on sales is consistent with the hypothesis of an expansion of sales that follows firms' investment, refer to Table 8. As shown by a positive coefficient on DLeast, 
Table 8: Effect of Investment on Sales and its growth rate

\begin{tabular}{|c|c|c|c|c|c|c|}
\hline & \multicolumn{4}{|c|}{ France } & \multicolumn{2}{|c|}{ Italy } \\
\hline & $\begin{array}{l}\text { Sales } \\
\text { (i) }\end{array}$ & $\begin{array}{l}\text { Sales } \\
\text { (ii) }\end{array}$ & $\begin{array}{c}\text { Gr rate } \\
\text { (iii) }\end{array}$ & $\begin{array}{c}\text { Gr rate } \\
\text { (iv) }\end{array}$ & $\begin{array}{c}\text { Sales } \\
(\mathrm{v})\end{array}$ & $\begin{array}{c}\text { Gr rate } \\
\text { (vi) }\end{array}$ \\
\hline Dt0 & $\begin{array}{c}0.097^{* * *} \\
(0.003)\end{array}$ & $\begin{array}{c}0.083^{* * *} \\
(0.003)\end{array}$ & $\begin{array}{c}0.046^{* *} \\
(0.002)\end{array}$ & $\begin{array}{c}0.042^{* * *} \\
(0.002)\end{array}$ & $\begin{array}{c}0.029^{* * *} \\
(0.006)\end{array}$ & $\begin{array}{c}0.024^{* * *} \\
(0.005)\end{array}$ \\
\hline Dt1 & $\begin{array}{c}0.088^{* * *} \\
(0.003)\end{array}$ & $\begin{array}{c}0.074^{* * *} \\
(0.003)\end{array}$ & $\begin{array}{c}0.004^{* *} \\
(0.002)\end{array}$ & $\begin{array}{l}0.005^{*} \\
(0.002)\end{array}$ & $\begin{array}{l}0.012^{*} \\
(0.007)\end{array}$ & $\begin{array}{c}0.001 \\
(0.006)\end{array}$ \\
\hline Dt2 & $\begin{array}{c}0.070 * * * \\
(0.003)\end{array}$ & $\begin{array}{c}0.058^{* * *} \\
(0.003)\end{array}$ & $\begin{array}{l}-0.003 \\
(0.002)\end{array}$ & $\begin{array}{c}-0.004^{*} \\
(0.002)\end{array}$ & $\begin{array}{c}0.011 \\
(0.007)\end{array}$ & $\begin{array}{c}0.007 \\
(0.006)\end{array}$ \\
\hline DBefore & $\begin{array}{c}0.092^{* * *} \\
(0.003)\end{array}$ & $\begin{array}{c}0.072^{* * *} * \\
(0.002)\end{array}$ & $\begin{array}{c}-0.013^{* *} \\
(0.002)\end{array}$ & $\begin{array}{c}-0.010^{* * *} \\
(0.002)\end{array}$ & $\begin{array}{c}0.002 \\
(0.006)\end{array}$ & $\begin{array}{l}-0.002 \\
(0.004)\end{array}$ \\
\hline DLeast & $\begin{array}{c}0.216^{* * *} \\
(0.015)\end{array}$ & $\begin{array}{c}0.243^{* * *} \\
(0.015)\end{array}$ & $\begin{array}{c}0.028^{* *} \\
(0.002)\end{array}$ & $\begin{array}{c}0.027^{* * *} * \\
(0.002)\end{array}$ & $\begin{array}{c}0.363^{* * *} \\
(0.028)\end{array}$ & $\begin{array}{c}0.013^{* * *} \\
(0.005)\end{array}$ \\
\hline DPlant t0 & & $\begin{array}{c}0.012^{* * *} \\
(0.004)\end{array}$ & & $\begin{array}{c}0.015^{* * *} \\
(0.003)\end{array}$ & & \\
\hline DPlant t1 & & $\begin{array}{c}0.018^{* * *} \\
(0.004)\end{array}$ & & $\begin{array}{c}0.011^{* * *} \\
(0.003)\end{array}$ & & \\
\hline DPlant t2 & & $\begin{array}{c}0.021^{* * *} * \\
(0.004)\end{array}$ & & $\begin{array}{c}0.010^{* * *} \\
(0.013)\end{array}$ & & \\
\hline Year dummies & Yes & Yes & Yes & Yes & Yes & Yes \\
\hline Sector dummies & Yes & Yes & Yes & Yes & Yes & Yes \\
\hline Observations & 148086 & 123549 & 14808 & 123548 & 25008 & 24918 \\
\hline R-squared & 0.139 & 0.139 & 0.025 & 0.022 & 0.088 & 0.015 \\
\hline
\end{tabular}

Notes: Table reports results of regression (random effects) for the impact of investment timing on firm performance, standard errors in parentheses. Asterisks denote significance levels (***: p <1\%; **: p <\% 5\%; * p $<10 \%)$.

columns (i) and (v), firms that have invested at least once in the period have relatively higher sales in both countries, where the effect on French firms is $0.22 \log$ points ( 25 percent) and is relatively higher on Italian firms, $0.36 \log$ points (43 percent). The overall contemporaneous effect of having a spike on the level of sales $\left(D t_{0}+D\right.$ Least $)$ is even larger in both countries (0.31 log points in France and 0.39 in Italy). If such increase in the level of sales is maintained over time for France, as $D_{t 1}, D_{t 2}$ and $D B e$ fore are positive and significant, it decreases for Italy where only the coefficient on $D t 1$ is significant, although much lower than the contemporaneous one. This evidence is rather robust as it still holds when controlling for increases in number of plants, column (ii). In this respect, note that the increase in the number of plants, that we associate with "pure" expansionary events, is systematically related to a greater increase of sales, than for a 'simple' spike.

When considering first differences of sales in both countries, columns (iii) and (vi) of Table 8, firms having invested at least once during the sample period enjoy higher sales growth than their noninvesting counterparts. The effect of having invested is strongest in year $t$ (values of $D_{t 0}+D$ Least are $0.07 \mathrm{log}$ points for France and 0.04 for Italy) and decreases afterwards. Note that if the coefficient on $D B e f o r e$ is negative in the French case, the overall impact of spikes on sales growth is still positive two years after the event (Dleast + Dbefore). Expansionary episodes of French firms contribute to further increase sales growth both contemporaneously and at all lags considered, refer to column (iv).

This third set of results shows that investment spikes not only enable the firm to spur its productivity but also its capacity, as proxied above by the level of sales. Moreover, we do not observe a lag between the investment and the impact on revenues, on the contrary the greatest effect on firm growth is in the same year of the investment episode. 
Table 9: Effect of Investment on Employment and its growth rate

\begin{tabular}{|c|c|c|c|c|c|c|}
\hline & \multicolumn{4}{|c|}{ France } & \multicolumn{2}{|c|}{ Italy } \\
\hline & $\begin{array}{c}\text { Empl } \\
\text { (i) }\end{array}$ & $\begin{array}{l}\text { Empl } \\
\text { (ii) }\end{array}$ & $\begin{array}{c}\text { Gr rate } \\
\text { (iii) }\end{array}$ & $\begin{array}{c}\text { Gr rate } \\
\text { (iv) }\end{array}$ & $\begin{array}{c}\text { Empl } \\
(\mathrm{v})\end{array}$ & $\begin{array}{c}\text { Gr rate } \\
\text { (vi) }\end{array}$ \\
\hline Dt0 & $\begin{array}{c}0.071^{* * * *} \\
(0.002)\end{array}$ & $\begin{array}{c}0.059^{* * *} \\
(0.002)\end{array}$ & $\begin{array}{c}0.044^{* * *} \\
(0.001)\end{array}$ & $\begin{array}{c}0.040 * * * \\
(0.002)\end{array}$ & $\begin{array}{c}0.017^{* * *} \\
(0.004)\end{array}$ & $\begin{array}{c}0.024^{* * *} \\
(0.003)\end{array}$ \\
\hline Dt1 & $\begin{array}{c}0.071^{* * *} \\
(0.002)\end{array}$ & $\begin{array}{c}0.059^{* * *} * \\
(0.002)\end{array}$ & $\begin{array}{c}0.010^{* * *} \\
(0.002)\end{array}$ & $\begin{array}{c}0.008^{* * *} \\
(0.002)\end{array}$ & $\begin{array}{c}0.018^{* * *} \\
(0.005)\end{array}$ & $\begin{array}{c}0.008^{* * *} \\
(0.003)\end{array}$ \\
\hline Dt2 & $\begin{array}{c}0.057^{* * *} * \\
(0.002)\end{array}$ & $\begin{array}{c}0.046^{* * * *} \\
(0.002)\end{array}$ & $\begin{array}{c}-0.003^{*} \\
(0.002)\end{array}$ & $\begin{array}{c}-0.004^{* *} \\
(0.002)\end{array}$ & $\begin{array}{c}0.013^{* * *} \\
(0.005)\end{array}$ & $\begin{array}{c}0.001 \\
(0.003)\end{array}$ \\
\hline DBefore & $\begin{array}{c}0.077^{* * *} * \\
(0.002)\end{array}$ & $\begin{array}{c}0.059^{* * *} * \\
(0.002)\end{array}$ & $\begin{array}{c}-0.009^{* * *} \\
(0.001)\end{array}$ & $\begin{array}{c}-0.006^{* * *} \\
(0.001)\end{array}$ & $\begin{array}{c}0.015^{* * *} \\
(0.004)\end{array}$ & $\begin{array}{c}-0.007^{* * *} \\
(0.003)\end{array}$ \\
\hline DLeast & $\begin{array}{c}0.082^{* * * *} \\
(0.012)\end{array}$ & $\begin{array}{c}0.102^{* * *} \\
(0.012)\end{array}$ & $\begin{array}{c}0.020^{* * * *} \\
(0.001)\end{array}$ & $\begin{array}{c}0.020^{* * *} \\
(0.002)\end{array}$ & $\begin{array}{c}0.322^{* * *} \\
(0.020)\end{array}$ & $\begin{array}{c}0.008^{* *} \\
(0.003)\end{array}$ \\
\hline DPlant t0 & & $\begin{array}{c}0.017^{* * *} \\
(0.003)\end{array}$ & & $\begin{array}{c}0.017^{* * *} * \\
(0.002)\end{array}$ & & \\
\hline DPlant t1 & & $\begin{array}{c}0.019 * * * \\
(0.003)\end{array}$ & & $\begin{array}{l}0.004^{*} \\
(0.002)\end{array}$ & & \\
\hline DPlant t2 & & $\begin{array}{c}0.019^{* * *} \\
(0.003)\end{array}$ & & $\begin{array}{c}0.004 \\
(0.007)\end{array}$ & & \\
\hline Year dummies & Yes & Yes & Yes & Yes & Yes & Yes \\
\hline Sector dummies & Yes & Yes & Yes & Yes & Yes & Yes \\
\hline Observations & 148060 & 123529 & 148036 & 123510 & 25879 & 25879 \\
\hline R-squared & 0.062 & 0.064 & 0.028 & 0.027 & 0.053 & 0.0012 \\
\hline
\end{tabular}

Notes: Table reports results of regression (random effects) for the impact of investment timing on firm performance, standard errors in parentheses. Asterisks denote significance levels (***: p <1\%; **: p <\% 5\%; $:$ p $<10 \%)$.

\section{Number of employees and growth rates}

Results for employment are much coherent with our findings on sales as we find that investment spikes are positively related with employment. DLeast, the variable which identifies the group of investing firms, has a positive and significant coefficient for all specifications of Table 9, both for France and Italy. Employment is positively affected by an investment spike, and such effect persists for more than two years in both countries, as also the coefficient on DBefore is significant and positive. The second model specification for France, column (ii), shows that also expansionary events, as the opening of a new plant, contribute positively to employment. Such positive effects is present both in the same year and at all lags considered.

The results on the effect of investment spikes on employment growth (columns iii, iv and vi) are also coherent with the findings on sales growth. First, in both countries investing firms enjoy a higher employment growth rate than the group of non investing firms (DLeast). Second, both countries display a positive contemporaneous effect, with an overall impact $\left(D_{t 0}+\right.$ DLeast $)$ of $0.06 \log$ points in France and 0.03 in Italy. After the first year the impact decreases but remains positive in the long run. Also an increase in the number of plants (column iv), is associated with higher growth rates of employment both in the same year and at all lags considered.

The investigation of the effects of investment spikes on firms' employment decisions provides similar results to the impact on sales. We observe a net increase in employment contemporaneous to the investment spike, and such effect is also detected in the case of expansionary episodes such as the opening of a new plant. This result points to a substantial complementarity of the capital and labor inputs in the production process at the firm level, with an increase in employment both before and after the adjustment in capital. 


\section{Results at the sectoral level}

Results in Tables 6 to 9 consider the whole sample of firms available for France and Italy and control for differences across industries by means of sectoral dummies. Tables from 13 to 19 in the Appendix report results for those regressions performed on the four sectoral subsamples.

When considering the entire French sample, return on sales was positively affected by investment spikes, even after controlling for the effect of being an investor, at all time lags. No effect was detected for Italian firms, refer to Table 6, columns (i) and (iii)). Further, we showed a negative impact of setting up a new plant on profitability, column (ii). When considering a more disaggregated level of analysis, see Table 13, we find that investing firms in the Italian supplier-dominated (including for example Textiles) and specialized suppliers (including for instance machine-tools firms) sectors are more profitable than non-investing ones. In the latter sector the positive impact appears both at times $t$ and $t-1$. Quite interestingly, also in the French case, investment spikes have a stronger and longer impact in the supplier-dominated and specialized suppliers sectors. In contrast, in the French science-based sector we only find a contemporaneous positive coefficient, and investing and non investing firms do not show any significant differences in terms of their return on sales. We also confirm the negative shock on firm's profitability after the opening of a new plant, especially in the French supplier dominated and scale-intensive sectors. Instead in the science based sector we observe a positive impact two years after the opening of a new plant.

Overall, the impact of investment spikes on firms' profitability seems robust across sectors although the length of the effect varies. Indeed, the supplier-dominated and specialized suppliers sectors report a net increase in their return on sales still several years after a spike in the French case. In turn, the impact is the weakest in the science-based sector.

As for labor productivity, Table 14 displays for France a positive effect of investment spikes thus confirming results at the aggregate level, Table 6 . Two sectors show a diverging pattern however. First, in the science-based sector we do not find any impact of spikes besides the "fixed effect" of being an investor. Opening a new plant does not have any impact on the productivity level. ${ }^{33}$ In the case of Italy, results at the sectoral level are are consistent with the positive fixed and contemporaneous effects found at the aggregate level except for the science-based sector, in which we find no significant impact of spikes on productivity.

At first, one might have expected a stronger impact of investment on productivity in the sciencebased sector, due to higher returns from investments, and a weaker impact in the scale-intensive sector, where investments might be driven by capacity expansion. Instead, we find that science-based firms' productivity is not much affectted by investments, while expansionary investments in the scaleintensive sector enhance productivity. One possible interpretation is that gains in productivity for firms in the science-based sector are more related to intangible assets or skilled workforce than they are related to investment in tangible assets. The opposite is true for the scale-intensive sector, where increasing the number of operating plants and investing allows for further gains in productivity due to scale economies.

Table 15 validates the findings at the aggregate level about the link between investment spikes and productivity growth. We observe a short-term negative shock in the French supplier-dominated and scale-intensive sectors and a positive effect of belonging to the group of investing firms for the French supplier-dominated sector. At the aggregate level the impact of setting up a new plant is first negative at time $t$ then positive two years after. Such pattern is confirmed only in the supplier dominated group, and no impact is observed in the other ones. In the case of Italy, no impact was detected at the aggregate level, and also looking at sectors separately, one only finds a positive contemporaneous relation in the scale-intensive sector, and a negative two year lag relation in the specialized suppliers group.

Finally, Tables 16 to 19 almost perfectly mirror Table 8 and 9 on the link between investment

\footnotetext{
${ }^{33}$ Notice however, that in such case, adding an interacted dummy for the joint occurrence of an investment spike and the opening of a new plant reveals relevant here. Results, not shown here, report that when increasing its number of plants, an investing firm in the supplier dominated group is relatively less productive one year after the spike. Instead in the scale intensive sector, investing firms opening a new plant are relatively more productive at time $t$. Indeed in this latter group, expansionary investments allow for economies of scale and reduce costs.
} 
spikes and sales, sales growth, employment as well as employment growth. Investment allows for increases in size, as measured in terms of sales and number of employees, in all sectors although for French firms the benefits persists for a longer period.

For most of the cases analyzed above the results at the aggregate level still hold when looking separately at Pavitt sectors. At the same time it is also possible to identify some differences. In particular, firms in the scale-intensive sector appear to gain most from setting up a new plant and such result supports the conjecture that for this sector scale-economies are more relevant than in other sectors.

\section{Conclusions}

The present paper examines the pattern of firm-level investments in France and Italy. We investigate what characteristics make it more likely for a business company to invest and what are the effects on firm performance after an investment spike has taken place. Using data on the acquisition of tangible assets we also provide the first large scale study that documents for France and Italy the lumpy nature of investments, thus confirming previous findings for other countries (see, among the others Doms and Dunne, 1998; Nilsen et al., 2009).

The paper contributes to the methodology for identifying an investment spike, thus enabling the researcher to disentangle repair and maintenance episodes from large adjustments in the stock of tangible assets. In this respect, we introduce a measure for investment spikes, named kernel rule, that provides both a better correction for the size dependence than other methods and also retains all the desired properties a spike measure is required to have. Our proposed measure captures indeed investments events that are large across companies in the same size class, and at the same time it accounts for a large share of aggregate investment.

The analysis of the determinants of investment spikes emphasizes many similarities between the two countries. Fast growing, profitable and productive firms display a higher probability to invest both in France and Italy. The probability to observe an investment spike is higher when there have been other investment episodes in the previous years, but such positive effect decreases over time. Further, the export status is not systematically associated with a higher probability to invest.

Most of the differences between France and Italy emerge in the investigation of firms' performance following an investment spike. The impact of investment on Italian firms is indeed more nuanced for most indicators. We document differences in performance between the group of investing and noninvesting firms and such gap is always significant for French firms. The profit rate, productivity, sales and employment levels are higher for the category of firms reporting investment spikes. In addition to this sort of "fixed effect" for investing firms, one also observes a positive net effect in the year of the investmnent, with the sole exception of productivity growth. The availability, for France only, of the firms' number of plants enables to investigate also the pattern of firm performance after an increase in the number of plants. The latter event, which captures "expansionary" investment episodes, exerts a negative effect on profitability, while the setting up of a new plant is associated with higher sales and employment levels. 


\section{References}

Angelini, P. and Generale, A. (2008). On the evolution of firm size distributions, American Economic Review 98(1): 426-438.

Asphjell, M., Letterie, W., G.A., P. and Nilsen, O. (2010). Sequentiality versus simultaneity: Interrelated factor demand, NHH Department of Economics Discussion Paper 29/2010, IZA.

Audretsch, D. B. and Elston, J. A. (2002). Does firm size matter? Evidence on the impact of liquidity constraints on firm investment behavior in Germany, International Journal of Industrial Organization 20(1): 1-17.

Bernard, A. B., Eaton, J., Jensen, J. B. and Kortum, S. S. (2003). Plants and productivity in international trade, American Economic Review 93(4): 1268-1290.

Bessen, J. E. (1999). New plants as natural experiments in economic adjustment: Adjustment costs, learning-by-doing and lumpy investment, Working paper, Boston University.

Bigsten, A., Collier, P., Dercon, S., Fafchamps, M., Gauthier, B., Gunning, J., Oostendorp, R., Pattillo, C., Soderbom, M. and Teal, F. (2005). Adjustment costs and irreversibility as determinants of investment: Evidence from African manufacturing, Contributions to Economic Analysis and Policy 4(1): 1-27.

Bokpin, G. and Onumah, J. (2009). An empirical analysis of the determinants of corporate investment decisions: Evidence from emerging market firms, International Research Journal of Finance and Economics 33: 134-141.

Bond, S., Elston, J. A., Mairesse, J. and Mulkay, B. (2003). Financial factors of investment in Belgium, France, Germany, and the United Kingdom: a comparison using company data, Review of Economics and Statistics 85(1): 153-165.

Bontempi, E., Boca, A. D., Franzosi, A., Galeotti, M. and Rota, P. (2004). Capital heterogeneity: Does it matter? Fundamental Q and investment on a panel of Italian firms, The RAND Journal of Economics 35: 674-690.

Bottazzi, G., Secchi, A. and Tamagni, F. (forthcoming). Financial constraints and firm dynamics, Small Business Economics . DOI: 10.1007/s11187-012-9465-5.

Brier, G. W. (1950). Verification of forecasts expressed in terms of probability, Monthly Weather Review 78(1): 1-3.

Carlsson, M. and Laséen, S. (2005). Capital adjustment patterns in Swedish manufacturing firms: What model do they suggest?, Economic Journal 115(506): 969-986.

Chatelain, J.-B., Generale, A., Hernando, I., von Kalckreuth, U. and Vermeulen, P. (2003). New findings on firm investment and monetary policy transmission in the euro area, Oxford review of Economic Policy 19(1): 1-11.

Cooper, R., Haltiwanger, J. and Power, L. (1999). Machine replacement and the business cycle: Lumps and bumps, American Economic Review 89: 921-46.

De Long, J. B. and Summers, L. H. (1991). Equipment investment and economic growth, The Quarterly Journal of Economics 106(2): 445-502.

Del Boca, A., Galeotti, M., Himmelberg, C. P. and Rota, P. (2008). Investment and time to plan and build: A comparison of structures vs. equipment in a panel of Italian firms, Journal of the European Economic Association 6(4): 864-889.

Del Boca, A., Galeotti, M. and Rota, P. (2008). Non-convexities in the adjustment of different capital inputs: A firm-level investigation, European Economic Review 52(2): 315-337. 
Doms, M. and Dunne, T. (1998). Capital adjustment patterns in manufacturing plants, Review of Economic Dynamics 1: 409-29.

Dosi, G., Gambardella, A., Grazzi, M. and Orsenigo, L. (2008). Technological revolutions and the evolution of industrial structures: Assessing the impact of new technologies upon the size and boundaries of firms, Capitalism and Society $\mathbf{3}(1)$.

Dosi, G., Grazzi, M., Tomasi, C. and Zeli, A. (2012). Turbulence underneath the big calm: what is happening behind the flat trend of productivity in Italy, Small Business Economics Journal 39(4): 1043-1067.

Doyle, J. and Whited, T. (2001). Fixed costs of adjustment, coordination, and industry investment, The Review of Economics and Statistics 83: 628-637.

Duhautois, R. and Jamet, S. (2001). Hétérogénéité des comportements d'investissement et fluctuations de l'investissement aggrégé, Economie et Prévisions 2001/3: 103-115.

Federer, J. (1993). The impact of uncertainty on aggregate investment spending: An empirical analysis, Journal of Money, Credit and Banking 25(1): 30-48.

Gibrat, R. (1931). Les inègalitès èconomiques, Librairie du Recuil Sirey, Paris.

Gourio, F. and Kashyap, A. K. (2007). Investment spikes: New facts and a general equilibrium exploration, Journal of Monetary Economics 54(Supplement): 1-22.

Grazzi, M., Sanzo, R., Secchi, A. and Zeli, A. (2009). Micro.3 some notes on the development of the integrated system of data 1989-2004, Documenti n. 11, Istat.

Hall, B. H., Mairesse, J., Branstetter, L. and Crepon, B. (1999). Does cash flow cause investment and R\&D: An exploration using panel data for French, Japanese, and United States scientific firms, Finance 9902005, EconWPA.

Huggett, M. and Ospina, S. (2001). Does productivity growth fall after the adoption of new technology?, Journal of Monetary Economics 48(1): 173-195.

Jensen, J. B., McGuckin, R. H. and Stiroh, K. J. (2001). The impact of vintage and survival on productivity: Evidence from cohorts of U.S. manufacturing plants, The Review of Economics and Statistics 83(2): 323-332.

Licandro, O., Maroto, R. and Puch, L. (2004). Innovation, investment and productivity: evidence from spanish firms, Research paper in Economics ECO2004/07, European University Institute.

López, R. A. (2009). Do firms increase productivity in order to become exporters?, Oxford Bulletin of Economics and Statistics 71(5): 621-642.

Mairesse, J., Hall, B. H. and Mulkay, B. (1999). Firm-level investment in France and the United States: An exploration of what we have learned in twenty years, Annales d'Economie et de Statistique 55/56: $27-67$.

Melitz, M. J. (2003). The impact of trade on intra-industry reallocations and aggregate industry productivity, Econometrica 71(6): 1695-1725.

Nilsen, O. A., Raknerud, A., Rybalka, M. and Skjerpen, T. (2009). Lumpy investments, factor adjustments, and labour productivity, Oxford Economic Papers 61(1): 104-127.

Nilsen, O. A. and Schiantarelli, F. (2003). Zeros and lumps in investment: Empirical evidence on irreversibilities and nonconvexities, The Review of Economics and Statistics 85(4): 1021-1037.

OECD (2008). Compendium of Productivity Indicators, OECD Publishing. 
Oliveira, B. and Fortunato, A. (2006). Firm growth and liquidity constraints: A dynamic analysis, Small Business Economics 27(2): 139-156.

Parisi, M. L., Schiantarelli, F. and Sembenelli, A. (2006). Productivity, innovation and R\&D: Micro evidence for Italy, European Economic Review 50(8): 2037-2061.

Pavitt, K. (1984). Sectoral pattern of technical change: Towards a taxonomy and a theory, Research Policy 13: 343-373.

Power, L. (1998). The missing link: Technology, investment, and productivity, The Review of Economics and Statistics 80(2): 300-313.

Sakellaris, P. (2004). Patterns of plant adjustment, Journal of Monetary Economics 51(2): 425-450.

Schiantarelli, F. (1996). Financial constraints and investment: Methodological issues and international evidence, Oxford Review of Economic Policy 12(2): 70-89.

Shima, K. (2010). Lumpy capital adjustment and technical efficiency, Economics Bulletin 30: 28172824.

Silverman, B. W. (1986). Density Estimation for Statistics and Data Analysis, London: Chapman \& Hall/CRC.

Smolny, W. (2003). Determinants of innovation behaviour and investment estimates for West-German manufacturing firms, Economics of Innovation and New Technology 12(5): 449-465.

Stanley, M., Amaral, L., Buldyrev, S., Havlin, S., Leschhorn, H., Maass, P., Salinger, M. and Stanley, H. (1996). Scaling behaviour in the growth of companies, Nature 379: 804-806.

Sutton, J. (1997). Gibrat's legacy, Journal of Economic Literature 35(1): 40-59.

Szulanski, G. (1996). Exploring internal stickiness: Impediments to the transfer of best practice within the firm, Strategic Management Journal 17: 27-43.

Whited, T. M. (1992). Debt, liquidity constraints, and corporate investment: evidence from panel data, Journal of Finance 47(4): 1425-1460.

Whited, T. M. (2006). External finance constraints and the intertemporal pattern of intermittent investment, Journal of Financial Economics 81(3): 467-502. 


\begin{tabular}{|c|c|c|}
\hline Inv. rate & Investment rate & $I_{t} / K_{t-1}$ \\
\hline Empl & Number of employees (log) & $\log \left(E m p l_{t}\right)$ \\
\hline Empl. growth & Growth of employment & $\log \left(E m p l_{t}\right)-\log \left(E m p l_{t-1}\right)$ \\
\hline Prod & Labor Productivity (log) & $\log \left(\operatorname{Prod}_{t}\right)=\log \left(V A_{t} / E m p l_{t}\right)$ \\
\hline Prod. growth & Growth of labor productivity & $\log \left(\operatorname{Prod}_{t}\right)-\log \left(\operatorname{Prod}_{t-1}\right)$ \\
\hline Sales & Total Sales (log) & $\log \left(\right.$ Sales $\left._{t}\right)$ \\
\hline Sales growth & Growth of total sales & $\log \left(\right.$ Sales $\left._{t}\right)-\log \left(\right.$ Sales $\left._{t-1}\right)$ \\
\hline RoS & Return on sales & $\operatorname{RoS}_{t}=$ GOM $_{t} /$ Sales $_{t}$ \\
\hline Plant & Number of plants & \\
\hline Export & Export dummy & $=1$ if Exports $>0$ \\
\hline D1 & Spike dummy & $=1$ if spike at $\mathrm{t}-1$ \\
\hline D2 & Spike dummy & $=1$ if spike at $\mathrm{t}-2$, but not in $\mathrm{t}-1$ \\
\hline D3 & Spike dummy & $=1$ if spike at $\mathrm{t}-3$, but not in $\mathrm{t}-1$ or $\mathrm{t}-2$ \\
\hline Dt0 & Spike dummy & $=1$ if spike at $\mathrm{t}$ \\
\hline Dt1 & Spike dummy & $=1$ if spike at $\mathrm{t}-1$, but not in $\mathrm{t}$ \\
\hline Dt2 & Spike dummy & $=1$ if spike at $\mathrm{t}-2$, but not in $\mathrm{t}-1$ or $\mathrm{t}$ \\
\hline DBefore & Spike dummy & $=1$ if spike occurred before $\mathrm{t}-2$ \\
\hline DLeast & Spike dummy & $=1$ if at least 1 spike in the period \\
\hline DPlant $\mathrm{t}$ & Expansionary inv. dummy & $=1$ if increase in $\mathrm{nb}$ of plants in $\mathrm{t}$ \\
\hline
\end{tabular}

\section{A Appendix}


Table 11: Determinants of Investment by Pavitt sector (column i, ii and v from Table 5).

\begin{tabular}{|c|c|c|c|c|c|c|c|c|c|c|c|c|}
\hline & \multicolumn{8}{|c|}{ France } & \multicolumn{4}{|c|}{ Italy } \\
\hline & \multicolumn{2}{|c|}{$\begin{array}{c}\text { Supplier } \\
\text { Dominated }\end{array}$} & \multicolumn{2}{|c|}{$\begin{array}{c}\text { Scale } \\
\text { Intensive }\end{array}$} & \multicolumn{2}{|c|}{$\begin{array}{c}\text { Specialized } \\
\text { Suppliers }\end{array}$} & \multicolumn{2}{|c|}{$\begin{array}{c}\text { Science } \\
\text { Based }\end{array}$} & $\begin{array}{l}\text { Supplier } \\
\text { Domin }\end{array}$ & $\begin{array}{l}\text { Scale } \\
\text { Inten }\end{array}$ & $\begin{array}{l}\text { Specialized } \\
\text { Suppl }\end{array}$ & $\begin{array}{c}\text { Science } \\
\text { Based }\end{array}$ \\
\hline Empl & $\begin{array}{c}0.016^{* * *} \\
(0.001)\end{array}$ & & $\begin{array}{c}0.016^{* * * *} \\
(0.002)\end{array}$ & & $\begin{array}{c}0.013^{* * * *} \\
(0.002)\end{array}$ & & $\begin{array}{c}0.008^{* *} \\
(0.003)\end{array}$ & & $\begin{array}{c}0.024^{* * *} \\
(0.005)\end{array}$ & $\begin{array}{c}0.018^{* * *} \\
(0.004)\end{array}$ & $\begin{array}{c}0.012 \\
(0.008)\end{array}$ & $\begin{array}{c}0.012 \\
(0.009)\end{array}$ \\
\hline Plant & & $\begin{array}{c}0.012^{* * *} \\
(0.002)\end{array}$ & & $\begin{array}{c}0.010^{* *} \\
(0.004)\end{array}$ & & $\begin{array}{c}0.012^{* * *} \\
(0.004)\end{array}$ & & $\begin{array}{l}-0.002 \\
(0.007)\end{array}$ & & & & \\
\hline RoS & $\begin{array}{c}0.219^{* * *} \\
(0.017)\end{array}$ & $\begin{array}{c}0.234^{* * *} \\
(0.017)\end{array}$ & $\begin{array}{c}0.266^{* * * *} \\
(0.027)\end{array}$ & $\begin{array}{c}0.266^{* * *} \\
(0.027)\end{array}$ & $\begin{array}{c}0.266^{* * * *} \\
(0.034)\end{array}$ & $\begin{array}{c}0.266^{* * *} \\
(0.034)\end{array}$ & $\begin{array}{c}0.069^{* * *} \\
(0.040)\end{array}$ & $\begin{array}{l}0.061^{*} \\
(0.037)\end{array}$ & $\begin{array}{c}0.045 \\
(0.066)\end{array}$ & $\begin{array}{c}0.138^{* *} \\
(0.063)\end{array}$ & $\begin{array}{c}0.322^{* * *} \\
(0.100)\end{array}$ & $\begin{array}{c}0.176 \\
(0.139)\end{array}$ \\
\hline Prod & $\begin{array}{c}0.023^{* * *} \\
(0.003)\end{array}$ & $\begin{array}{c}0.017^{* * *} \\
(0.003)\end{array}$ & $\begin{array}{l}-0.010 \\
(0.005)\end{array}$ & $\begin{array}{l}-0.009 \\
(0.005)\end{array}$ & $\begin{array}{c}0.003 \\
(0.008)\end{array}$ & $\begin{array}{c}0.004 \\
(0.008)\end{array}$ & $\begin{array}{c}0.008 \\
(0.008)\end{array}$ & $\begin{array}{c}0.010 \\
(0.008)\end{array}$ & $\begin{array}{c}0.065^{* * *} \\
(0.012)\end{array}$ & $\begin{array}{c}0.022^{* * *} \\
(0.011)\end{array}$ & $\begin{array}{c}0.011 \\
(0.023)\end{array}$ & $\begin{array}{l}-0.045 \\
(0.028)\end{array}$ \\
\hline Export & $\begin{array}{c}-0.007^{* * *} \\
(0.003)\end{array}$ & $\begin{array}{l}-0.001 \\
(0.003)\end{array}$ & $\begin{array}{c}0.015^{* * *} \\
(0.005)\end{array}$ & $\begin{array}{c}0.023^{* * *} \\
(0.005)\end{array}$ & $\begin{array}{c}0.000 \\
(0.006)\end{array}$ & $\begin{array}{c}0.006 \\
(0.006)\end{array}$ & $\begin{array}{c}0.009 \\
(0.010)\end{array}$ & $\begin{array}{c}0.014 \\
(0.009)\end{array}$ & $\begin{array}{c}0.002 \\
(0.014)\end{array}$ & $\begin{array}{r}-0.013 \\
(0.014)\end{array}$ & $\begin{array}{l}-0.022 \\
(0.028)\end{array}$ & $\begin{array}{c}0.076 \\
(0.055)\end{array}$ \\
\hline D1 & $\begin{array}{c}0.124^{* * *} \\
(0.004)\end{array}$ & $\begin{array}{c}0.124^{* * *} \\
(0.004)\end{array}$ & $\begin{array}{c}0.130^{* * *} \\
(0.006)\end{array}$ & $\begin{array}{c}0.128^{* * *} \\
(0.006)\end{array}$ & $\begin{array}{c}0.137^{* * *} \\
(0.008)\end{array}$ & $\begin{array}{c}0.136^{* * *} \\
(0.008)\end{array}$ & $\begin{array}{c}0.161^{* * *} \\
(0.012)\end{array}$ & $\begin{array}{c}0.160^{* * *} \\
(0.012)\end{array}$ & $\begin{array}{c}0.126^{* * *} \\
(0.012)\end{array}$ & $\begin{array}{c}0.112^{* * *} \\
(0.012)\end{array}$ & $\begin{array}{c}0.169 * * * \\
(0.019)\end{array}$ & $\begin{array}{c}0.166^{* * *} \\
(0.024)\end{array}$ \\
\hline D2 & $\begin{array}{c}0.058^{* * *} * \\
(0.004)\end{array}$ & $\begin{array}{c}0.058^{* * *} \\
(0.004)\end{array}$ & $\begin{array}{c}0.063^{* * * *} \\
(0.006)\end{array}$ & $\begin{array}{c}0.061^{* * *} \\
(0.006)\end{array}$ & $\begin{array}{c}0.067^{* * *} \\
(0.008)\end{array}$ & $\begin{array}{c}0.066^{* * *} \\
(0.008)\end{array}$ & $\begin{array}{c}0.075^{* * *} \\
(0.012)\end{array}$ & $\begin{array}{c}0.075^{* * *} \\
(0.012)\end{array}$ & $\begin{array}{c}0.072^{* * *} \\
(0.013)\end{array}$ & $\begin{array}{c}0.065^{* * *} \\
(0.013)\end{array}$ & $\begin{array}{c}0.119 * * * \\
(0.020)\end{array}$ & $\begin{array}{r}0.085^{* * *} \\
(0.033)\end{array}$ \\
\hline D3 & $\begin{array}{c}0.045^{* * *} \\
(0.004)\end{array}$ & $\begin{array}{c}0.045^{* * *} \\
(0.004)\end{array}$ & $\begin{array}{c}0.046^{* * *} \\
(0.007)\end{array}$ & $\begin{array}{c}0.045^{* * *} \\
(0.007)\end{array}$ & $\begin{array}{c}0.059 * * * \\
(0.008)\end{array}$ & $\begin{array}{c}0.058^{* * *} \\
(0.008)\end{array}$ & $\begin{array}{c}0.050^{* * *} \\
(0.014)\end{array}$ & $\begin{array}{c}0.048^{* * *} \\
(0.014)\end{array}$ & $\begin{array}{c}0.072^{* * *} \\
(0.016)\end{array}$ & $\begin{array}{c}0.035^{* *} \\
(0.016)\end{array}$ & $\begin{array}{c}0.092^{* * *} \\
(0.026)\end{array}$ & $\begin{array}{c}0.039 \\
(0.045)\end{array}$ \\
\hline Year dummies & Yes & Yes & Yes & Yes & Yes & Yes & Yes & Yes & Yes & Yes & Yes & Yes \\
\hline Observations & 76221 & 76187 & 30565 & 30562 & 19776 & 19776 & 7232 & 7220 & 7545 & 7806 & 3430 & 1028 \\
\hline Brier score & 0.1103 & 0.1107 & 0.1054 & 0.1062 & 0.1068 & 0.1071 & 0.1025 & 0.1027 & 0.1356 & 0.1369 & 0.1413 & 0.1203 \\
\hline
\end{tabular}

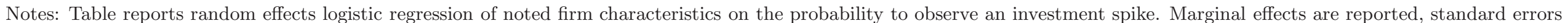
in parentheses. Asterisks denote significance levels (***: p <1\%; **: p<\% 5\%; *: p<10\%). 
Table 12: Determinants of Investment by Pavitt sector (columns iii, iv and vi from Table 5).

\begin{tabular}{|c|c|c|c|c|c|c|c|c|c|c|c|c|}
\hline & \multicolumn{8}{|c|}{ France } & \multicolumn{4}{|c|}{ Italy } \\
\hline & \multicolumn{2}{|c|}{$\begin{array}{c}\text { Supplier } \\
\text { Dominated } \\
\end{array}$} & \multicolumn{2}{|c|}{$\begin{array}{c}\text { Scale } \\
\text { Intensive }\end{array}$} & \multicolumn{2}{|c|}{$\begin{array}{c}\text { Specialized } \\
\text { Suppliers } \\
\end{array}$} & \multicolumn{2}{|c|}{$\begin{array}{c}\text { Science } \\
\text { Based }\end{array}$} & $\begin{array}{c}\text { Supplier } \\
\text { Domin }\end{array}$ & $\begin{array}{l}\text { Scale } \\
\text { Inten } \\
\end{array}$ & $\begin{array}{c}\text { Specialized } \\
\text { Suppl } \\
\end{array}$ & $\begin{array}{c}\text { Science } \\
\text { Based } \\
\end{array}$ \\
\hline Empl & $\begin{array}{c}0.013^{* * *} \\
(0.001)\end{array}$ & & $\begin{array}{c}0.013^{* * *} \\
(0.002)\end{array}$ & & $\begin{array}{c}0.010^{* * *} \\
(0.002)\end{array}$ & & $\begin{array}{c}0.007^{* *} \\
(0.003)\end{array}$ & & $\begin{array}{c}0.023^{* * *} \\
(0.005)\end{array}$ & $\begin{array}{c}0.016^{* * *} \\
(0.004)\end{array}$ & $\begin{array}{c}0.011 \\
(0.008)\end{array}$ & $\begin{array}{c}0.008 \\
(0.010)\end{array}$ \\
\hline Plant & & $\begin{array}{c}0.010^{* * *} \\
(0.002)\end{array}$ & & $\begin{array}{c}0.009^{* *} \\
(0.004)\end{array}$ & & $\begin{array}{l}0.008^{*} \\
(0.004)\end{array}$ & & $\begin{array}{c}-0.001 \\
(0.006)\end{array}$ & & & & \\
\hline RoS & $\begin{array}{c}0.176^{* * *} \\
(0.018)\end{array}$ & $\begin{array}{c}0.187^{* * * *} \\
(0.018)\end{array}$ & $\begin{array}{c}0.230^{* * *} \\
(0.027)\end{array}$ & $\begin{array}{c}0.230^{* * * *} \\
(0.027)\end{array}$ & $\begin{array}{c}0.212^{* * *} \\
(0.035)\end{array}$ & $\begin{array}{c}0.210^{* * * *} \\
(0.035)\end{array}$ & $\begin{array}{c}0.075^{*} \\
(0.039)\end{array}$ & $\begin{array}{l}0.068^{*} \\
(0.039)\end{array}$ & $\begin{array}{c}0.056 \\
(0.070)\end{array}$ & $\begin{array}{c}0.163^{* *} \\
(0.065)\end{array}$ & $\begin{array}{c}0.343^{* * *} \\
(0.102)\end{array}$ & $\begin{array}{c}0.226 \\
(0.145)\end{array}$ \\
\hline Prod & $\begin{array}{c}0.025^{* * *} \\
(0.003)\end{array}$ & $\begin{array}{c}0.021^{* * *} \\
(0.003)\end{array}$ & $\begin{array}{l}-0.004 \\
(0.005)\end{array}$ & $\begin{array}{l}-0.003 \\
(0.005)\end{array}$ & $\begin{array}{c}0.010 \\
(0.008)\end{array}$ & $\begin{array}{c}0.012 \\
(0.008)\end{array}$ & $\begin{array}{c}0.006 \\
(0.008)\end{array}$ & $\begin{array}{c}0.008 \\
(0.008)\end{array}$ & $\begin{array}{c}0.067^{* * *} \\
(0.013)\end{array}$ & $\begin{array}{l}0.021^{*} \\
(0.011)\end{array}$ & $\begin{array}{c}-0.003 \\
(0.024)\end{array}$ & $\begin{array}{c}-0.061^{*} \\
(0.032)\end{array}$ \\
\hline Prod. Growth & $\begin{array}{c}0.006 \\
(0.006)\end{array}$ & $\begin{array}{c}0.006 \\
(0.006)\end{array}$ & $\begin{array}{c}0.003 \\
(0.008)\end{array}$ & $\begin{array}{l}-0.002 \\
(0.008)\end{array}$ & $\begin{array}{c}0.007 \\
(0.013)\end{array}$ & $\begin{array}{c}0.006 \\
(0.012)\end{array}$ & $\begin{array}{c}-0.029^{* *} \\
(0.013)\end{array}$ & $\begin{array}{c}-0.029^{* *} \\
(0.013)\end{array}$ & $\begin{array}{r}-0.009 \\
(0.021)\end{array}$ & $\begin{array}{l}-0.013 \\
(0.017)\end{array}$ & $\begin{array}{l}-0.014 \\
(0.031)\end{array}$ & $\begin{array}{l}-0.008 \\
(0.046)\end{array}$ \\
\hline Sales. Growth & $\begin{array}{c}0.045^{* * *} \\
(0.007)\end{array}$ & $\begin{array}{c}0.045^{* * *} \\
(0.007)\end{array}$ & $\begin{array}{c}0.027^{* * *} \\
(0.009)\end{array}$ & $\begin{array}{c}0.026^{* * *} \\
(0.010)\end{array}$ & $\begin{array}{c}0.012 \\
(0.013)\end{array}$ & $\begin{array}{c}0.013 \\
(0.012)\end{array}$ & $\begin{array}{c}0.114^{* * *} \\
(0.018)\end{array}$ & $\begin{array}{c}0.112^{* * *} \\
(0.018)\end{array}$ & $\begin{array}{c}0.030 \\
(0.028)\end{array}$ & $\begin{array}{c}0.052^{* *} \\
(0.025)\end{array}$ & $\begin{array}{c}0.088^{* * * *} \\
(0.032)\end{array}$ & $\begin{array}{c}0.070 \\
(0.070)\end{array}$ \\
\hline Empl. Growth & $\begin{array}{c}0.071^{* * *} \\
(0.009)\end{array}$ & $\begin{array}{c}0.075^{* * *} \\
(0.009)\end{array}$ & $\begin{array}{c}0.077^{* * *} * \\
(0.014)\end{array}$ & $\begin{array}{c}0.080^{* * *} \\
(0.013)\end{array}$ & $\begin{array}{c}0.114^{* * *} \\
(0.019)\end{array}$ & $\begin{array}{c}0.116^{* * *} \\
(0.019)\end{array}$ & $\begin{array}{c}0.032 \\
(0.025)\end{array}$ & $\begin{array}{c}0.037 \\
(0.025)\end{array}$ & $\begin{array}{r}-0.024 \\
(0.037)\end{array}$ & $\begin{array}{c}0.009 \\
(0.031)\end{array}$ & $\begin{array}{l}-0.024 \\
(0.055)\end{array}$ & $\begin{array}{c}0.082 \\
(0.089)\end{array}$ \\
\hline Export & $\begin{array}{c}-0.005^{* *} \\
(0.003)\end{array}$ & $\begin{array}{l}-0.001 \\
(0.003)\end{array}$ & $\begin{array}{c}0.014^{* * *} \\
(0.005)\end{array}$ & $\begin{array}{c}0.020^{* * *} \\
(0.005)\end{array}$ & $\begin{array}{c}0.000 \\
(0.006)\end{array}$ & $\begin{array}{c}0.004 \\
(0.006)\end{array}$ & $\begin{array}{c}0.008 \\
(0.009)\end{array}$ & $\begin{array}{c}0.012 \\
(0.009)\end{array}$ & $\begin{array}{c}0.004 \\
(0.015)\end{array}$ & $\begin{array}{r}-0.001 \\
(0.015)\end{array}$ & $\begin{array}{c}-0.022 \\
(0.030)\end{array}$ & $\begin{array}{c}0.097 \\
(0.057)\end{array}$ \\
\hline D1 & $\begin{array}{c}0.114^{* * *} \\
(0.004)\end{array}$ & $\begin{array}{c}0.113^{* * *} \\
(0.004)\end{array}$ & $\begin{array}{c}0.124^{* * *} \\
(0.006)\end{array}$ & $\begin{array}{c}0.122^{* * *} \\
(0.006)\end{array}$ & $\begin{array}{c}0.128^{* * *} \\
(0.008)\end{array}$ & $\begin{array}{c}0.128^{* * *} \\
(0.008)\end{array}$ & $\begin{array}{c}0.144^{* * *} \\
(0.013)\end{array}$ & $\begin{array}{c}0.144^{* * *} \\
(0.013)\end{array}$ & $\begin{array}{c}0.123^{* * *} \\
(0.012)\end{array}$ & $\begin{array}{c}0.105^{* * *} \\
(0.012)\end{array}$ & $\begin{array}{c}0.165^{* * *} \\
(0.019)\end{array}$ & $\begin{array}{r}0.148^{* * *} \\
(0.024)\end{array}$ \\
\hline D2 & $\begin{array}{c}0.056^{* * *} \\
(0.004)\end{array}$ & $\begin{array}{c}0.056^{* * *} \\
(0.004)\end{array}$ & $\begin{array}{c}0.063^{* * *} \\
(0.006)\end{array}$ & $\begin{array}{c}0.062^{* * *} \\
(0.006)\end{array}$ & $\begin{array}{c}0.066^{* * *} \\
(0.007)\end{array}$ & $\begin{array}{c}0.066^{* * *} \\
(0.007)\end{array}$ & $\begin{array}{c}0.072^{* * *} \\
(0.012)\end{array}$ & $\begin{array}{c}0.072^{* * *} \\
(0.012)\end{array}$ & $\begin{array}{c}0.069^{* * *} \\
(0.013)\end{array}$ & $\begin{array}{c}0.063^{* * *} \\
(0.013)\end{array}$ & $\begin{array}{c}0.113^{* * *} \\
(0.020)\end{array}$ & $\begin{array}{c}0.081^{* *} \\
(0.032)\end{array}$ \\
\hline D3 & $\begin{array}{c}0.043^{* * *} \\
(0.004)\end{array}$ & $\begin{array}{c}0.044^{* * *} \\
(0.004)\end{array}$ & $\begin{array}{c}0.046^{* * *} \\
(0.007)\end{array}$ & $\begin{array}{c}0.045^{* * *} \\
(0.007)\end{array}$ & $\begin{array}{c}0.059 * * * \\
(0.008)\end{array}$ & $\begin{array}{c}0.058^{* * *} \\
(0.008)\end{array}$ & $\begin{array}{c}0.047^{* * *} \\
(0.013)\end{array}$ & $\begin{array}{c}0.045^{* * *} \\
(0.013)\end{array}$ & $\begin{array}{c}0.071^{* * *} \\
(0.016)\end{array}$ & $\begin{array}{c}0.032 \\
(0.016)\end{array}$ & $\begin{array}{c}0.089^{* * *} \\
(0.025)\end{array}$ & $\begin{array}{c}0.036 \\
(0.043)\end{array}$ \\
\hline Year dummies & Yes & Yes & Yes & Yes & Yes & Yes & Yes & Yes & Yes & Yes & Yes & Yes \\
\hline Observations & 73536 & 73510 & 29551 & 29548 & 19076 & 19076 & 6944 & 6932 & 7168 & 7458 & 3280 & 990 \\
\hline Brier score & 0.1062 & 0.1064 & 0.1012 & 0.1017 & 0.1023 & 0.1025 & 0.0957 & 0.0958 & 0.1329 & 0.1343 & 0.1379 & 0.1167 \\
\hline
\end{tabular}

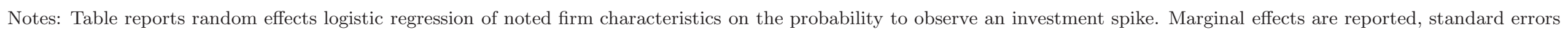
in parentheses. Asterisks denote significance levels (***: p <1\%; **: p<\% 5\%; *: p<10\%). 
Table 13: Effect of Investment on Profitability by Pavitt sector (Table 6)

\begin{tabular}{|c|c|c|c|c|c|c|c|c|c|c|c|c|}
\hline \multirow{3}{*}{$\begin{array}{l}\text { RoS } \\
\text { Dt0 }\end{array}$} & \multicolumn{8}{|c|}{ France } & \multicolumn{4}{|c|}{ Italy } \\
\hline & \multicolumn{2}{|c|}{$\begin{array}{c}\text { Supplier } \\
\text { Dominated }\end{array}$} & \multicolumn{2}{|c|}{$\begin{array}{c}\text { Scale } \\
\text { Intensive }\end{array}$} & \multicolumn{2}{|c|}{$\begin{array}{c}\text { Specialized } \\
\text { Suppliers }\end{array}$} & \multicolumn{2}{|c|}{$\begin{array}{c}\text { Science } \\
\text { Based }\end{array}$} & \multirow{2}{*}{$\begin{array}{c}\text { Supplier } \\
\text { Domin }\end{array}$} & \multirow{2}{*}{$\begin{array}{c}\begin{array}{c}\text { Scale } \\
\text { Inten }\end{array} \\
0.015 \\
(0.069)\end{array}$} & \multirow{2}{*}{$\begin{array}{c}\begin{array}{c}\text { Specialized } \\
\text { Suppl }\end{array} \\
0.012^{* * *} \\
(0.003)\end{array}$} & \multirow{2}{*}{$\begin{array}{c}\begin{array}{c}\text { Science } \\
\text { Based }\end{array} \\
0.012 \\
(0.008)\end{array}$} \\
\hline & $\begin{array}{c}0.008^{* * *} \\
(0.002)\end{array}$ & $\begin{array}{c}0.005^{* * *} \\
(0.001)\end{array}$ & $\begin{array}{c}0.004^{* *} \\
(0.002)\end{array}$ & $\begin{array}{c}0.005^{* *} \\
(0.002)\end{array}$ & $\begin{array}{c}0.013^{* * *} \\
(0.002)\end{array}$ & $\begin{array}{c}0.014^{* * *} \\
(0.002)\end{array}$ & $\begin{array}{c}0.092^{* *} \\
(0.038)\end{array}$ & $\begin{array}{c}0.068^{* * *} * \\
(0.021)\end{array}$ & & & & \\
\hline Dt1 & $\begin{array}{c}0.008^{* * *} \\
(0.002)\end{array}$ & $\begin{array}{c}0.007^{* * *} \\
(0.001)\end{array}$ & $\begin{array}{c}0.001 \\
(0.002)\end{array}$ & $\begin{array}{c}0.002 \\
(0.002)\end{array}$ & $\begin{array}{c}0.009^{* * *} \\
(0.002)\end{array}$ & $\begin{array}{c}0.012^{* * *} \\
(0.003)\end{array}$ & $\begin{array}{c}0.023 \\
(0.041)\end{array}$ & $\begin{array}{c}0.019 \\
(0.023)\end{array}$ & $\begin{array}{c}0.001 \\
(0.002)\end{array}$ & $\begin{array}{c}0.008 \\
(0.076)\end{array}$ & $\begin{array}{c}0.010^{* * *} \\
(0.003)\end{array}$ & $\begin{array}{c}0.002 \\
(0.008)\end{array}$ \\
\hline Dt2 & $\begin{array}{c}0.004^{* *} \\
(0.002)\end{array}$ & $\begin{array}{c}0.004^{* * *} \\
(0.001)\end{array}$ & $\begin{array}{c}0.002 \\
(0.002)\end{array}$ & $\begin{array}{c}0.002 \\
(0.002)\end{array}$ & $\begin{array}{c}0.007 * * * \\
(0.002)\end{array}$ & $\begin{array}{c}0.007 * * * \\
(0.003)\end{array}$ & $\begin{array}{c}-0.076^{*} \\
(0.041)\end{array}$ & $\begin{array}{c}0.017 \\
(0.023)\end{array}$ & $\begin{array}{l}-0.002 \\
(0.002)\end{array}$ & $\begin{array}{c}0.005 \\
(0.079)\end{array}$ & $\begin{array}{l}-0.000 \\
(0.004)\end{array}$ & $\begin{array}{c}0.005 \\
(0.008)\end{array}$ \\
\hline DBefore & $\begin{array}{c}0.004^{* *} \\
(0.002)\end{array}$ & $\begin{array}{c}0.005^{* * *} \\
(0.001)\end{array}$ & $\begin{array}{c}0.003 \\
(0.002)\end{array}$ & $\begin{array}{c}0.002 \\
(0.002)\end{array}$ & $\begin{array}{c}0.005^{* *} \\
(0.003)\end{array}$ & $\begin{array}{c}0.007 * * * \\
(0.002)\end{array}$ & $\begin{array}{l}0.064^{*} \\
(0.033)\end{array}$ & $\begin{array}{l}-0.007 \\
(0.019)\end{array}$ & $\begin{array}{c}0.001 \\
(0.002)\end{array}$ & $\begin{array}{c}0.012 \\
(0.064)\end{array}$ & $\begin{array}{l}-0.003 \\
(0.003)\end{array}$ & $\begin{array}{c}0.008 \\
(0.007)\end{array}$ \\
\hline DLeast & $\begin{array}{c}0.026^{* * *} \\
(0.002)\end{array}$ & $\begin{array}{c}0.028^{* * *} \\
(0.002)\end{array}$ & $\begin{array}{c}0.020^{* * * *} \\
(0.004)\end{array}$ & $\begin{array}{c}0.021^{* * *} \\
(0.004)\end{array}$ & $\begin{array}{c}0.016^{* * *} \\
(0.004)\end{array}$ & $\begin{array}{c}0.014^{* * *} \\
(0.005)\end{array}$ & $\begin{array}{l}-0.117 \\
(0.074)\end{array}$ & $\begin{array}{l}-0.049 \\
(0.039)\end{array}$ & $\begin{array}{c}0.014^{* * *} \\
(0.003)\end{array}$ & $\begin{array}{c}0.087 \\
(0.083)\end{array}$ & $\begin{array}{c}0.012^{* *} \\
(0.005)\end{array}$ & $\begin{array}{c}0.014 \\
(0.010)\end{array}$ \\
\hline DPlant t0 & & $\begin{array}{c}-0.008^{* * *} \\
(0.002)\end{array}$ & & $\begin{array}{r}-0.002 \\
(0.003)\end{array}$ & & $\begin{array}{c}-0.005^{*} \\
(0.003)\end{array}$ & & $\begin{array}{l}-0.033 \\
(0.026)\end{array}$ & & & & \\
\hline DPlant t1 & & $\begin{array}{c}-0.005^{* * *} \\
(0.002)\end{array}$ & & $\begin{array}{c}-0.010^{* * *} \\
(0.003)\end{array}$ & & $\begin{array}{c}-0.007^{* *} \\
(0.003)\end{array}$ & & $\begin{array}{c}0.034 \\
(0.028)\end{array}$ & & & & \\
\hline DPlant t2 & & $\begin{array}{l}-0.002 \\
(0.002)\end{array}$ & & $\begin{array}{c}-0.007^{* *} \\
(0.003)\end{array}$ & & $\begin{array}{c}-0.007^{* *} \\
(0.003)\end{array}$ & & $\begin{array}{c}0.119 * * * \\
(0.028)\end{array}$ & & & & \\
\hline Year dummies & Yes & Yes & Yes & Yes & Yes & Yes & Yes & Yes & Yes & Yes & Yes & Yes \\
\hline Observations & 84117 & 70256 & 33889 & 28388 & 21945 & 18229 & 8148 & 6686 & 9511 & 9533 & 4168 & 1328 \\
\hline R-squared & 0.008 & 0.020 & 0.012 & 0.012 & 0.012 & 0.013 & 0.001 & 0.001 & 0.031 & 0.001 & 0.026 & 0.021 \\
\hline
\end{tabular}

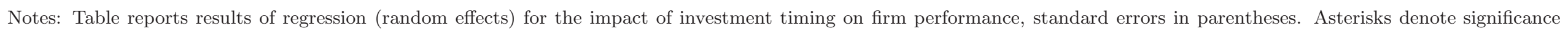
levels (***: $\mathrm{p}<1 \%$; **: $\mathrm{p}<\% 5 \%$; : $\mathrm{p}<10 \%$ ). 
Table 14: Effect of Investment on Productivity by Pavitt sector (Table 7)

\begin{tabular}{|c|c|c|c|c|c|c|c|c|c|c|c|c|}
\hline \multirow{3}{*}{$\begin{array}{c}\text { Prod } \\
\text { Dt0 }\end{array}$} & \multicolumn{8}{|c|}{ France } & \multicolumn{4}{|c|}{ Italy } \\
\hline & \multicolumn{2}{|c|}{$\begin{array}{c}\text { Supplier } \\
\text { Dominated }\end{array}$} & \multicolumn{2}{|c|}{$\begin{array}{c}\text { Scale } \\
\text { Intensive }\end{array}$} & \multicolumn{2}{|c|}{$\begin{array}{c}\text { Specialized } \\
\text { Suppliers }\end{array}$} & \multicolumn{2}{|c|}{$\begin{array}{c}\text { Science } \\
\text { Based }\end{array}$} & \multirow{2}{*}{$\begin{array}{c}\text { Supplier } \\
\text { Domin }\end{array}$} & \multirow{2}{*}{$\begin{array}{c}\text { Scale } \\
\text { Inten } \\
0.030^{* *} \\
(0.012)\end{array}$} & \multirow{2}{*}{$\begin{array}{c}\begin{array}{c}\text { Specialized } \\
\text { Suppl }\end{array} \\
0.042^{* * *} \\
(0.014)\end{array}$} & \multirow{2}{*}{$\begin{array}{c}\begin{array}{r}\text { Science } \\
\text { Based }\end{array} \\
0.049 \\
(0.036)\end{array}$} \\
\hline & $\begin{array}{c}0.016^{* * *} \\
(0.003)\end{array}$ & $\begin{array}{c}0.012^{* * *} \\
(0.004)\end{array}$ & $\begin{array}{c}0.012^{* *} \\
(0.006)\end{array}$ & $\begin{array}{c}0.010 \\
(0.006)\end{array}$ & $\begin{array}{c}0.023^{* *} \\
(0.007)\end{array}$ & $\begin{array}{c}0.025^{* * *} \\
(0.007)\end{array}$ & $\begin{array}{c}0.011 \\
(0.014)\end{array}$ & $\begin{array}{c}0.015 \\
(0.015)\end{array}$ & & & & \\
\hline Dt1 & $\begin{array}{c}0.013^{* * *} \\
(0.003)\end{array}$ & $\begin{array}{c}0.013^{* * *} \\
(0.004)\end{array}$ & $\begin{array}{c}0.009 \\
(0.006)\end{array}$ & $\begin{array}{c}0.010 \\
(0.007)\end{array}$ & $\begin{array}{c}0.016^{* *} \\
(0.007)\end{array}$ & $\begin{array}{c}0.020^{* * *} \\
(0.008)\end{array}$ & $\begin{array}{c}0.018 \\
(0.015)\end{array}$ & $\begin{array}{c}0.001 \\
(0.016)\end{array}$ & $\begin{array}{c}-0.008 \\
(0.011)\end{array}$ & $\begin{array}{c}0.020 \\
(0.013)\end{array}$ & $\begin{array}{c}0.037^{* *} \\
(0.015)\end{array}$ & $\begin{array}{c}0.021 \\
(0.038)\end{array}$ \\
\hline Dt2 & $\begin{array}{c}0.010^{* * *} \\
(0.004)\end{array}$ & $\begin{array}{l}0.007^{*} \\
(0.004)\end{array}$ & $\begin{array}{c}0.006 \\
(0.006)\end{array}$ & $\begin{array}{c}0.005 \\
(0.007)\end{array}$ & $\begin{array}{c}0.017^{* *} \\
(0.007)\end{array}$ & $\begin{array}{c}0.015^{* *} \\
(0.008)\end{array}$ & $\begin{array}{c}0.031 \\
(0.015)\end{array}$ & $\begin{array}{c}0.020 \\
(0.016)\end{array}$ & $\begin{array}{l}-0.011 \\
(0.011)\end{array}$ & $\begin{array}{c}0.009 \\
(0.014)\end{array}$ & $\begin{array}{l}-0.003 \\
(0.016)\end{array}$ & $\begin{array}{c}0.057 \\
(0.038)\end{array}$ \\
\hline DBefore & $\begin{array}{c}0.015^{* * *} \\
(0.003)\end{array}$ & $\begin{array}{c}0.015^{* * *} \\
(0.003)\end{array}$ & $\begin{array}{c}0.028^{* * *} \\
(0.005)\end{array}$ & $\begin{array}{c}0.026 \\
(0.006)\end{array}$ & $\begin{array}{c}0.004 \\
(0.006)\end{array}$ & $\begin{array}{c}0.009 \\
(0.006)\end{array}$ & $\begin{array}{c}0.011 \\
(0.012)\end{array}$ & $\begin{array}{c}0.014 \\
(0.014)\end{array}$ & $\begin{array}{c}-0.002 \\
(0.010)\end{array}$ & $\begin{array}{c}0.026^{* *} \\
(0.012)\end{array}$ & $\begin{array}{c}0.000 \\
(0.014)\end{array}$ & $\begin{array}{c}0.034 \\
(0.033)\end{array}$ \\
\hline DLeast & $\begin{array}{c}0.147^{* * *} \\
(0.008)\end{array}$ & $\begin{array}{c}0.151^{* * *} \\
(0.009)\end{array}$ & $\begin{array}{c}0.039^{* * *} \\
(0.015)\end{array}$ & $\begin{array}{c}0.044^{* * *} \\
(0.016)\end{array}$ & $\begin{array}{c}0.058^{* * *} \\
(0.013)\end{array}$ & $\begin{array}{c}0.055^{* * *} \\
(0.014)\end{array}$ & $\begin{array}{l}0.062^{*} \\
(0.033)\end{array}$ & $\begin{array}{l}0.061^{*} \\
(0.036)\end{array}$ & $\begin{array}{c}0.093^{* * *} \\
(0.020)\end{array}$ & $\begin{array}{c}0.062^{* * *} \\
(0.021)\end{array}$ & $\begin{array}{l}-0.010 \\
(0.027)\end{array}$ & $\begin{array}{l}-0.031 \\
(0.057)\end{array}$ \\
\hline DPlant t0 & & $\begin{array}{l}-0.002 \\
(0.005)\end{array}$ & & $\begin{array}{c}0.003 \\
(0.009)\end{array}$ & & $\begin{array}{l}-0.013 \\
(0.009)\end{array}$ & & $\begin{array}{c}-0.017 \\
(0.018)\end{array}$ & & & & \\
\hline DPlant t1 & & $\begin{array}{l}-0.002 \\
(0.006)\end{array}$ & & $\begin{array}{l}-0.013 \\
(0.010)\end{array}$ & & $\begin{array}{l}-0.012 \\
(0.010)\end{array}$ & & $\begin{array}{c}-0.009 \\
(0.019)\end{array}$ & & & & \\
\hline DPlant $\mathrm{t} 2$ & & $\begin{array}{l}-0.008 \\
(0.006)\end{array}$ & & $\begin{array}{l}-0.008 \\
(0.010)\end{array}$ & & $\begin{array}{l}-0.004 \\
(0.010)\end{array}$ & & $\begin{array}{c}0.015 \\
(0.020)\end{array}$ & & & & \\
\hline Year dummies & Yes & Yes & Yes & Yes & Yes & Yes & Yes & Yes & Yes & Yes & Yes & Yes \\
\hline Observations & 83788 & 69992 & 33716 & 28239 & 21871 & 18174 & 8076 & 6635 & 9458 & 9667 & 4296 & 1305 \\
\hline R2 overall & 0.025 & 0.025 & 0.011 & 0.012 & 0.040 & 0.038 & 0.037 & 0.034 & 0.010 & 0.010 & 0.007 & 0.003 \\
\hline
\end{tabular}

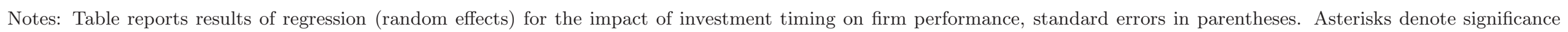
levels (***: $\mathrm{p}<1 \%$; **: $\mathrm{p}<\% 5 \%$; : $\mathrm{p}<10 \%$ ). 
Table 15: Effect of Investment on Productivity Growth by Pavitt sector (Table 7)

\begin{tabular}{|c|c|c|c|c|c|c|c|c|c|c|c|c|}
\hline \multirow{3}{*}{$\begin{array}{l}\text { Gr Prod } \\
\text { Dt0 }\end{array}$} & \multicolumn{8}{|c|}{ France } & \multicolumn{4}{|c|}{ Italy } \\
\hline & \multicolumn{2}{|c|}{$\begin{array}{c}\text { Supplier } \\
\text { Dominated }\end{array}$} & \multicolumn{2}{|c|}{$\begin{array}{c}\text { Scale } \\
\text { Intensive }\end{array}$} & \multicolumn{2}{|c|}{$\begin{array}{c}\text { Specialized } \\
\text { Suppliers }\end{array}$} & \multicolumn{2}{|c|}{$\begin{array}{c}\text { Science } \\
\text { Based }\end{array}$} & \multirow{2}{*}{$\begin{array}{c}\text { Supplier } \\
\text { Domin } \\
-0.017 \\
(0.011)\end{array}$} & \multirow{2}{*}{$\begin{array}{l}\text { Scale } \\
\text { Inten }\end{array}$} & \multirow{2}{*}{$\begin{array}{c}\text { Specialized } \\
\text { Suppl } \\
\\
-0.015 \\
(0.014)\end{array}$} & \multirow{2}{*}{$\begin{array}{r}\begin{array}{c}\text { Science } \\
\text { Based }\end{array} \\
-0.002 \\
(0.031)\end{array}$} \\
\hline & $\begin{array}{c}-0.016^{* * *} \\
(0.003)\end{array}$ & $\begin{array}{c}-0.017^{* * *} \\
(0.004)\end{array}$ & $\begin{array}{c}-0.012^{* *} \\
(0.006)\end{array}$ & $\begin{array}{c}-0.014^{* *} \\
(0.006)\end{array}$ & $\begin{array}{l}-0.005 \\
(0.006)\end{array}$ & $\begin{array}{c}-0.002 \\
(0.007)\end{array}$ & $\begin{array}{l}-0.008 \\
(0.013)\end{array}$ & $\begin{array}{c}-0.0140 \\
(0.015)\end{array}$ & & & & \\
\hline Dt1 & $\begin{array}{l}-0.001 \\
(0.003)\end{array}$ & $\begin{array}{c}0.002 \\
(0.004)\end{array}$ & $\begin{array}{c}0.001 \\
(0.006)\end{array}$ & $\begin{array}{c}0.004 \\
(0.007)\end{array}$ & $\begin{array}{c}0.006 \\
(0.007)\end{array}$ & $\begin{array}{c}0.008 \\
(0.008)\end{array}$ & $\begin{array}{c}0.004 \\
(0.015)\end{array}$ & $\begin{array}{l}-0.001 \\
(0.017)\end{array}$ & $\begin{array}{c}0.010 \\
(0.011)\end{array}$ & $\begin{array}{c}0.007 \\
(0.013)\end{array}$ & $\begin{array}{c}0.001 \\
(0.016)\end{array}$ & $\begin{array}{c}0.008 \\
(0.034)\end{array}$ \\
\hline Dt2 & $\begin{array}{l}-0.003 \\
(0.004)\end{array}$ & $\begin{array}{l}-0.003 \\
(0.004)\end{array}$ & $\begin{array}{c}0.006 \\
(0.006)\end{array}$ & $\begin{array}{c}0.004 \\
(0.007)\end{array}$ & $\begin{array}{c}0.001 \\
(0.008)\end{array}$ & $\begin{array}{c}0.004 \\
(0.008)\end{array}$ & $\begin{array}{c}0.012 \\
(0.015)\end{array}$ & $\begin{array}{c}0.010 \\
(0.017)\end{array}$ & $\begin{array}{c}0.007 \\
(0.012)\end{array}$ & $\begin{array}{r}-0.006 \\
(0.013)\end{array}$ & $\begin{array}{c}-0.032^{*} \\
(0.018)\end{array}$ & $\begin{array}{c}0.003 \\
(0.036)\end{array}$ \\
\hline DBefore & $\begin{array}{c}-0.005^{* *} \\
(0.003)\end{array}$ & $\begin{array}{l}-0.004 \\
(0.003)\end{array}$ & $\begin{array}{c}0.002 \\
(0.005)\end{array}$ & $\begin{array}{c}0.001 \\
(0.005)\end{array}$ & $\begin{array}{c}-0.009^{*} \\
(0.005)\end{array}$ & $\begin{array}{l}-0.004 \\
(0.006)\end{array}$ & $\begin{array}{l}-0.012 \\
(0.011)\end{array}$ & $\begin{array}{l}-0.003 \\
(0.013)\end{array}$ & $\begin{array}{l}-0.004 \\
(0.010)\end{array}$ & $\begin{array}{c}0.005 \\
(0.009)\end{array}$ & $\begin{array}{l}-0.013 \\
(0.012)\end{array}$ & $\begin{array}{l}-0.008 \\
(0.025)\end{array}$ \\
\hline DLeast & $\begin{array}{c}0.012^{* * *} \\
(0.003)\end{array}$ & $\begin{array}{c}0.013^{* * *} \\
(0.003)\end{array}$ & $\begin{array}{c}0.008 \\
(0.005)\end{array}$ & $\begin{array}{c}0.009 \\
(0.006)\end{array}$ & $\begin{array}{c}0.006 \\
(0.005)\end{array}$ & $\begin{array}{c}0.001 \\
(0.006)\end{array}$ & $\begin{array}{c}0.006 \\
(0.012)\end{array}$ & $\begin{array}{l}-0.001 \\
(0.016)\end{array}$ & $\begin{array}{c}0.005 \\
(0.011)\end{array}$ & $\begin{array}{l}-0.002 \\
(0.010)\end{array}$ & $\begin{array}{c}0.009 \\
(0.013)\end{array}$ & $\begin{array}{l}-0.012 \\
(0.026)\end{array}$ \\
\hline DPlant t0 & & $\begin{array}{c}-0.010^{* *} \\
(0.005)\end{array}$ & & $\begin{array}{c}0.000 \\
(0.019)\end{array}$ & & $\begin{array}{l}-0.013 \\
(0.009)\end{array}$ & & $\begin{array}{c}-0.003 \\
(0.018)\end{array}$ & & & & \\
\hline DPlant t1 & & $\begin{array}{c}-0.011^{* *} \\
(0.005)\end{array}$ & & $\begin{array}{l}-0.005 \\
(0.009)\end{array}$ & & $\begin{array}{l}-0.005 \\
(0.010)\end{array}$ & & $\begin{array}{c}0.007 \\
(0.020)\end{array}$ & & & & \\
\hline DPlant t2 & & $\begin{array}{c}0.014^{* *} \\
(0.006)\end{array}$ & & $\begin{array}{c}0.008 \\
(0.009)\end{array}$ & & $\begin{array}{c}0.007 \\
(0.011)\end{array}$ & & $\begin{array}{c}0.010 \\
(0.020)\end{array}$ & & & & \\
\hline Year dummies & Yes & Yes & Yes & Yes & Yes & Yes & Yes & Yes & Yes & Yes & Yes & Yes \\
\hline Observations & 83654 & 69890 & 33634 & 28172 & 21832 & 18142 & 8047 & 6618 & 9383 & 9563 & 4259 & 1293 \\
\hline R2 overall & 0.003 & 0.003 & 0.003 & 0.003 & 0.003 & 0.003 & 0.004 & 0.006 & 0.006 & 0.009 & 0.016 & 0.007 \\
\hline
\end{tabular}

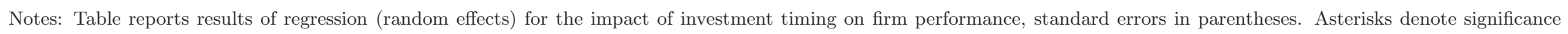
levels (***: $\mathrm{p}<1 \%$; **: $\mathrm{p}<\% 5 \%$; : $\mathrm{p}<10 \%$ ). 
Table 16: Effect of Investment on Sales by Pavitt sector (Table 8)

\begin{tabular}{|c|c|c|c|c|c|c|c|c|c|c|c|c|}
\hline \multirow{3}{*}{$\begin{array}{l}\text { Sales } \\
\text { Dt0 }\end{array}$} & \multicolumn{8}{|c|}{ France } & \multicolumn{4}{|c|}{ Italy } \\
\hline & \multicolumn{2}{|c|}{$\begin{array}{c}\text { Supplier } \\
\text { Dominated }\end{array}$} & \multicolumn{2}{|c|}{$\begin{array}{c}\text { Scale } \\
\text { Intensive }\end{array}$} & \multicolumn{2}{|c|}{$\begin{array}{l}\text { Specialized } \\
\text { Suppliers }\end{array}$} & \multicolumn{2}{|c|}{$\begin{array}{c}\text { Science } \\
\text { Based }\end{array}$} & \multirow{2}{*}{$\begin{array}{c}\begin{array}{c}\text { Supplier } \\
\text { Domin }\end{array} \\
\begin{array}{c}0.023^{* *} \\
(0.010)\end{array}\end{array}$} & \multirow{2}{*}{$\begin{array}{c}\begin{array}{c}\text { Scale } \\
\text { Inten }\end{array} \\
0.024^{* *} \\
(0.010)\end{array}$} & \multirow{2}{*}{$\begin{array}{c}\begin{array}{c}\text { Specialized } \\
\text { Suppl }\end{array} \\
0.050^{* * *} \\
(0.016)\end{array}$} & \multirow{2}{*}{$\begin{array}{c}\begin{array}{c}\text { Science } \\
\text { Based }\end{array} \\
0.073^{* *} \\
(0.030)\end{array}$} \\
\hline & $\begin{array}{c}0.088^{* * *} \\
(0.003)\end{array}$ & $\begin{array}{c}0.073^{* * *} \\
(0.003)\end{array}$ & $\begin{array}{c}0.105^{* * *} \\
(0.005)\end{array}$ & $\begin{array}{c}0.092^{* * *} \\
(0.006)\end{array}$ & $\begin{array}{c}0.098^{* * *} \\
(0.007)\end{array}$ & $\begin{array}{c}0.086^{* * * *} \\
(0.007)\end{array}$ & $\begin{array}{c}0.152^{* * *} \\
(0.013)\end{array}$ & $\begin{array}{c}0.0137^{* * *} \\
(0.014)\end{array}$ & & & & \\
\hline Dt1 & $\begin{array}{c}0.079^{* * *} \\
(0.003)\end{array}$ & $\begin{array}{c}0.065^{* * *} \\
(0.004)\end{array}$ & $\begin{array}{c}0.104^{* * * *} \\
(0.006)\end{array}$ & $\begin{array}{c}0.086^{* * *} \\
(0.006)\end{array}$ & $\begin{array}{c}0.079^{* * *} \\
(0.007)\end{array}$ & $\begin{array}{c}0.076^{* * *} \\
(0.008)\end{array}$ & $\begin{array}{c}0.133^{* * *} \\
(0.014)\end{array}$ & $\begin{array}{c}0.108^{* * *} \\
(0.015)\end{array}$ & $\begin{array}{c}0.010 \\
(0.011)\end{array}$ & $\begin{array}{c}0.000 \\
(0.011)\end{array}$ & $\begin{array}{c}0.036 \\
(0.017)\end{array}$ & $\begin{array}{c}0.049 \\
(0.031)\end{array}$ \\
\hline Dt2 & $\begin{array}{c}0.064^{* * *} \\
(0.003)\end{array}$ & $\begin{array}{c}0.052^{* * *} \\
(0.004)\end{array}$ & $\begin{array}{c}0.083^{* * *} \\
(0.006)\end{array}$ & $\begin{array}{c}0.074^{* * *} \\
(0.006)\end{array}$ & $\begin{array}{c}0.057^{* * *} \\
(0.007)\end{array}$ & $\begin{array}{c}0.037^{* * *} \\
(0.008)\end{array}$ & $\begin{array}{c}0.103^{* * *} \\
(0.014)\end{array}$ & $\begin{array}{c}0.090^{* * *} \\
(0.015)\end{array}$ & $\begin{array}{c}0.001 \\
(0.012)\end{array}$ & $\begin{array}{c}0.014 \\
(0.011)\end{array}$ & $\begin{array}{c}0.019 \\
(0.018)\end{array}$ & $\begin{array}{c}0.037 \\
(0.031)\end{array}$ \\
\hline DBefore & $\begin{array}{c}0.091^{* * * *} \\
(0.003)\end{array}$ & $\begin{array}{c}0.069 * * * \\
(0.003)\end{array}$ & $\begin{array}{c}0.101^{* * * *} \\
(0.005)\end{array}$ & $\begin{array}{c}0.080^{* * *} \\
(0.005)\end{array}$ & $\begin{array}{c}0.077^{* * *} \\
(0.006)\end{array}$ & $\begin{array}{c}0.059^{* * *} \\
(0.007)\end{array}$ & $\begin{array}{c}0.135^{* * *} \\
(0.012)\end{array}$ & $\begin{array}{c}0.106^{* * * *} \\
(0.013)\end{array}$ & $\begin{array}{l}-0.012 \\
(0.010)\end{array}$ & $\begin{array}{c}0.048^{* * *} \\
(0.010)\end{array}$ & $\begin{array}{c}0.030^{* *} \\
(0.015)\end{array}$ & $\begin{array}{c}0.026 \\
(0.027)\end{array}$ \\
\hline DLeast & $\begin{array}{c}0.338^{* * *} \\
(0.019)\end{array}$ & $\begin{array}{c}0.364^{* * *} \\
(0.019)\end{array}$ & $\begin{array}{c}0.172^{* * *} \\
(0.039)\end{array}$ & $\begin{array}{c}0.208^{* * *} \\
(0.038)\end{array}$ & $\begin{array}{c}0.155^{* * *} \\
(0.040)\end{array}$ & $\begin{array}{c}0.172^{* * *} \\
(0.039)\end{array}$ & $\begin{array}{c}0.193^{* * *} \\
(0.084)\end{array}$ & $\begin{array}{c}0.260^{* * *} \\
(0.082)\end{array}$ & $\begin{array}{c}0.355^{* * *} \\
(0.041)\end{array}$ & $\begin{array}{c}0.435^{* * *} \\
(0.049)\end{array}$ & $\begin{array}{c}0.289^{* * *} \\
(0.062)\end{array}$ & $\begin{array}{c}0.394^{* * *} \\
(0.143)\end{array}$ \\
\hline DPlant t0 & & $\begin{array}{l}0.009^{*} \\
(0.005)\end{array}$ & & $\begin{array}{c}0.018^{* *} \\
(0.008)\end{array}$ & & $\begin{array}{c}0.001 \\
(0.009)\end{array}$ & & $\begin{array}{c}0.017 \\
(0.017)\end{array}$ & & & & \\
\hline DPlant t1 & & $\begin{array}{c}0.023^{* * *} \\
(0.005)\end{array}$ & & $\begin{array}{l}0.016^{*} \\
(0.009)\end{array}$ & & $\begin{array}{c}0.004 \\
(0.010)\end{array}$ & & $\begin{array}{c}0.006 \\
(0.019)\end{array}$ & & & & \\
\hline DPlant t2 & & $\begin{array}{c}0.027^{* * *} \\
(0.005)\end{array}$ & & $\begin{array}{c}0.009 \\
(0.009)\end{array}$ & & $\begin{array}{c}0.006 \\
(0.010)\end{array}$ & & $\begin{array}{l}0.033^{*} \\
(0.019)\end{array}$ & & & & \\
\hline Year dummies & Yes & Yes & Yes & Yes & Yes & Yes & Yes & Yes & Yes & Yes & Yes & Yes \\
\hline Observations & 84105 & 70246 & 33889 & 28388 & 21944 & 18229 & 8148 & 6686 & 9541 & 9822 & 4327 & 1318 \\
\hline $\mathrm{R} 2$ overall & 0.034 & 0.035 & 0.017 & 0.019 & 0.016 & 0.014 & 0.020 & 0.022 & 0.030 & 0.032 & 0.018 & 0.012 \\
\hline
\end{tabular}

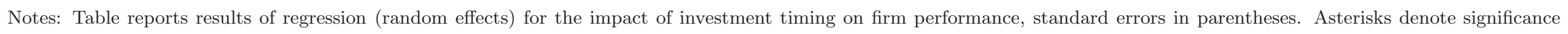
levels (***: $\mathrm{p}<1 \%$; **: $\mathrm{p}<\% 5 \%$; : $\mathrm{p}<10 \%$ ). 
Table 17: Effect of Investment on Sales Growth by Pavitt sector (Table 8)

\begin{tabular}{|c|c|c|c|c|c|c|c|c|c|c|c|c|}
\hline \multirow{3}{*}{$\begin{array}{l}\text { Gr sales } \\
\text { Dt0 }\end{array}$} & \multicolumn{8}{|c|}{ France } & \multicolumn{4}{|c|}{ Italy } \\
\hline & \multicolumn{2}{|c|}{$\begin{array}{c}\text { Supplier } \\
\text { Dominated }\end{array}$} & \multicolumn{2}{|c|}{$\begin{array}{c}\text { Scale } \\
\text { Intensive }\end{array}$} & \multicolumn{2}{|c|}{$\begin{array}{l}\text { Specialized } \\
\text { Suppliers }\end{array}$} & \multicolumn{2}{|c|}{$\begin{array}{c}\text { Science } \\
\text { Based }\end{array}$} & \multirow{2}{*}{ 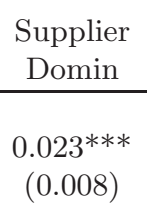 } & \multirow{2}{*}{$\begin{array}{c}\begin{array}{c}\text { Scale } \\
\text { Inten }\end{array} \\
0.025^{* * *} \\
(0.008)\end{array}$} & \multirow{2}{*}{$\begin{array}{c}\begin{array}{c}\text { Specialized } \\
\text { Suppl }\end{array} \\
0.021^{*} \\
(0.013)\end{array}$} & \multirow{2}{*}{$\begin{array}{c}\begin{array}{c}\text { Science } \\
\text { Based }\end{array} \\
0.035 \\
(0.024)\end{array}$} \\
\hline & $\begin{array}{c}0.041^{* * *} \\
(0.003)\end{array}$ & $\begin{array}{c}0.037^{* * * *} \\
(0.003)\end{array}$ & $\begin{array}{c}0.047^{* * *} * \\
(0.004)\end{array}$ & $\begin{array}{c}0.048^{* * *} \\
(0.005)\end{array}$ & $\begin{array}{c}0.051^{* * *} \\
(0.006)\end{array}$ & $\begin{array}{c}0.050^{* * *} \\
(0.006)\end{array}$ & $\begin{array}{c}0.088^{* * *} \\
(0.010)\end{array}$ & $\begin{array}{c}0.068^{* * *} \\
(0.011)\end{array}$ & & & & \\
\hline Dt1 & $\begin{array}{c}0.004 \\
(0.003)\end{array}$ & $\begin{array}{c}0.003 \\
(0.003)\end{array}$ & $\begin{array}{l}0.009^{*} \\
(0.004)\end{array}$ & $\begin{array}{c}0.013^{* * *} \\
(0.005)\end{array}$ & $\begin{array}{c}0.006 \\
(0.006)\end{array}$ & $\begin{array}{c}0.006 \\
(0.007)\end{array}$ & $\begin{array}{c}-0.003 \\
(0.011)\end{array}$ & $\begin{array}{l}-0.009 \\
(0.012)\end{array}$ & $\begin{array}{l}-0.007 \\
(0.009)\end{array}$ & $\begin{array}{c}0.004 \\
(0.008)\end{array}$ & $\begin{array}{c}0.004 \\
(0.014)\end{array}$ & $\begin{array}{c}0.004 \\
(0.026)\end{array}$ \\
\hline Dt2 & $\begin{array}{l}-0.003 \\
(0.003)\end{array}$ & $\begin{array}{l}-0.004 \\
(0.004)\end{array}$ & $\begin{array}{c}0.001 \\
(0.004)\end{array}$ & $\begin{array}{c}0.000 \\
(0.005)\end{array}$ & $\begin{array}{c}-0.013^{*} \\
(0.006)\end{array}$ & $\begin{array}{c}-0.014^{* *} \\
(0.007)\end{array}$ & $\begin{array}{l}-0.008 \\
(0.012)\end{array}$ & $\begin{array}{c}0.004 \\
(0.013)\end{array}$ & $\begin{array}{c}0.019^{* *} \\
(0.010)\end{array}$ & $\begin{array}{c}0.002 \\
(0.009)\end{array}$ & $\begin{array}{l}-0.012 \\
(0.016)\end{array}$ & $\begin{array}{c}0.007 \\
(0.027)\end{array}$ \\
\hline DBefore & $\begin{array}{c}-0.013^{* * *} \\
(0.002)\end{array}$ & $\begin{array}{c}-0.010^{* * *} \\
(0.002)\end{array}$ & $\begin{array}{l}0.003^{*} \\
(0.002)\end{array}$ & $\begin{array}{c}-0.011^{* * *} \\
(0.004)\end{array}$ & $\begin{array}{c}-0.009^{* *} \\
(0.004)\end{array}$ & $\begin{array}{c}-0.004 \\
(0.005)\end{array}$ & $\begin{array}{c}-0.015^{*} \\
(0.008)\end{array}$ & $\begin{array}{l}-0.012 \\
(0.009)\end{array}$ & $\begin{array}{c}-0.015^{* *} \\
(0.007)\end{array}$ & $\begin{array}{l}-0.009 \\
(0.007)\end{array}$ & $\begin{array}{l}-0.002 \\
(0.011)\end{array}$ & $\begin{array}{c}0.005 \\
(0.020)\end{array}$ \\
\hline DLeast & $\begin{array}{c}0.036^{* * *} \\
(0.002)\end{array}$ & $\begin{array}{c}0.034^{* * *} \\
(0.003)\end{array}$ & $\begin{array}{c}0.020^{* * *} \\
(0.004)\end{array}$ & $\begin{array}{c}0.023^{* * *} \\
(0.004)\end{array}$ & $\begin{array}{c}0.020^{* * *} \\
(0.005)\end{array}$ & $\begin{array}{c}0.015^{* * *} \\
(0.005)\end{array}$ & $\begin{array}{c}0.024^{* * *} \\
(0.009)\end{array}$ & $\begin{array}{c}0.031^{* * *} \\
(0.011)\end{array}$ & $\begin{array}{l}0.016^{*} \\
(0.008)\end{array}$ & $\begin{array}{c}0.016^{* *} \\
(0.008)\end{array}$ & $\begin{array}{c}0.009 \\
(0.012)\end{array}$ & $\begin{array}{c}0.000 \\
(0.021)\end{array}$ \\
\hline DPlant t0 & & $\begin{array}{c}0.010^{* *} \\
(0.004)\end{array}$ & & $\begin{array}{c}0.022^{* * *} \\
(0.007)\end{array}$ & & $\begin{array}{c}0.015^{* *} \\
(0.008)\end{array}$ & & $\begin{array}{c}0.019 \\
(0.014)\end{array}$ & & & & \\
\hline DPlant t1 & & $\begin{array}{c}0.019 * * * \\
(0.004)\end{array}$ & & $\begin{array}{c}0.000 \\
(0.007)\end{array}$ & & $\begin{array}{c}0.007 \\
(0.009)\end{array}$ & & $\begin{array}{l}-0.007 \\
(0.015)\end{array}$ & & & & \\
\hline DPlant t2 & & $\begin{array}{c}0.011^{* *} \\
(0.012)\end{array}$ & & $\begin{array}{c}0.004 \\
(0.007)\end{array}$ & & $\begin{array}{c}0.004 \\
(0.009)\end{array}$ & & $\begin{array}{c}0.020 \\
(0.015)\end{array}$ & & & & \\
\hline Year dummies & Yes & Yes & Yes & Yes & Yes & Yes & Yes & Yes & Yes & Yes & Yes & Yes \\
\hline Observations & 84105 & 70246 & 33889 & 28388 & 21943 & 18228 & 8148 & 6686 & 9513 & 9794 & 4298 & 1313 \\
\hline $\mathrm{R} 2$ overall & 0.020 & 0.017 & 0.022 & 0.019 & 0.019 & 0.016 & 0.034 & 0.029 & 0.013 & 0.011 & 0.026 & 0.018 \\
\hline
\end{tabular}

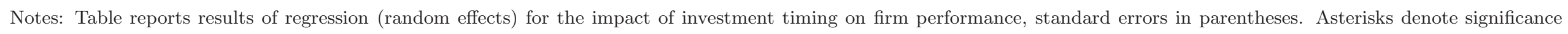
levels (***: $\mathrm{p}<1 \%$; **: $\mathrm{p}<\% 5 \%$; : $\mathrm{p}<10 \%$ ). 
Table 18: Effect of Investment on Employment by Pavitt sector (Table 9)

\begin{tabular}{|c|c|c|c|c|c|c|c|c|c|c|c|c|}
\hline \multirow{3}{*}{$\begin{array}{l}\text { Empl } \\
\text { Dt0 }\end{array}$} & \multicolumn{8}{|c|}{ France } & \multicolumn{4}{|c|}{ Italy } \\
\hline & \multicolumn{2}{|c|}{$\begin{array}{c}\text { Supplier } \\
\text { Dominated }\end{array}$} & \multicolumn{2}{|c|}{$\begin{array}{c}\text { Scale } \\
\text { Intensive }\end{array}$} & \multicolumn{2}{|c|}{$\begin{array}{c}\text { Specialized } \\
\text { Suppliers } \\
\end{array}$} & \multicolumn{2}{|c|}{$\begin{array}{c}\text { Science } \\
\text { Based }\end{array}$} & \multirow{2}{*}{$\begin{array}{c}\begin{array}{c}\text { Supplier } \\
\text { Domin }\end{array} \\
0.022^{* * *} \\
(0.007)\end{array}$} & \multirow{2}{*}{$\begin{array}{c}\text { Scale } \\
\text { Inten } \\
0.010 \\
(0.007)\end{array}$} & \multirow{2}{*}{$\begin{array}{c}\begin{array}{c}\text { Specialized } \\
\text { Suppl }\end{array} \\
0.012 \\
(0.010)\end{array}$} & \multirow{2}{*}{$\begin{array}{c}\begin{array}{c}\text { Science } \\
\text { Based }\end{array} \\
0.061^{* * *} \\
(0.023)\end{array}$} \\
\hline & $\begin{array}{c}0.063^{* * *} \\
(0.003)\end{array}$ & $\begin{array}{c}0.054^{* * *} \\
(0.003)\end{array}$ & $\begin{array}{c}0.078^{* * *} \\
(0.004)\end{array}$ & $\begin{array}{c}0.063^{* * *} \\
(0.004)\end{array}$ & $\begin{array}{c}0.079^{* * *} \\
(0.005)\end{array}$ & $\begin{array}{c}0.064^{* * *} \\
(0.005)\end{array}$ & $\begin{array}{c}0.103^{* * *} \\
(0.009)\end{array}$ & $\begin{array}{c}0.096^{* * *} \\
(0.010)\end{array}$ & & & & \\
\hline Dt1 & $\begin{array}{c}0.065^{* * *} \\
(0.003)\end{array}$ & $\begin{array}{c}0.053^{* * *} \\
(0.003)\end{array}$ & $\begin{array}{c}0.080^{* * *} \\
(0.004)\end{array}$ & $\begin{array}{c}0.066^{* * *} \\
(0.005)\end{array}$ & $\begin{array}{c}0.069^{* * *} \\
(0.005)\end{array}$ & $\begin{array}{c}0.062^{* * *} \\
(0.005)\end{array}$ & $\begin{array}{c}0.106^{* * *} \\
(0.010)\end{array}$ & $\begin{array}{c}0.093^{* * *} \\
(0.010)\end{array}$ & $\begin{array}{c}0.026^{* * *} \\
(0.007)\end{array}$ & $\begin{array}{c}0.008 \\
(0.007)\end{array}$ & $\begin{array}{c}0.014 \\
(0.011)\end{array}$ & $\begin{array}{c}0.072^{* * *} \\
(0.024)\end{array}$ \\
\hline Dt2 & $\begin{array}{c}0.053^{* * *} \\
(0.003)\end{array}$ & $\begin{array}{c}0.044^{* * *} \\
(0.003)\end{array}$ & $\begin{array}{c}0.066^{* * *} \\
(0.004)\end{array}$ & $\begin{array}{c}0.056^{* * *} \\
(0.005)\end{array}$ & $\begin{array}{c}0.048^{* * *} \\
(0.005)\end{array}$ & $\begin{array}{c}0.031^{* * *} \\
(0.006)\end{array}$ & $\begin{array}{c}0.079 * * * \\
(0.010)\end{array}$ & $\begin{array}{c}0.068^{* * *} \\
(0.011)\end{array}$ & $\begin{array}{c}0.005 \\
(0.008)\end{array}$ & $\begin{array}{c}0.016^{* *} \\
(0.008)\end{array}$ & $\begin{array}{c}0.014 \\
(0.011)\end{array}$ & $\begin{array}{c}0.051^{*} \\
(0.024)\end{array}$ \\
\hline DBefore & $\begin{array}{c}0.077^{* * *} * \\
(0.002)\end{array}$ & $\begin{array}{c}0.058^{* * *} \\
(0.002)\end{array}$ & $\begin{array}{c}0.082^{* * *} \\
(0.004)\end{array}$ & $\begin{array}{c}0.064^{* * *} \\
(0.004)\end{array}$ & $\begin{array}{c}0.069^{* * *} \\
(0.004)\end{array}$ & $\begin{array}{c}0.048^{* * *} \\
(0.005)\end{array}$ & $\begin{array}{c}0.095^{* * *} \\
(0.008)\end{array}$ & $\begin{array}{c}0.070^{* * *} \\
(0.009)\end{array}$ & $\begin{array}{c}0.002 \\
(0.007)\end{array}$ & $\begin{array}{c}0.025^{* * *} \\
(0.007)\end{array}$ & $\begin{array}{l}0.018^{*} \\
(0.010)\end{array}$ & $\begin{array}{l}-0.015 \\
(0.021)\end{array}$ \\
\hline DLeast & $\begin{array}{c}0.117^{* * *} \\
(0.015)\end{array}$ & $\begin{array}{c}0.133^{* * *} \\
(0.015)\end{array}$ & $\begin{array}{c}0.089^{* * *} * \\
(0.030)\end{array}$ & $\begin{array}{c}0.118^{* * *} \\
(0.030)\end{array}$ & $\begin{array}{l}0.056^{*} \\
(0.033)\end{array}$ & $\begin{array}{c}0.070 * * \\
(0.032)\end{array}$ & $\begin{array}{c}0.106 * * \\
(0.065)\end{array}$ & $\begin{array}{c}0.154^{* *} \\
(0.064)\end{array}$ & $\begin{array}{c}0.282^{* * *} \\
(0.028)\end{array}$ & $\begin{array}{c}0.333^{* * *} \\
(0.038)\end{array}$ & $\begin{array}{c}0.318^{* * *} \\
(0.047)\end{array}$ & $\begin{array}{c}0.341^{* * *} \\
(0.109)\end{array}$ \\
\hline DPlant t0 & & $\begin{array}{c}0.017^{* * *} \\
(0.004)\end{array}$ & & $\begin{array}{c}0.025^{* * *} \\
(0.006)\end{array}$ & & $\begin{array}{c}0.006 \\
(0.007)\end{array}$ & & $\begin{array}{c}0.005 \\
(0.012)\end{array}$ & & & & \\
\hline DPlant $\mathrm{t} 1$ & & $\begin{array}{c}0.021^{* * *} \\
(0.004)\end{array}$ & & $\begin{array}{c}0.017^{* *} \\
(0.006)\end{array}$ & & $\begin{array}{c}0.015^{* *} \\
(0.008)\end{array}$ & & $\begin{array}{c}0.014 \\
(0.013)\end{array}$ & & & & \\
\hline DPlant t2 & & $\begin{array}{c}0.024^{* * *} \\
(0.004)\end{array}$ & & $\begin{array}{c}0.016^{* *} \\
(0.006)\end{array}$ & & $\begin{array}{c}0.004 \\
(0.007)\end{array}$ & & $\begin{array}{c}0.020 \\
(0.013)\end{array}$ & & & & \\
\hline Year dummies & Yes & Yes & Yes & Yes & Yes & Yes & Yes & Yes & Yes & Yes & Yes & Yes \\
\hline Observations & 84106 & 70248 & 33862 & 28366 & 21945 & 18229 & 8147 & 6686 & 9944 & 10114 & 4412 & 1409 \\
\hline $\mathrm{R} 2$ overall & 0.010 & 0.012 & 0.010 & 0.011 & 0.005 & 0.004 & 0.009 & 0.010 & 0.026 & 0.026 & 0.025 & 0.011 \\
\hline
\end{tabular}

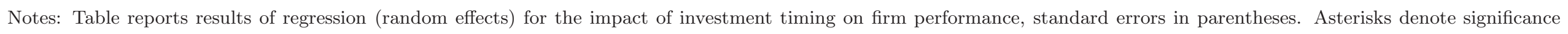
levels (***: $\mathrm{p}<1 \%$; **: $\mathrm{p}<\% 5 \%$; : $\mathrm{p}<10 \%$ ). 
Table 19: Effect of Investment on Employment Growth by Pavitt sector (Table 9)

\begin{tabular}{|c|c|c|c|c|c|c|c|c|c|c|c|c|}
\hline \multirow{3}{*}{$\begin{array}{l}\text { Gr Empl } \\
\text { Dt0 }\end{array}$} & \multicolumn{8}{|c|}{ France } & \multicolumn{4}{|c|}{ Italy } \\
\hline & \multicolumn{2}{|c|}{$\begin{array}{c}\text { Supplier } \\
\text { Dominated } \\
\end{array}$} & \multicolumn{2}{|c|}{$\begin{array}{c}\text { Scale } \\
\text { Intensive }\end{array}$} & \multicolumn{2}{|c|}{$\begin{array}{c}\text { Specialized } \\
\text { Suppliers } \\
\end{array}$} & \multicolumn{2}{|c|}{$\begin{array}{c}\text { Science } \\
\text { Based }\end{array}$} & \multirow{2}{*}{ 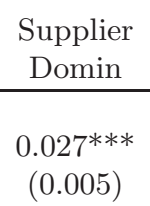 } & \multirow{2}{*}{$\begin{array}{c}\text { Scale } \\
\text { Inten }\end{array}$} & \multirow{2}{*}{$\begin{array}{c}\text { Special } \\
\text { Suppl }\end{array}$} & \multirow{2}{*}{$\begin{array}{c}\begin{array}{c}\text { Science } \\
\text { Based }\end{array} \\
0.041^{* * *} \\
(0.014)\end{array}$} \\
\hline & $\begin{array}{c}0.044^{* * *} \\
(0.002)\end{array}$ & $\begin{array}{c}0.038^{* * *} \\
(0.002)\end{array}$ & $\begin{array}{c}0.045^{* * *} \\
(0.003)\end{array}$ & $\begin{array}{c}0.044^{* * *} \\
(0.003)\end{array}$ & $\begin{array}{c}0.039^{* * *} \\
(0.004)\end{array}$ & $\begin{array}{c}0.035^{* * *} \\
(0.004)\end{array}$ & $\begin{array}{c}0.078^{* * *} \\
(0.007)\end{array}$ & $\begin{array}{c}0.070^{* * *} \\
(0.007)\end{array}$ & & & & \\
\hline Dt1 & $\begin{array}{c}0.013^{* * *} \\
(0.002)\end{array}$ & $\begin{array}{c}0.010^{* * *} \\
(0.002)\end{array}$ & $\begin{array}{c}0.011^{* * *} \\
(0.003)\end{array}$ & $\begin{array}{c}0.011^{* * *} \\
(0.004)\end{array}$ & $\begin{array}{c}0.005 \\
(0.004)\end{array}$ & $\begin{array}{c}0.002 \\
(0.004)\end{array}$ & $\begin{array}{c}0.007 \\
(0.007)\end{array}$ & $\begin{array}{c}0.004 \\
(0.008)\end{array}$ & $\begin{array}{c}0.006 \\
(0.005)\end{array}$ & $\begin{array}{c}0.011^{* *} \\
(0.005)\end{array}$ & $\begin{array}{l}0.013^{*} \\
(0.007)\end{array}$ & $\begin{array}{c}0.003 \\
(0.015)\end{array}$ \\
\hline Dt2 & $\begin{array}{c}-0.001 \\
(0.002)\end{array}$ & $\begin{array}{c}-0.002 \\
(0.002)\end{array}$ & $\begin{array}{c}-0.002 \\
(0.003)\end{array}$ & $\begin{array}{l}-0.001 \\
(0.004)\end{array}$ & $\begin{array}{c}-0.014^{* * *} \\
(0.004)\end{array}$ & $\begin{array}{c}-0.016^{* * *} \\
(0.004)\end{array}$ & $\begin{array}{l}-0.002 \\
(0.007)\end{array}$ & $\begin{array}{l}-0.006 \\
(0.008)\end{array}$ & $\begin{array}{l}-0.004 \\
(0.005)\end{array}$ & $\begin{array}{c}0.005 \\
(0.006)\end{array}$ & $\begin{array}{c}0.007 \\
(0.007)\end{array}$ & $\begin{array}{l}-0.009 \\
(0.015)\end{array}$ \\
\hline DBefore & $\begin{array}{c}-0.007^{* * *} \\
(0.002)\end{array}$ & $\begin{array}{c}-0.004^{* *} \\
(0.002)\end{array}$ & $\begin{array}{c}-0.012^{* * *} \\
(0.002)\end{array}$ & $\begin{array}{c}-0.008^{* * *} \\
(0.003)\end{array}$ & $\begin{array}{c}-0.009^{* * *} \\
(0.003)\end{array}$ & $\begin{array}{c}-0.009^{* * *} \\
(0.003)\end{array}$ & $\begin{array}{c}-0.017^{* *} \\
(0.005)\end{array}$ & $\begin{array}{c}-0.014^{* *} \\
(0.006)\end{array}$ & $\begin{array}{c}-0.011^{* * *} \\
(0.004)\end{array}$ & $\begin{array}{l}-0.003 \\
(0.004)\end{array}$ & $\begin{array}{c}-0.012^{* *} \\
(0.005)\end{array}$ & $\begin{array}{l}-0.006 \\
(0.012)\end{array}$ \\
\hline DLeast & $\begin{array}{c}0.024^{* * *} \\
(0.002)\end{array}$ & $\begin{array}{c}0.024^{* * *} \\
(0.002)\end{array}$ & $\begin{array}{c}0.021^{* * *} \\
(0.003)\end{array}$ & $\begin{array}{c}0.018^{* * *} \\
(0.003)\end{array}$ & $\begin{array}{c}0.018^{* * *} \\
(0.003)\end{array}$ & $\begin{array}{c}0.021^{* * *} \\
(0.004)\end{array}$ & $\begin{array}{c}0.020^{* * *} \\
(0.006)\end{array}$ & $\begin{array}{c}0.021^{* * *} \\
(0.007)\end{array}$ & $\begin{array}{c}0.009^{*} \\
(0.005)\end{array}$ & $\begin{array}{c}0.008^{*} \\
(0.004)\end{array}$ & $\begin{array}{c}0.002 \\
(0.006)\end{array}$ & $\begin{array}{c}0.013 \\
(0.014)\end{array}$ \\
\hline DPlant t0 & & $\begin{array}{c}0.018^{* * *} \\
(0.003)\end{array}$ & & $\begin{array}{c}0.014^{* * *} \\
(0.005)\end{array}$ & & $\begin{array}{c}0.017^{* * *} \\
(0.005)\end{array}$ & & $\begin{array}{c}0.011 \\
(0.009)\end{array}$ & & & & \\
\hline DPlant t1 & & $\begin{array}{c}0.004 \\
(0.003)\end{array}$ & & $\begin{array}{r}-0.005 \\
(0.005)\end{array}$ & & $\begin{array}{c}0.012^{* *} \\
(0.005)\end{array}$ & & $\begin{array}{c}0.002 \\
(0.009)\end{array}$ & & & & \\
\hline DPlant t2 & & $\begin{array}{c}0.002 \\
(0.004)\end{array}$ & & $\begin{array}{c}0.000 \\
(0.005)\end{array}$ & & $\begin{array}{c}0.004 \\
(0.006)\end{array}$ & & $\begin{array}{c}0.003 \\
(0.010)\end{array}$ & & & & \\
\hline Year dummies & Yes & Yes & Yes & Yes & Yes & Yes & Yes & Yes & Yes & Yes & Yes & Yes \\
\hline Observations & 84101 & 70243 & 33845 & 28353 & 21945 & 18229 & 8145 & 6685 & 9944 & 10114 & 4412 & 1409 \\
\hline $\mathrm{R} 2$ overall & 0.024 & 0.022 & 0.027 & 0.025 & 0.026 & 0.027 & 0.051 & 0.048 & 0.011 & 0.007 & 0.014 & 0.016 \\
\hline
\end{tabular}

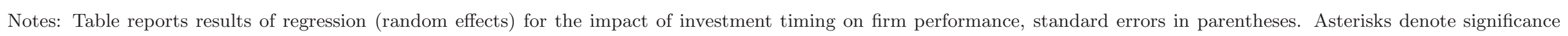
levels (***: $\mathrm{p}<1 \%$; **: $\mathrm{p}<\% 5 \%$; : $\mathrm{p}<10 \%$ ). 


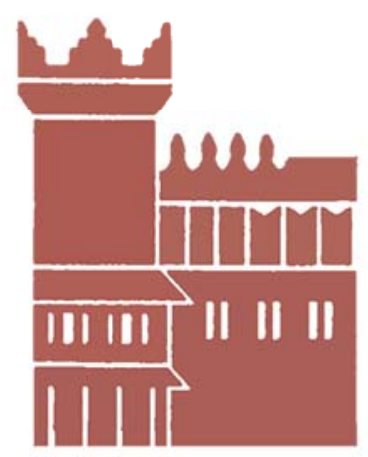

Alma Mater Studiorum - Università di Bologna DEPARTMENT OF ECONOMICS

Strada Maggiore 45

40125 Bologna - Italy

Tel. +39051 2092604

Fax +390512092664

http://www.dse.unibo.it 